\title{
A ORGANIZAÇÃO INDUSTRIAL DÄ MOAGEM DE TRIGO NO BRASIL
}

\author{
LUIS ALBERTO FERREIRA GARCIA \\ Economista
}

Orientador: Prof. Dr. EVARISTO MARZABAL NEVES.

\begin{abstract}
Dissertação apresentada à Escola Superior de Agricultura "Luiz de Queiroz", da Universidade de São Paulo, para obtenção do título de Mestre em Ciências, Área: Economia Aplicada.
\end{abstract}

\author{
P I R A C I C A B A \\ Estado de São Paulo - Brasil \\ Fevereiro - 1997
}


Dados Internacionais de Catalogação na Publicação (CIP) DIVISÃO DE BIBLIOTECA E DOCUMENTAÇÃO - Campus "Luiz de Queiroz"/USP

\section{Garcia, Luis Alberto Ferreira}

A organização industrial da moagem de trigo no Brasil / Luis Alberto Ferreira Garcia. - Piracicaba, 1997.

158 p. : il.

Dissertação (mestrado) - - Escola Superior de Agricultura Luiz de Queiroz, 1997. Bibliografia.

1. Moinho - Modernização 2. Organização industrial 3. Trigo - Produto derivado

CDD 338.6

338.47664722 


\section{A ORGANIZAÇÃO INDUSTRIAL DA MOAGEM DE TRIGO NO BRASIL}

LUÍS ALBERTO FERREIRA GARCIA

Aprovada em: 15.04 .1997

Comissão julgadora:

Prof. Dr. Evaristo Marzabal Neves

ESALQ/USP

Prof. Dr. Pedro Valentim Marques

ESALQ/USP

Profa. Dra Elizabeth Maria Mercier Querido Farina

FEA/USP

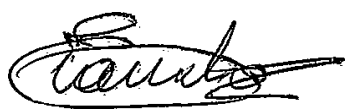

Prof. Dr. Evaristo Marzabal Neves Orientador 


\section{DEDICO}

A Deus, pela vida e pelo privilégio de amar e ser amado.

Ao povo do Oeste do Paraná e a sua maior conquista: a UNIOESTE

Ao meu pai Hélio (in memorian) e a minha mãe Olga, pelos exemplos de vida, amor, carinho, honestidade e caráter.

Aos meus padrinhos, Jaime e Neusa, e aos meus irmãos, Edson, Paulo, Cristina, Déti, Kátia e Tais, que mesmo longe sempre fizeram-se presentes em meu coração.

Aos meus cunhados e cunhadas e, em particular, ao Chico, Vilmar e Leandro que, mais que amigos, são meus irmãos.

A todos os meus sobrinhos e a minha irmã caçula Taís, para que o esforço dedicado à elaboração deste trabalho sirva de estímulo e exemplo.

Aos meus grandes amigos Francisco, Eziquiel e Ronaldo e as minhas queridas amigas, Estela Reyes e Luciane pelas provas de carinho, amizade e companheirismo.

E de forma toda especial a minha esposa Selemara, meu grande e único amor. 


\section{AGRADECIMENTOS}

Trata-se de uma tarefa dificil relacionar as pessoas e instituições que contribuíram para a elaboração deste trabalho, sem correr o risco de cometer alguma injustiça. Porém, como na vida devemos "correr certos riscos", vou me arriscar a fazê-lo.

À Universidade Estadual do Oeste do Paraná-UNIOESTE, particularmente ao Departamento de Economia de Cascavel/PR, pela oportunidade de realização de meu mestrado.

Ao Conselho Nacional de Desenvolvimento Científico e Tecnológico, CNPq, pelo auxílio financeiro concedido.

Ao Professor Evaristo Marzabal Neves, pela orientação e amizade e aos Professores, Pedro Valentim Marques, Jóse Vicente Caixeta Filho e Elizabeth Farina, pelas importantes sugestões apresentadas ao longo da elaboração desta dissertação.

Aos professores do curso de mestrado em Economia Aplicada da ESALQ/USP, pelos ensinamentos e a todos os funcionários do Departamento, pela atenção sempre dispensada.

A Luciane e Angélica, funcionárias da biblioteca setorial, pela paciente colaboração e amizade.

Aos colegas de Mestrado e, em especial, aos meus grandes amigos, Francisco, Eziquiel, Nelson Mello, Estela Reyes e Valéria, pelo convívio inesquecível, amizade e companheirismo. 
Aos colegas de trabalho da UNIOESTE e, em particular, aos companheiros do Departamento de Economia, pelo apoio nesta luta que, apesar de individual, faz parte de um plano maior, de um compromisso regional de qualificação em busca da excelência no ensino superior brasileiro.

A Elaine, Luciane, Taís e Jeferson, pelo auxílio na coleta dos dados. Aos proprietários de moinhos que colaboraram nesta pesquisa e, em especial, ao Presidente da ABITRIGO, Sr. Antenor Barros Leal, pela cedência dos dados sobre a capacidade de moagem da indústria.

A Luciane, Cristiane, Gislaine, Ana, Alice, Jéssica, Adriano e Renan, pelo apoio e ajuda inestimáveis e amizade sincera.

Ao apoio dos colegas Mário, Weimar, Tânia Lupatini, Ester, Dina, Bia, Ronaldo Bulhões, Adenise, Maurício, Celiane, Edivaldo, Nancy e Uilson Araújo.

A Selemara, esposa, amiga e companheira pelo amparo, paciência, compreensão, carinho e estímulo nos momentos de dificuldade e de mau humor. 


\section{SUMÁRIO}

Página

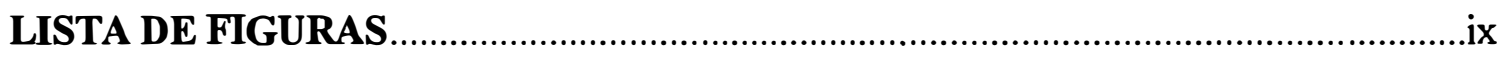

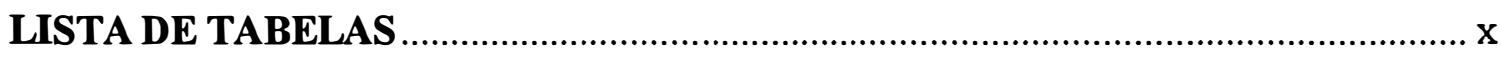

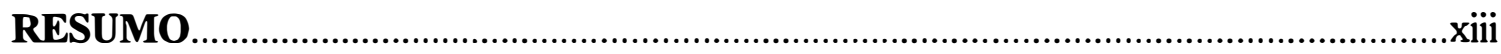

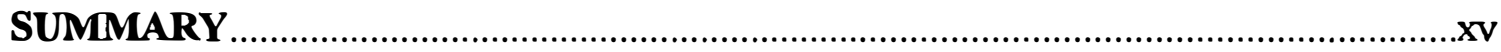

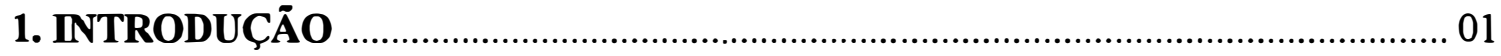

1.1 O PROBLEMA: SUA IMPORT ÂNCIA E DELIMITAÇÃO.............................. 03

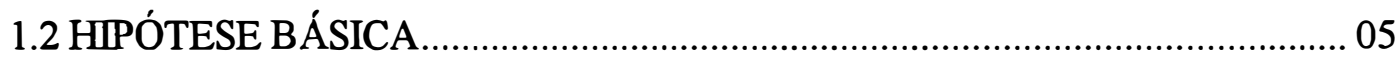

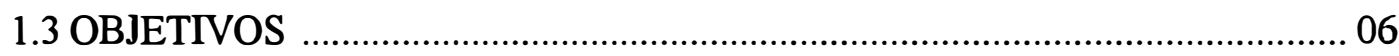

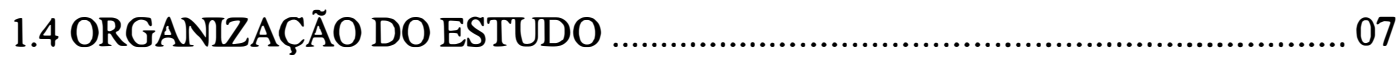

2. A CARACTERIZAÇÃo do CAI dO TRIGo E OS IMPACTOS DA REGULAÇÃO SOBRE A PRODUÇÃO E A INDÚSTRIA DE MOAGEM............... 09

2.1 CARACTERIZAÇÃO DO COMPLEXO AGROINDUSTRIAL DO TRIGO.... 09 2.2 A PRODUÇÃO DE TRIGO EM GRÃO ........................................................ 11

2.2.1 A produção mundial e as importações brasileiras de trigo............................. 11

2.2.2 Principais fornecedores brasileiros de trigo e os dispêndios do país com as

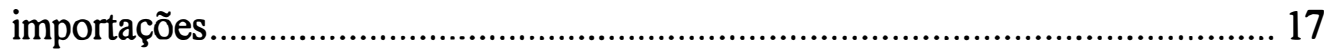

2.2.3 A produção brasileira de trigo em grão ...................................................... 22

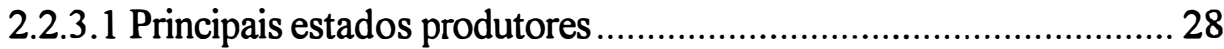

2.2.3.2 A pesquisa agronômica no Brasil .............................................. 30

2.2.4 Evolução dos preços do trigo em grão importado e dos preços pagos aos

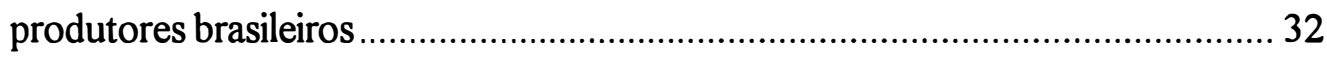

2.3 OS IMPACTOS DA REGULAÇÃO SOBRE A INDÚSTRIA DE MOAGEM . 34

2.3.1 A subvenção a produção e ao consumo através do sistema de preços........ 35 2.3.2 O funcionamento dos moinhos no mercado regulado e os impactos desta regulação sobre o setor 
3. REFERENCIAL TEÓRICO E METODOLÓGICO 47

3.1 A TEORIA DA ORGANIZAÇÃO INDUSTRIAL ........................................... 47

3.1.1 Modelo de Estrutura-Conduta-Desempenho ……………………............ 49

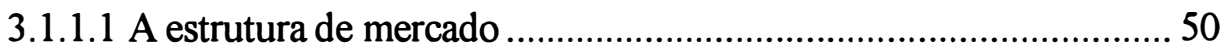

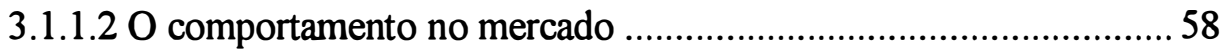

3.1.1.3 Desempenho das empresas no mercado ......................................... 62

3.1.2 A teoria da OI na análise do crescimento das firmas e indústrias ................ 63

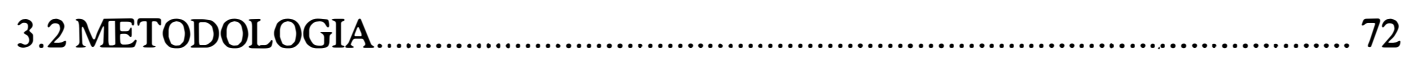

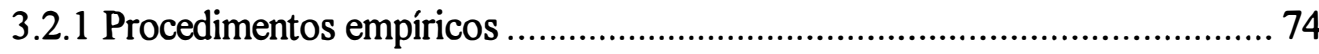

4. A INDÚSTRIA DE MOAGEM DE TRIGO NA ECONOMIA DE MERCADO .... 76

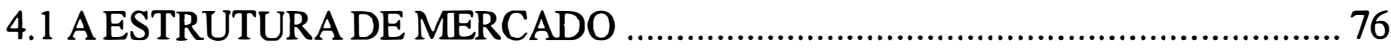

4.1.1 Evolução do número absoluto de moinhos e suas capacidades instaladas de produção, por zonas de consumo …………………….................................... 77

4.1.2 Distribuição territorial do parque moageiro brasileiro .................................. 79

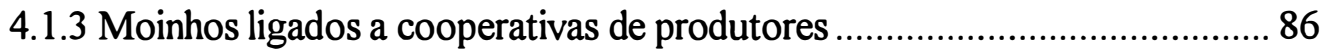

4.1.4 Evolução dos índices de concentração técnica na indústria de moagem..... 87

4.1.5 A concentração econômica na indústria de moagem.................................... 90

4.1.6 O grau de ociosidade da indústria e o potencial de crescimento da demanda

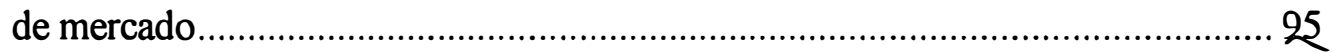

4.1.7 Segmentação do mercado consumidor e diferenciação de produtos ........... 98

4.1.8 Estratégias de aquisição de matéria-prima............................................... 100

4.2 O DESEMPENHO DA INDÚSTRIA DE MOAGEM ..................................... 102

4.3 ANÁLISE INTERPRETATIVA DA PESQUISA REALIZADA JUNTO ÀS EMPRESAS MOAGEIRAS BRASILEIRAS ….................................................... 108

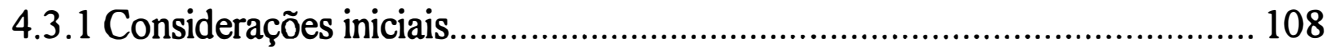

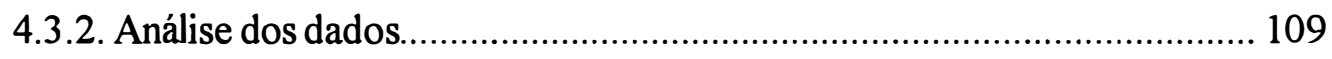

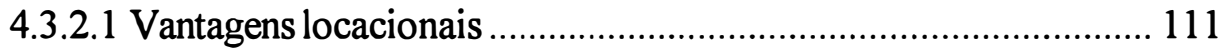

4.3.2.2 Grau de utilização, ampliações e projetos de ampliação da

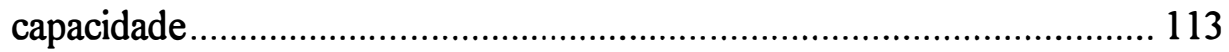

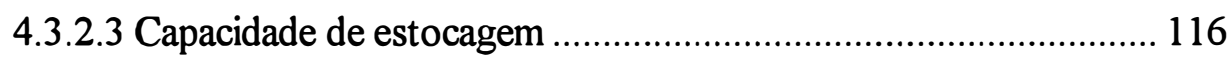


4.3.2.4 Número de funcionários e qualificação da mão-de-obra 118

4.3.2.5 Investimentos em modernização, renovação ou ampliação do setor de moagem e de armazenagem do grão 119

4.3.2.6 Estratégias de aquisição de matéria-prima. 121

4.3.2.7 Abrangência do mercado e estratégias comerciais. 123

CONCLUSÕES 127

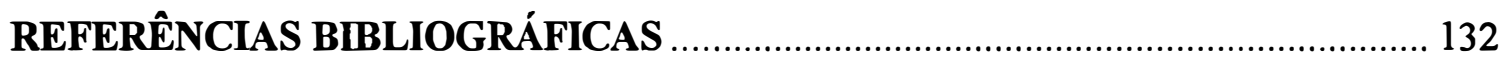

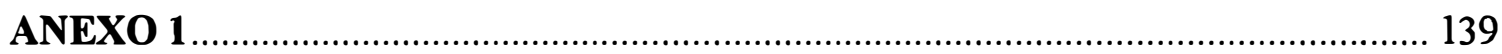

ANEXO 2

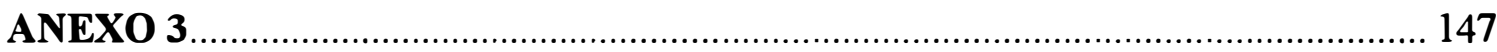

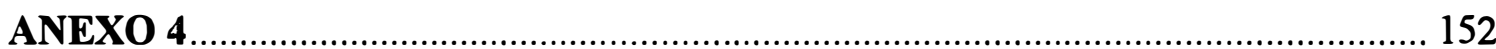

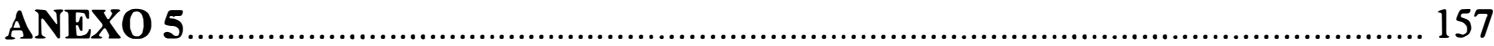

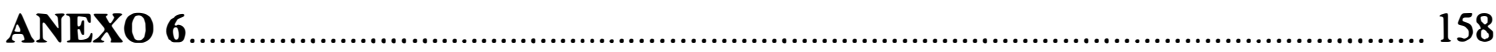




\section{LISTA DE FIGURAS}

Página

FIGURA 2.1 - O complexo agroindustrial tritícola brasileiro. 10 


\section{LISTA DE TABELAS}

Página

TABELA 2.1 - Trigo principais países produtores, 1990/91 a 1995/96 ............................. 13

TABELA 2.2 - Trigo principais países exportadores, 1990/91 a 1995/96............................ 14

TABELA 2.3 - Trigo principais países importadores, 1990/91 a 1995/96. ......................... 15

TABELA 2.4 - Oferta e demanda mundial de trigo, 1990/91 a 1995/96 ........................... 17

TABELA 2.5 - Importações brasileiras de trigo em grão, por país de origem; 1991/95. ..... 18

TABELA 2.6 - Importação brasileira de farinha de trigo, por país de origem; 1991/95 ...... 21

TABELA 2.7 - Dispêndios do Brasil com importações de trigo em grão e farinha de trigo,

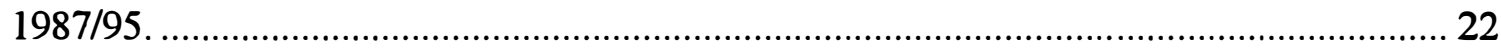

TABELA 2.8 - Área colhida, produção e produtividade da cultura de trigo no Brasil,

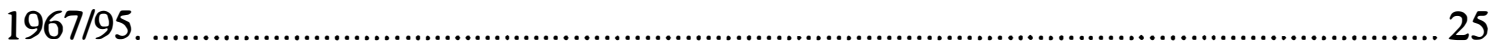

TABELA 2.9 - Principais estados produtores, evolução da área e produção........................ 29

TABELA 2.10 - Preços nominais pagos aos triticultores nacionais e preços de importação de trigo, Brasil; 1967/95. 33

TABELA 2.11 - Evolução da concentração técnica na indústria brasileira de moagem de trigo, segundo a capacidade real, por zona de consumo. 44

TABELA 2.12 - Principais grupos econômicos no setor de moagem de trigo no Brasil, 1987.

TABELA 3.1 - Estrutura de análise e possíveis variáveis para avaliação de mercados......... 51

TABELA 3.2 - Distribuição hipotética de "n" empresas num mercado................................. 54

TABELA 4.1 Capacidade de moagem instalada dos moinhos de acordo com as 8 zonas de consumo no Brasil - 1987 e 1996 78

TABELA 4.2 Localização do parque moageiro nacional e capacidade de moagem instalada por regiões e estados do Brasil, 1996 80 
TABELA 4.3 Distribuição absoluta dos moinhos brasileiros por classe de capacidade de moagem, segundo as zonas de consumo, 1996 81

TABELA 4.4 Distribuição absoluta dos moinhos brasileiros por classe de capacidade de moagem, segundo as regiões brasileiras, 1996 82

TABELA 4.5 Distribuição absoluta e relativa dos moinhos de trigo por classe de capacidade de moagem, Brasil - 1987. 84

TABELA 4.6 Distribuição absoluta e relativa dos moinhos de trigo por classe de capacidade de moagem, Brasil -1996.

TABELA 4.7 Número de moinhos ligados a cooperativas de produtores e capacidade total de moagem por estado - Brasil, 1996. 86

TABELA 4.8 Evolução da concentração técnica na indústria de moagem de trigo, segundo a capacidade real em 1987 e capacidade instalada em 1996, por zona de consumo 88

TABELA 4.9 Principais grupos econômicos na moagem de trigo - Brasil, 1996 92

TABELA 4.10 Balanço de oferta e de demanda de trigo no Brasil - 1987/88 a 1996/97 $(1000 \mathrm{t})$ 96

TABELA 4.11 Capacidade ociosa do parque moageiro nacional, por regiões - Brasil, 1996 .

TABELA 4.12 Importação de produtos derivados do trigo, Brasil - 1990 e 1993 a 1995 (toneladas) 105

TABELA 4.13 Exportação de trigo em grão e produtos derivados, Brasil - 1992 a 1996 (toneladas). 105

TABELA 4.14 Farinha de trigo: preço médio de importação e exportação, 1992 a 1996 (US\$/k - FOB) 106

TABELA 4.15 Preço de venda de farinha de trigo comum no estado do Paraná, varejo e atacado, 1991 a 1996. (US\$/k) 106

TABELA 4.16 Preço de venda de farinha de trigo especial no estado do Paraná, varejo e atacado, 1991 a 1996. (US\$/k) 107

TABELA 4.17 Preços no mercado varejista de São Paulo de produtos derivados de trigo e preço de farelo de trigo, 1991 a 1995. (média anual em US\$) 107 
TABELA 4.18 Número de moinhos pesquisados, por classes de moagem e percentual em relação ao total, 1996 110

TABELA 4.19 Número de moinhos próximos a regiões produtoras, 1996 111

TABELA 4.20 Número de moinhos próximos a grandes centros consumidores, 1996 ..... 112

TABELA 4.21 Moinhos próximos a portos marítimos e percentual de utilização do trigo importado, 1996

TABELA 4.22 Capacidade de moagem instalada real, percentual de cada moinho sobre a capacidade total e nível de capacidade ociosa, por classe de moagem, 1996. 114

TABELA 4.23 Ampliações realizadas de 1990 a 1996 e projetos de ampliações a curto e médio prazos dos moinhos 115

TABELA 4.24 Capacidade estática de estocagem de trigo em grão, de farinha de trigo e capacidade de moagem instalada, 1996. 117

TABELA 4.25 Total de funcionários, por classe de moagem, uso de mão-de-obra familiar e quantidade de moinhos que fizeram investimentos em qualificação de mão-de-obra (1990 a 1996). 118

TABELA 4.26 Número de moinhos que investiram no setor de moagem e armazenamento de trigo, 1996.

TABELA 4.27 Processo de descarregamento do trigo em grão e etapa de ensacamento e ensilagem de derivados, 1996

TABELA 4.28 Número de moinhos que realizam contratos antecipados de compra de trigo, 1996

TABELA 4.29 Abrangência do mercado dos moinhos, 1996 124

TABELA 4.30 Número de moinhos associados à indústria de transformação, 1996 126 


\title{
A ORGANIZAÇÃO INDUSTRIAL DA MOAGEM DE TRIGO NO BRASIL
}

\author{
Autor: Luís Alberto Ferreira Garcia \\ Orientador: Prof. Dr. Evaristo Marzabal Neves.
}

\section{RESUMO}

Este trabalho analisa, através de alguns indicadores de organização industrial, a estrutura do setor de moagem de trigo e o comportamento de suas empresas, especialmente no tocante as suas estratégias de crescimento e competição no mercado desregulado atual.

$\mathrm{O}$ trabalho inclui a aplicação de um questionário junto aos moinhos brasileiros, a fim de verificar alguns aspectos importantes da estrutura, conduta e desempenho das empresas na indústria, tais como: suas vantagens locacionais, os investimentos realizados em modernização do setor de moagem e armazenagem do grão, estratégias de aquisição de matéria-prima e de diferenciação do produto.

Os indicadores, apontam uma redução no nível de concentração técnica do setor de moagem, nos últimos seis anos, devido à entrada de novas unidades de produção no setor e ao aumento da capacidade de moagem de algumas unidades em operação. Estes dois fatores, porém, têm contribuído para aumentar o nível de capacidade ociosa da indústria, principalmente nas pequenas unidades de produção, que não se beneficiam das economias de operação de uma grande planta. 
Por outro lado, a concentração econômica do setor tem aumentado, principalmente devido ao intenso processo de aquisições de moinhos por parte de alguns conglomerados do setor, que buscam, desta forma, novos escoadouros para a sua produção.

A disputa pela venda de derivados da moagem de trigo e pela aquisição da matériaprima no mercado externo e interno tem acirrado a concorrência e exigido profundas modificações nas atitudes comerciais e gerenciais das empresas. Constata-se, neste particular, importantes vantagens em favor das grandes unidades, principalmente aquelas que pertencem ou têm vinculação aos grandes grupos econômicos. Dentre estas vantagens inclui-se a oferta de farinha diferenciada, atendendo uma crescente exigência das indústrias de transformação, em decorrência do privilegiado acesso ao trigo importado, além de melhores condições de preço e prazo para pagamento, haja vista suas maiores disponibilidades de capital de giro e crédito.

Conclui-se que o ambiente de livre mercado onde se inseriu a indústria de moagem de trigo no Brasil, após a desregulação total do setor ocorrida em 1990, abriu novas oportunidades às empresas, principalmente através de ações integradas com as indústrias de transformação de derivados da farinha de trigo, as quais defrontam-se com o desafio de atender às demandas de um consumidor cada vez mais exigente. 


\section{THE INDUSTRIAL ORGANIZATION OF WHEAT MILLING IN BRAZIL}

Author: Luís Alberto Ferreira Garcia Adviser: Prof. Dr. Evaristo Marzabal Neves

\section{SUMMARY}

This paper, by means of some of the Industrial Organization indicators, analyses the structure of the wheat milling sector and the behaviour of the firms comprising it, specially with regard to its growth and competitive strategies in the current deregulated market.

The paper includes the application of a questionnaire among Brazilian millers, in order to check some important aspects of the structure, conduct and performance of firms in the industry, such as: The advantages gained fron their locations, investments made in modenization of the milling and grain storage sectors, raw material acquisition strategies and product diferentiation.

The indicators point to a reduction in the level of technical concentration in the milling sector over the last six years, due to the entry of new production units in the sector and to the increase in milling capacity of some of the units in operation. These two factors, however, have contributed to increasing the level of idle capacity in the industry, mainly in the small production units, which are do not benefit from the operational savings enjoyed by a large plant. 
On the other hand, the economic concentration of the sector has increased, mainly due to the intense process of acquisition of mills on the part of some conglomerates in the sector, who in this way, see new outlets their production.

The dispute for the sale of wheat milling by-products and for the acquisition of raw material in the external and internal markets has stimulated competition and demanded profound changes in the commerial and management attitudes of firms. Important advantages have been found in this regard, in favour of large units, mainly those who belong to or have ties with large economic groups. Among these advantages are included the offer of differentiated flour which, due to the priveliged access to imported wheat, meets the growing demands of transformation industries, apart from being able to offer better price and payment conditions, due to having a greater availability of working capital and credit.

It is concluded that the environment of the free market, where the wheat milling industry in Brazil has been included after the total deregulation of the sector which ocurred in 1990 , has opened new opportunities to the companies, mainly through integrated action with the industries transforming wheat flour derivatives, which are faced with the challenge of meeting the requirements of an increasingly demanding consumer. 


\section{INTRODUÇÃO}

O hábito do consumo de derivados de trigo foi introdurido no Brasil no período colonial e ampliou-se, principalmente, com o processo de urbanização ocorrido no final do século passado e o surgimento das grandes cidades brasileiras.

Há registros de que a participação do Estado no setor tritícola brasileiro é muito antiga, porém, é a partir de 1930, com o desenvolvimento industrial e o conseqüente crescimento do mercado interno, que suas ações se intensificam. Dada a importância e o peso que o trigo e seus derivados passaram a ter nos orçamentos familiares, assim como o impacto das importações do cereal sobre o balanço de pagamentos do país, o governo interfere no setor a fim de incentivar o cultivo do grão nacional que não se desenvolvia por não conseguir concorrer com o trigo importado, geralmente subsidiado na origem. Iniciada essa intervenção, o governo paulatinamente a amplia, especialmente a partir da década de cinqüenta, na tentativa de corrigir distorções que, muitas vezes, a sua própria atuação provocava.

A diferença de preços entre o trigo nacional e o importado e a atuação do Estado, que tentava incentivar a produção obrigando as indústrias a moerem uma cota do grão produzido internamente, gerou distorções e fraudes no setor. A fim de eliminá-las, o governo brasileiro amplia a sua intervenção sobre o mercado de trigo.

Assim, em 1951, cria-se o monopólio de importação pelo Estado e aprimora-se o sistema de cotas aos moinhos; em 1962, o Banco do Brasil passa a adquirir a safra interna de trigo e, finalmente, em 1967, há a regulação final e total do setor através do Decreto-Lei/210. 
A regulamentação da comercialização do trigo em grão pelo Governo e o sistema de cotas aos moinhos permitiram a fácil operacionalização de uma política de subsídios de preços ao setor. Porém, no final dos anos oitenta, o trigo já não vinha recebendo a mesma atenção governamental. Isso veio culminar em uma nova orientação para a industrialização do trigo, estabelecida na Lei n ${ }^{\circ} 8.096$ de 21 de novembro de 1990, que revogou o Decreto-Lei número 210/67, desregulamentando a comercialização e a industrialização do cereal.

Segundo Vital e Sampaio (1993, p.365), a aplicação desta lei implicou ainda: (a) fixação de preços mínimos de garantia; (b) acesso dos produtores ao sistema de empréstimos e aquisições do governo federal (EGF e AGF); (c) manutenção, por tempo determinado, do monopólio do governo nas importações de trigo; (d) manutenção pelo governo dos estoques estratégicos daquele cereal para dois meses de consumo e, (e) redução gradual da tarifa de importação. Para os autores, no triênio 1990/92,

"a privatização da comercialização do trigo e respectivo processo de ajuste do setor, juntamente com a retirada do subsidio ao consumo, somados à escassez de recursos do crédito rural para custeio da produção, indexação total ou parcial dos empréstimos, cobrança de altas taxas de juros reais, além dos baixos preços internacionais do produto, resultou na desarticulação da produção de trigo nacional, com redução significativa da área plantada e colhida" (Vital e Sampaio, 1993, p. 365).

Nada obstante, além da etapa produtiva do grão, esta urgente desregulamentação acarretou ainda importantes modificações e ajustes nos setores de comercialização e industrialização do cereal. Essas alterações de política, entretanto, não trouxeram desabastecimento ao país, sendo que o déficit no abastecimento interno tem sido suprido com o aumento das importações. Os agentes envolvidos no Complexo Agroindustrial (CAI) tritícola, destacando-se triticultores e moageiros, após um processo de reorganização interna já estão se adaptando às novas regras estabelecidas. 


\subsection{O PROBLEMA: SUA IMPORTÂNCIA E DELIMITAÇÃO}

Os governos da maioria dos países do mundo sabem da importância do trigo como alimento essencial na dieta de suas populações e, por isso, procuram interferir nesse mercado a fim de garantir o seu abastecimento. $O$ desabastecimento do produto e seus derivados e/ou a elevação abrupta de seus preços têm profundas repercussões sociais, além de agravar as contas externas de um país dependente das importações do cereal.

Essas foram, também, as principais preocupações que levaram o governo brasileiro a interferir no mercado, buscando a auto-suficiência do produto, quase alcançada em 1987. A produção do cereal e a fiscalização da indústria e comércio de farinha de trigo passam a ser, principalmente após 1944 com a criação do Serviço de Expansão do Trigo-SET, motivo de preocupação por parte de sucessivos governos brasileiros. O CAI tritícola nacional foi, a partir de então, um dos complexos que historicamente sofreu maior intervenção, culminando na sua completa regulação em 1967.

A crise fiscal do Estado serviu de justificativa para o então Presidente Fernando Collor iniciar a adoção de medidas liberalizantes durante seu governo. Desta forma, no início dos anos noventa, houve a completa desregulação do setor tritícola brasileiro, com a queda do controle estatal da comercialização e a entrada do setor privado na busca de ganhos de eficiência e de economia no processo.

Para Mendes et al. (1994), a liberalização geral do setor teve como objetivo reduzir o enorme volume de recursos dispendidos pelo governo com a aquisição do trigo nacional e importado e com o controle de todo o sistema de armazenagem e distribuição interna do trigo. Além disso, os autores destacam o fato da opção do governo Collor de fazer uma liberalização geral da economia no prazo mais rápido possível sem levar em conta, no entanto, os complexos desdobramentos que tais liberações poderiam trazer para a economia. 
Com relação ao setor tritícola uma das grandes preocupações no livre mercado foi com o risco de desabastecimento interno, caso ocorresse eventual crise internacional, tendo em vista a dependência externa do fornecimento deste alimento considerado vital para o país.

"O complexo agroindustrial (CAI) é entendido como um conjunto de atividades agricolas, industriais e comerciais, cujos encadeamentos técnico-produtivoscomerciais e financeiros geram e transformam os produtos agricolas e pecuários em produtos industriais. Os encadeamentos são tão estreitos, que a dinâmica de um segmento está associada à dinâmica dos demais integrantes do complexo" Mendes et al., 1994, p. 3).

No estudo dos CAI a agricultura passa a ser considerada sob uma perspectiva intersetorial, tanto no sentido de descrever o processo de modemização e industrialização deste setor, quanto no de fundamentar o próprio conceito de CAI. Nesta perspectiva, o desenvolvimento da agricultura passa a depender, também, da dinâmica da indústria. $\mathrm{Na}$ verdade, a abordagem do $\mathrm{CAI}$ requer que se analise todos os setores à jusante e à montante do setor produtivo e suas inter-relações.

Apesar da importância da abordagem e da análise de todo o CAI, optou-se na pesquisa por privilegiar o estudo de um setor específico do complexo e neste particular, o setor de moagem do grão. Os moinhos foram particularmente favorecidos com o completo controle do Estado no CAI tritícola. Não existia por parte das unidades moageiras a preocupação com a aquisição da matéria prima, nem em termos de quantidade, qualidade ou preços (o Governo era o único formecedor do cereal nacional e importado aos moinhos a preços administrados) e nem tampouco a preocupação com a fixação do preço de venda dos derivados da moagem (que eram também fixados pelas agências públicas). Esta sistemática lhes garantia um lucro fácil à época do mercado regulado. Nada obstante, as firmas investiram muito pouco, nesta fase, em modernização do parque moageiro. 
Farina e Zylbersztajn (1992, p. 76), destacam a importância da indústria no Complexo Agroindustrial afirmando:

"Dentro da cadeia produtiva a indústria de transformação de primeiro e segundo processamento exerce função estratégica, induzindo mudanças tecnológicas na agropecuária e, muitas vezes, também na estrutura de distribuição. Além disso tem sido responsável pela dinamização dos mercados consumidores $e$, portanto, do alargamento das possịilidades de colocação do produto primário".

A escolha de um estudo setorial, porém, não deve ser vista e analisada de forma isolada. $\mathrm{O}$ setor de moagem do grão deve ser observado como uma parte do processo de produção, que tem início no cultivo do trigo, passa pelas indústrias de transformação e termina com a comercialização dos produtos derivados.

\subsection{HIPÓTESE BÁSICA}

A hipótese básica é que a desregulação da indústria de moagem de trigo no Brasil siga a tendência verificada em outros setores que foram desregulados (como por exemplo o setor de transportes aéreos, rodoviário e de telecomunicações dos $\mathrm{EUA}^{1}$ ), ou seja, inicialmente há a entrada de novos moinhos que estavam impedidos de entrar pela barreira legal ${ }^{2}$. Em uma segunda etapa, os grandes moinhos e os grandes grupos entram em disputa pelo mercado através de concorrência via preço, segmentação de mercado, diferenciação de produtos, inovação e outras estratégias que eliminariam os menos eficientes resultando num novo processo de concentração.

\footnotetext{
'A esse respeito ver os trabalhos de Farina \& Schembri (1990), Sandler (1988), Trebing (1986) e Kahn (1988), entre outros.

${ }^{2}$ Dados da Associação Brasileira das Indústrias de Trigo (ABITRIGO) indicam a existência de 202 moinhos em 1996, sendo que em 1987 existiam 179 moinhos.
} 
No entanto, mesmo com uma nova concentração do setor, é provável que as indústrias não elevem seus preços a níveis muito acima daqueles que prevaleceriam em um mercado competitivo, tendo em vista, principalmente, a concorrência de importações decorrente da política de abertura comercial brasileira.

\subsection{OBJETIVOS}

O objetivo geral deste trabalho é analisar, através de alguns indicadores de Organização Industrial (OI), como a regulação afetou a indústria de moagem de trigo no Brasil no que diz respeito aos aspectos de estrutura, conduta e desempenho, bem como verificar o comportamento das empresas moageiras, especialmente no tocante às suas estratégias de crescimento e competição no mercado desregulado atual.

Especificamente, serão verificadas a estrutura, conduta e o desempenho da indústria de moagem no mercado regulado e atual, destacando-se os seguintes aspectos:

a) concentração técnica e econômica, bem como o número de moinhos e suas localizações no mercado;

b) número de moinhos associados a cooperativas e processadoras;

c) estratégias de aquisição de matéria-prima;

d) contratos de compra e venda antecipados;

e) comportamento dos moinhos e indústrias de derivados frente à concorrência das importações;

f) estratégias de diferenciação de produtos por parte dos moinhos e das indústrias processadoras;

g) estratégias de integração vertical dos moinhos;

h) evolução do consumo de farinha e derivados; 
i) evolução dos preços de aquisição da matéria-prima e de venda dos derivados de trigo;

j) análise das vantagens locacionais dos moinhos.

\subsection{ORGANIZAÇÃO DO ESTUDO}

Visando atingir os objetivos propostos, o presente estudo é subdividido em quatro partes básicas:

Nesta primeira parte, foram descritos o problema, sua importância e delimitação, bem como os objetivos da pesquisa.

A segunda parte do trabalho, apresenta uma descrição do Complexo Agroindustrial tritícola e considerações sobre o impacto da regulação sobre o setor produtivo do grão e a indústria de moagem. Aspectos do mercado mundial e brasileiro de trigo como, a evolução da produção, área plantada, exportações e importações são de relevância para o estudo proposto, tendo em vista ser este cereal a matéria prima básica para os moinhos. Nada obstante, apesar de importante, não é objeto do presente estudo uma análise mais aprofundada dos reflexos da regulação e posterior desregulação sobre o setor produtivo, tendo em vista não ser este o escopo do presente trabalho ${ }^{3}$. Apresenta-se, também, uma revisão dos principais trabalhos e análises do mercado regulado de trigo no Brasil, fundamentalmente Soares (1980), Silva (1989) e Mendes et al. (1994), atentando principalmente para os efeitos desta regulação sobre o setor de moagem de trigo.

A terceira parte descreve o referencial teórico e a metodologia de análise a ser utilizada no trabalho. Sintetizando as principais conclusões de autores como Bain (1958),

\footnotetext{
${ }^{3} \mathrm{~A}$ este respeito ver principalmente os trabalhos de Mendes et al. (1994) e Hubner (1996), entre outros.
} 
Stigler (1968), Sherer (1970), Marris (1971), Steindl (1976), Penrose (1979), Koch (1980), Guimarães (1987) entre outros que, indubitavelmente, agregaram conceitos chaves para a construção do corpo teórico da Organização Industrial (OI), procura-se apresentar, através de revisão bibliográfica, um esquema analítico para o estudo da estrutura conduta e desempenho das empresas moageiras brasileiras, baseado nesta teoria.

A quarta parte do trabalho apresenta os principais resultados, discussões e conclusões, com respeito ao setor de moagem de trigo, após a desregulação do mercado (1990 a 1994), destacando os aspectos relacionados com a estrutura, conduta e desempenho da indústria de moagem do grão, fundamentando-se em dados secundários e nas principais conclusões obtidas na pesquisa de campo feita junto a uma amostra de moinhos brasileiros em 1996.

A revisão de literatura, por sua vez, é apresentada ao longo de todo o trabalho. 


\section{A CARACTERIZAÇÃo do CAI do TRIgo E OS IMPACTOS DA REGULAÇÃO SOBRE A PRODUÇÃO E A INDÚSTRIA DE MOAGEM.}

\subsection{CARACTERIZAÇÃO DO COMPLEXO AGROINDUSTRIAL DO TRIGO}

O complexo agroindustrial (CAI) tritícola brasileiro, compreende a produção do trigo em grão e sua transformação e distribuição na forma de farinhas, farelo, pães, massas e biscoitos (Fig 2.1)

Pode-se verificar que os principais grupos envolvidos neste CAI, são: (a) os produtores do grão doméstico, que utilizam insumos como sementes, fertilizantes e defensivos; (b) a indústria moageira (moinhos); (c) as indústrias consumidoras de farinha e farelo (indústrias de panificação, massas, biscoitos e rações) e, (d) os consumidores finais dos derivados de trigo (consumidores de pão, macarrão, biscoitos e farinha bem como, de forma indireta, os consumidores de aves, ovos e suínos, estes últimos os consumidores indiretos de ração).

Segundo Mendes et al. (1994), o trigo em grão produzido internamente é vendido quase que exclusivamente no mercado nacional, em média, $80 \%$ para as cooperativas e $20 \%$ aos intermediários e moageiros. Parcela muito pequena da produção é utilizada pelos produtores de trigo como semente. A produção entregue às cooperativas tem por destino os moinhos e a formação de estoques do governo. 
FIGURA 2.1. O COMPLEXO AGROINDUSTRIAL TRITÍCOLA BRASILEIRO.

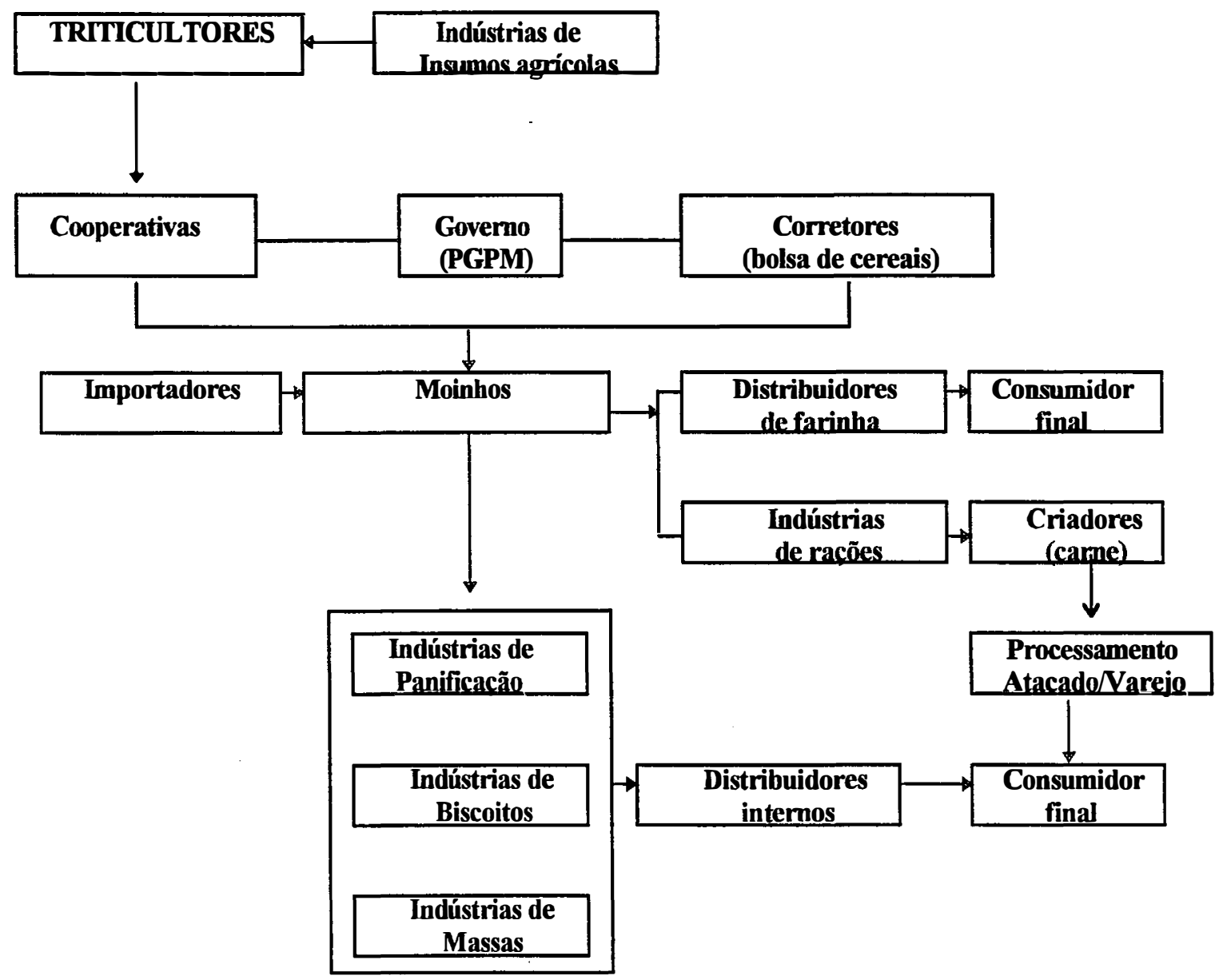

Fonte: Adaptado de Mendes et al. (1994)

Os moinhos, por sua vez, adquirem o grão diretamente das cooperativas, dos corretores (que atuam nas bolsas de cereais, comprando os estoques do governo via leilões), dos intermediários e, ainda, dos importadores. Os moageiros vendem a farinha às indústrias de transformação final (panificadoras, indústrias de massas e biscoitos) e, diretamente, aos 
distribuidores internos. $\mathrm{O}$ farelo de trigo é vendido para as indústrias de rações. A exportação de farinha de trigo passa a ser significativa a partir de $1995^{1}$.

\subsection{A PRODUÇÃO DE TRIGO EM GRÃO}

2.21 A produção mundial e as importações brasileiras de trigo

O comércio mundial de cereais e o do trigo, em particular, vem sendo há muito tempo objeto de regulação e proteção por parte dos diversos governos. Por considerarem o abastecimento interno como de importância estratégica, alguns países adotam políticas que incentivam os produtores de grão a produzirem volumes muito maiores que aqueles necessários a atender as suas demandas internas garantindo assim, a sobrevivência dos agricultores e a renda do campo sem dispêndios com importações. Os excedentes de produção passam então, a ter custos elevados para serem mantidos tornando-se necessária a sua exportação, geralmente a preços inferiores àqueles que deveriam vigorar no livre mercado e abaixo dos custos de produção.

A política agrícola comum (PAC) e a convenção de Lomé da CEE (Comunidade Econômica Européia), podem ser citadas como exemplos desse protecionismo no setor agrícola. A desestabilização dos mercados mundiais provocada pela PAC é significativa, em virtude da importância da produção e consumo europeus quando comparados aos volumes do comércio mundial dos produtos agrícolas atingidos.

\footnotetext{
'Segundo dados do DECEX, o Brasil exportou em 199218 toneladas de farinha de trigo, 2.173 ton em $1994 \mathrm{e}$
} 3.623 ton em 1996. 
Os efeitos da PAC são muito importantes, também, no mercado de trigo pois a CEE participa atualmente em média, com $15,72 \%$ da produção e $15,0 \%$ das exportações do cereal. No mesmo sentido, em maio de 1985, o governo dos EUA instituiu o Programa de Incentivo as Exportações EEP (Export Enhancement Program) que, através do fornecimento de bônus aos exportadores permitia vender algumas mercadorias em mercados específicos a preços abaixo daqueles vigentes no mercado americano. A finalidade deste instrumento era permitir aos produtores competirem em alguns mercados de commodities, com países que adotam subsídios, especialmente os da Comunidade Européia. O trigo dos EUA (terceiro maior produtor mundial do cereal) também foi amplamente amparado pelo sistema EEP.

A Tabela 2.1 permite verificar a produção e os principais produtores de trigo, a nivel mundial. China, CEE e EUA e Índia são os quatro maiores produtores, concentrando 55,86\% da produção mundial do cereal.

A Argentina, país parceiro do Brasil no Mercado Comum do Sul (MERCOSUL) e seu principal fornecedor do cereal, foi responsável, na média dos últimos 06 anos, pela produção de $1,86 \%$ de todo o trigo produzido no mundo. No entanto, com exceção do ano safra de 1994/95 quando produziu $2,16 \%$ do total mundial, esta participação foi decrescente no período, caindo de 1,85 \% em 1990/91 para 1,83 \% em 1991/92, 1,74\% em 1992/93, 1,73 \% em 1993/94 e 1,61 \% em 1995/96. Segundo o especialista argentino Ronaldo Muñoz do Boletim "Carpeta de Economia Agrícola" citado em Lorenzon (1993), a perda de participação da Argentina no total da produção mundial aconteceu tanto em função da retração do plantio como também da redução dos índices de produtividade. Na safra 1996/97 porém, este país teve um aumento significativo e, até certo ponto inesperado, de sua produção elevando-a dos 8,6 milhões no ano safra 1995/96 para 14,5 milhões de toneladas na safra seguinte. 
TABELA 2.1 Trigo principais países produtores, 1990/91 a 1995/96 (em milhões de toneladas).

\begin{tabular}{lccccccc}
\hline \hline PAÍS & $1990 / 91$ & $1991 / 92$ & $1992 / 93$ & $1993 / 94$ & $1994 / 95$ & $\begin{array}{c}1995 / 96 \\
*\end{array}$ & $\begin{array}{c}\text { Participação } \\
\text { média (\%) }\end{array}$ \\
\hline China & 98,20 & 96,00 & 101,60 & 106,40 & 99,30 & 100,00 & 18,18 \\
CEE & 84,70 & 93,70 & 87,70 & 82,90 & 84,70 & 86,40 & 15,72 \\
EUA & 74,50 & 53,90 & 67,10 & 65,20 & 63,20 & 59,50 & 11,59 \\
Índia & 49,90 & 55,10 & 55,70 & 57,20 & 59,80 & 65,50 & 10,37 \\
Rússia & 49,60 & 38,90 & 46,20 & 43,50 & 32,10 & 30,10 & 7,26 \\
Leste Europeu & 41,30 & 38,50 & 26,40 & 30,60 & 33,90 & 35,30 & 6,24 \\
Canadá & 32,10 & 31,90 & 29,90 & 27,20 & 23,10 & 25,40 & 5,12 \\
Ucrânia & 30,40 & 21,20 & 19,50 & 21,80 & 13,90 & 16,30 & 3,72 \\
Turquia & 16,00 & 16,50 & 15,50 & 16,50 & 14,70 & 15,50 & 2,88 \\
Austrália & 15,10 & 10,60 & 16,20 & 16,50 & 8,90 & 16,60 & 2,54 \\
Kazaquistão & 16,20 & 6,90 & 18,30 & 11,60 & 9,10 & 6,50 & 2,07 \\
Argentina & 10,90 & 9,90 & 9,80 & 9,70 & 11,30 & 8,60 & 1,86 \\
Outros & 69,30 & 69,00 & 67,90 & 70,20 & 69,50 & 68,80 & 12,45 \\
\hline TOTAL & 588,20 & 542,10 & 561,80 & 559,30 & 523,50 & 534,50 & 100,00 \\
\hline \hline
\end{tabular}

Fonte: Hubner (1996), com base nos dados da USDA.

* Dados preliminares

Nas safras mundiais de 1994/95 e 1995/96, observa-se uma redução da produção, em relação às safras anteriores, ocasionadas por problemas climáticos nos principais países produtores. Já no segundo semestre de 1996, a maioria dos países produtores e em especial a Argentina, voltam a colher uma grande safra do cereal.

Na Tabela 2.2 tem-se os principais exportadores mundiais de trigo. Da mesma forma que a produção, constata-se uma grande concentração da oferta de exportações de 
trigo, uma vez que apenas seis países produtores concentram 90,6\% destas exportações mundiais.

TABELA 2.2 Trigo principais países exportadores, 1990/91 a 1995/96 (em milhões de toneladas).

\begin{tabular}{lccccccc}
\hline \hline PAÍS & $1990 / 91$ & $1991 / 92$ & $1992 / 93$ & $1993 / 94$ & $1994 / 95$ & $\begin{array}{c}1995 / 96 \\
*\end{array}$ & $\begin{array}{c}\text { Participação } \\
\text { média (\%) }\end{array}$ \\
\hline EUA & 28,30 & 35,10 & 37,10 & 33,10 & 32,20 & 35,00 & 36,30 \\
CEE & 20,70 & 21,90 & 23,70 & 20,10 & 16,80 & 14,50 & 15,00 \\
Canadá & 20,50 & 24,30 & 21,70 & 18,70 & 21,50 & 18,00 & 18,70 \\
Austrália & 11,80 & 8,20 & 9,50 & 12,70 & 7,80 & 12,50 & 13,00 \\
Argentina & 4,70 & 5,70 & 7,30 & 4,50 & 7,80 & 4,80 & 5,00 \\
Kazaquistão & 5,00 & 1,40 & 5,80 & 5,50 & 4,50 & 2,50 & 2,60 \\
Outros & 10,20 & 14,20 & 7,60 & 5,50 & 7,00 & 9,10 & 9,40 \\
\hline Total & 101,20 & 110,80 & 112,70 & 100,10 & 97,60 & 96,40 & 100,00 \\
\hline \hline
\end{tabular}

Fonte: Hubner (1996), com base nos dados da USDA .

*Dados preliminares

Como já observado, estes países que possuem a supremacia da oferta, para garantir a renda do homem do campo e a independência do seu abastecimento, adotam políticas protecionistas que incentivam a sua produção a crescer mais rápido que a capacidade de absorção de seus mercados. Os excedentes elevados de produção nesses países tendem a deslocar supridores tradicionais do produto, ao serem exportados a preços inferiores aos praticados no mercado. 
De fato, da análise dos dados das Tabelas 2.1 e 2.2 pode-se notar que os EUA, terceiro maior produtor, exportou 50,95 \% de sua produção em 1994/95 e 58,82 \% em 1995/96. O Canadá, que também tem sido um importante fornecedor de trigo para o Brasil, exportou nas safras de 1994/95 e 1995/96, respectivamente, 93,07\% e 70,87 \% de sua produção e a Argentina $69,03 \%$ e 55,81 \% no mesmo período. A Austrália também se destaca como um dos principais exportadores do cereal, vendendo no mercado externo em 1995/96, 75,30 \% de sua produção.

Na Tabela 2.3, observam-se os principais países importadores de trigo. Rússia e China, que são importantes produtores são também dependentes de importações, sendo que este último país, que é o maior produtor mundial, também é o maior importador tendo, nos últimos anos, aumentado a sua demanda pelo cereal.

TABELA 2.3 Trigo principais países importadores - 1990/91 a 1995/96 (em milhões de toneladas).

\begin{tabular}{lccccccc}
\hline \hline PAÍS & $1990 / 91$ & $1991 / 92$ & $1992 / 93$ & $1993 / 94$ & $1994 / 95$ & $\begin{array}{r}1995 / 96 \\
*\end{array}$ & $\begin{array}{c}\text { Participação } \\
\text { média (\%) }\end{array}$ \\
\hline Rússia & 11,00 & 13,60 & 14,50 & 5,00 & 2,70 & 4,30 & 4,50 \\
China & 9,40 & 15,90 & 6,70 & 4,30 & 10,20 & 13,00 & 13,50 \\
Japão & 5,60 & 5,80 & 5,90 & 6,10 & 6,30 & 6,30 & 6,50 \\
Brasil & 2,80 & 5,30 & 5,80 & 5,80 & 6,60 & 6,00 & 6,20 \\
Egito & 5,70 & 5,80 & 6,00 & 5,90 & 5,80 & 6,00 & 6,20 \\
Coréia /Sul & 4,20 & 4,40 & 4,00 & 5,60 & 4,30 & 2,50 & 2,60 \\
Argélia & 4,60 & 3,70 & 3,80 & 4,80 & 4,50 & 3,30 & 3,40 \\
Outros & 57,90 & 56,30 & 66,00 & 12,60 & 57,20 & 55,00 & 57,10 \\
\hline Total & 101,20 & 110,80 & 112,70 & 100,10 & 97,60 & 96,40 & 100,00 \\
\hline \hline
\end{tabular}

Fonte: Hubner (1996), com base nos dados da USDA.

* Dados preliminares. 
O Brasil, que tem uma produção muito pequena em relação ao total produzido no mundo, foi o segundo maior importador na safra 1994/95 e aparece, atualmente, em $3^{\circ}$ lugar, ao lado do Egito, entre os principais países compradores do cereal. A participação brasileira no total das importações mundiais sofreu uma elevação considerável a partir de 1990, devido às mudanças da política para o trigo e à desregulação do setor, passando de $2,8 \%$ em 1990/91 para 6,8\% em 1994/95 e 6,2\% em 1995/96.

Ao contrário da produção e da oferta de trigo, a demanda no mercado mundial não é concentrada. Além disso, devido às políticas de subsídios às exportações, dos grandes paises exportadores, normalmente os preços são mantidos artificialmente baixos, mantendo a dependência dos importadores que ficam sujeitos ao risco constante de uma explosão de preços, embargos econômicos e desabastecimento.

Na Tabela 2.4 observa-se a oferta e demanda mundiais para as safras de 1991/92 a 1995/96. Pelos dados apresentados verifica-se que os estoques mundiais têm se reduzido significativamente nos últimos anos, caindo para uma relação de $18,1 \%$ do consumo em 1995/96.

Segundo Hubner (1996), o que contribuiu para esta redução da relação estoque/consumo mundiais foi a queda da produção nas safras 1994/95 - 1995/96, o aumento da demanda da China maior consumidor mundial, além de outros fatores conjunturais como a redução na produção mundial de soja nos últimos anos, que causou um aumento da procura por substitutos para a alimentação animal e o aparecimento da sindrome da "vaca louca" na Inglaterra, que aumentou a procura por substitutos alimentares para a carne bovina e conseqüentemente, a procura de farelo de trigo para ração. $\mathrm{O}$ reflexo destes fatores foi a disparada dos preços do trigo a nível internacional ao longo de 1996. 
Tabela 2.4 Oferta e demanda mundial de trigo, 1991/92 a 1995/96 (em milhões de toneladas).

\begin{tabular}{lccccc}
\hline \hline Discriminação & $1991 / 92$ & $1992 / 93$ & $1993 / 94$ & $1994 / 95$ & $1995 / 96$ \\
\hline Produção & 542,1 & 561,8 & 559,3 & 523,9 & 534,5 \\
Consumo & 558,5 & 549,8 & 563,2 & 548,8 & 550,9 \\
Estoque final & 132,8 & 144,8 & 140,9 & 116,0 & 99,6 \\
Estoque/Consumo (\%) & 23,8 & 26,3 & 25,0 & 21,1 & 18,1 \\
\hline \hline
\end{tabular}

Fonte: Hubner (1996), com base nos dados da USDA.

* Dados preliminares.

2.2.2 Principais fornecedores brasileiros de trigo e os dispêndios do País com as importações

Como observado, o Brasil ocupa, atualmente, a terceira posição entre os importadores de trigo, porém com volume transacionado muito inferior ao da China, principal importador.

O Brasil sempre teve vários fornecedores do grão, de modo a se beneficiar das condições específicas de cada um, tanto nos aspectos comerciais mais favoráveis, quanto dos da qualidade do trigo importado. A Argentina sempre foi tradicional fornecedora do Brasil, consolidando a sua posição no âmbito do ato de integração Brasil-Argentina, através do Protocolo ${ }^{\circ} 2$, assinado em Buenos Aires em 28/07/1986.

As importações brasileiras de trigo em grão resultam, em grande parte, de acordos entre governos (principalmente com seus parceiros do MERCOSUL); no entanto, os volumes estabelecidos não têm sido cumpridos na íntegra. 
A Tabela 2.5 mostra as importações brasileiras de trigo em grão por país de origem, de 1991 a 1995. Destacam-se a Argentina e o Canadá como principais fornecedores brasileiros. $\mathrm{O}$ volume importado dos dois países representou $81 \%$ do total das importações brasileiras do cereal em 1991, 97,07\% em 1992, 97,35\% em 1993, 84,52\% em 1994 e 98,08\% em 1995.

TABELA 2.5 - Importações brasileiras de trigo em grão, por país de origem - 1991/95 (em 1.000 toneladas).

\begin{tabular}{lccccc}
\hline \hline País & 1991 & 1992 & 1993 & 1994 & $1995^{*}$ \\
\hline Arábia Saudita & 26,50 & - & - & - & - \\
Argentina & $2.657,10$ & $3.166,30$ & $3.671,10$ & $3.586,90$ & $3.028,30$ \\
Canadá & $1.070,50$ & $1.140,70$ & $1.868,30$ & $1.572,50$ & 230.0 \\
E.U.A. & 706,90 & 129,80 & 151,00 & 15,80 & - \\
França & 29,80 & - & - & - & - \\
Turquia & 11,90 & - & - & - & - \\
Uruguai & 69,80 & - & - & - & 9,90 \\
Alemanha & - & - & - & 803,70 & 6,30 \\
Bermudas & - & - & - & 55,90 & - \\
Paraguai & - & - & - & 69,70 & 47,70 \\
\hline Total & $4.572,50$ & $4.436,80$ & $5.690,40$ & $6.140,50$ & $3.322,20$ \\
\hline \hline
\end{tabular}

Fonte: SECEX/DECEX (1996).

* Dados preliminares de janeiro a maio.

Somente da Argentina, o Brasil adquiriu $58,11 \%$ de todo o trigo em grão importado em 1991, 73,36 \% em 1992, 64,51\% em 1993, 58,41 \% em 1994 e 91,15 \% em 
1995. Pode-se notar que este país vinha perdendo espaço para o Canadá nas exportações para o Brasil de 1992 a 1994, recuperando-se, no entanto, em 1995.

Para alguns especialistas o aumento das importações de trigo canadense, por parte do Brasil, se deve ao fato de que a produção naquele país é altamente subsidiada, o que permite ao país norte americano vender o seu produto a preços inferiores aos praticados no comércio internacional. De fato o trigo canadense em 1993 chegou a ser adquirido a US\$104 a tonelada, enquanto o produto argentino era cotado, no mesmo ano, entre US\$ 125 e US\$ 130. Segundo Giovani Lorenzon (1993), este aumento das exportações de trigo do Canadá para o Brasil, gerou reclamações dos tradicionais fornecedores argentinos que alegavam prática ilegal de comércio por parte do Canadá. Porém, devido ao complexo sistema de formações de preços utilizado pelo governo canadense o subsídio era de dificil comprovação.

Além de autorizar a compra do cereal canadense o governo brasileiro também liberou em 1994 a importação de trigo alemão a US\$121 a tonelada (preços de dezembro de 1993), enquanto o trigo na bolsa de Chicago era cotado a US\$ 134 a tonelada ${ }^{2}$, o que explica o grande volume importado do país europeu.

Outro fator explicativo para o aumento das importações brasileiras a partir de 1990 foi a redução, por parte do governo, das tarifas de importação, instrumento que protegia a produção nacional em relação ao produto importado. Em 04 de fevereiro de 1991, através da portaria 73, o Ministério da Economia Fazenda e Planejamento institui uma sistemática de tarifas "ad valorem" compensatórias sobre a importação do produto e, em 07 de fevereiro de 1991, através da portaria 938, o Governo estipula as alíquotas que deveriam vigorar para os anos de 1991 a 1994 nos seguintes índices: 1991 25\%, 1992 20\%, 1993 15\% e 1994 10\%³. Além disto, para os países do Mercado Comum do Sul (MERCOSUL), dentro de uma política de desgravação progressiva, a tarifa chegou a "zero" a partir de 01 de janeiro de 1995

\footnotetext{
${ }^{2}$ Segundo Melo (1994), este preço já é rebaixado em mais ou menos $14 \%$ pela própria existência de subsídios nos países produtores do cereal.

${ }^{3}$ Informações FIPE, n 165 , São Paulo, fevereiro de 1994.
} 
Estas tarifas, no entanto, sofreram diversas alterações ao longo dos anos a partir da desregulação do mercado de trigo, ou por questões de conjuntura econômica ou no sentido de atender a interesses específicos de alguns setores do CAI. Segundo Mello (1994), elas chegaram a ser em 1990 25\%, 1991 15\%, 1993 5\% e 1993 10\%. De fato, se de um lado os produtores pressionam para a implantação de medidas que restrinjam a importação de trigo, de outro lado os moageiros reivindicam maior liberdade para a compra do cereal ao mesmo tempo em que pressionam para impedir a entrada de farinha importada. Como destaca Mendes et al. (1994, p. 60): "Como não existe uma política deliberada para o setor, as medidas acabam oscilando em tomo de pressões momentâneas de segmentos específicos".

Neste sentido é que, em março de 1994 o Governo instituiu um plano para estimular o plantio de trigo no qual constava, entre outras medidas, a elevação da tarifa de importação para mais ou menos $17 \%$ (dependia do preço do produto importado, tarifa ad valorem), apenas para o período de 15 de setembro de 1994 a 31 de janeiro de 1995. Além disso, estipulou taxação compensatória para o trigo subsidiado na origem. Fica evidente que as medidas adotadas, além de agradar aos produtores internos vinham de encontro também às expectativas dos produtores argentinos, maiores prejudicados em 1993, além dos produtores brasileiros, com a entrada de trigo subsidiado do Canadá e da Alemanha.

Comparando-se os dados das Tabelas 2.2 e 2.5, verifica-se também que a Argentina é muito dependente da demanda brasileira, vendendo em média $41 \%$ do seu trigo exportável para o Brasil aumentando este índice em 1995 para 63,08\%, com a redução do volume de trigo importado do Canadá.

Outro fato importante a se destacar é o aumento, nos últimos anos, da importação de trigo do Paraguai e do Uruguai, países parceiros do Brasil e da Argentina no Mercado Comum do Sul (MERCOSUL).

Da mesma forma que as importações de trigo em grão, as compras do Brasil de farinha de trigo no mercado externo elevaram-se consideravelmente após a liberação do 
mercado, passando de 2.540 toneladas em 1991 para 65.966,8 toneladas em 1994. O número de países fornecedores deste produto para o Brasil tem aumentado, sendo que a Argentina tem sido também, nos últimos anos, o principal fornecedor brasileiro, aproveitando-se das vantagens comerciais do Mercado Comum do Sul (Tabela 2.6).

TABELA 2.6 Importação brasileira de farinha de trigo, por país de origem - 1991/1995 (toneladas)

\begin{tabular}{lcccccc}
\hline \hline País & 1990 & 1991 & 1992 & 1993 & 1994 & 1995 \\
\hline Alemanha & 0,2 & & & & & \\
Argentina & & & $16.160,0$ & $36.948,5$ & $140.868,4$ & $65.384,7$ \\
Bélgica & & & 20,0 & 100,0 & \\
Canadá & 3,8 & 12,7 & 5,3 & 1,0 & 4,2 & \\
E.UA. & 2,2 & & & & 3,8 & 14,0 \\
Itália & 0,13 & 0,2 & & 1,5 & 21,1 & \\
Uruguai & & $2.527,0$ & $3.471,9$ & $2.246,0$ & 58,0 & 58,0 \\
Venezuela & & 0,1 & & 22,5 & 17,5 & 8,1 \\
Chile & & & & & 1,0 & 252,0 \\
Paraguai & & & & & 100,0 & 250,0 \\
\hline Total & 6,33 & $2.540,0$ & $19.637,2$ & $39.239,5$ & $141.174,0$ & $65.966,8$ \\
\hline
\end{tabular}

Fonte: SECEX/DECEX - SERPRO/SISTEMA ALICE (1996)

*Dados preliminares de janeiro a maio

Na Tabela 2.7, verifica-se os dispêndios do Brasil com as importações de trigo em grão e farinha de trigo no período de 1987 a 1995. Observa-se que, principalmente após a desregulação do mercado a partir de 1990, os gastos do Brasil com as importações do cereal foram crescentes, passando de US\$295.000.000 naquele ano para US\$ 748.739.144 em 1994, o que representa um aumento de 153,8\% neste período. Da 
mesma forma, o crescimento dos dispêndios do País com as importações de farinha de trigo foram muito elevados, passando de US\$ $499.453 \mathrm{em} 1991$ para US\$27.964.754 em 1994.

TABELA 2.7 Dispêndios do Brasil com importações de trigo em grão e farinha de trigo, 1987 a 1995 . (US\$-FOB)

\begin{tabular}{ccc}
\hline \hline Ano & $\begin{array}{c}\text { Gastos totais do Brasil com a } \\
\text { importação de trigo em grão } \\
\text { (US\$-FOB) }\end{array}$ & $\begin{array}{c}\text { Gastos totais do Brasil com a } \\
\text { importação de farinha de } \\
\text { trigo (US\$-FOB) }\end{array}$ \\
\hline 1987 & 250.000 .000 & - \\
1988 & 97.000 .000 & - \\
1989 & 211.000 .000 & - \\
1990 & 295.000 .000 & - \\
1991 & 454.563 .511 & 499.453 \\
1992 & 541.529 .782 & 4.127 .735 \\
1993 & 725.875 .032 & 8.027 .138 \\
1994 & 748.739 .144 & 27.964 .754 \\
$1995^{*}$ & 405.750 .531 & 14.820 .520 \\
\hline \hline
\end{tabular}

Fonte: Boletim do Banco Central (1987-1990)

SECEX/DECEX (1991 a 1995)

*Dados preliminares de janeiro a maio

2.2.3 A produção brasileira de trigo em grão

As normas contidas no Decreto-Lei 210/67 permitiam ao governo federal, através da Comissão de Compra de Trigo Nacional (CTRIN), estabelecer o preço de aquisição do trigo 
nacional, o preço de venda do trigo aos moinhos e controlar os preços finais dos derivados. Dessa forma, através deste sistema de subsídios e controle de preços, incentivava-se ou não a produção, garantia-se o mercado prioritariamente ao trigo nacional, assegurava-se o abastecimento do mercado interno a preços administrados e reduzia-se seus dispêndios com importações.

O governo estimulou a produção nacional via oferta de crédito, especialmente de custeio, juros subsidiados e garantia de preços aos produtores. $\mathrm{O}$ governo agia desta forma tendo em vista o custo da produção nacional ser mais elevado que a importação do cereal, geralmente subsidiado na origem.

A área cultivada sempre respondeu a esses estímulos acompanhando suas oscilações. Embora eventuais adversidades climáticas tenham frustrado algumas safras de trigo, em geral, a produção acompanhou a expansão de área.

A partir de 1967, o Brasil viveu um longo período de tendência geral de crescimento da produção. O ponto máximo foi atingido em 1987, quando o país esteve próximo da autosuficiência, produzindo $91 \%$ das suas necessidades de consumo interno. Este aumento da produção significou, no entanto, um problema para a manutenção dos subsídios governamentais, em decorrência do significativo aumento dos recursos necessários para cobrir a diferença entre os preços de compra junto aos produtores e de venda aos moinhos.

A extinção do subsídio ao consumo, ainda em 1987, a completa e abrupta desregulação do setor em setembro de 1990, além da carência geral de recursos financeiros do governo ${ }^{4}$, representaram forte desestímulo aos triticultores que passaram a reduzir drasticamente a área plantada e colheita. Não obstante, a manutenção, por um breve período

\footnotetext{
${ }^{4}$ Segundo Mendes et al (1994), esta carência de recursos para o setor produtivo do trigo é refletida pelos volumes destinados pelo governo para as operações de Aquisição do Governo Federal (AGF), Empréstimos do Governo Federal (EGF) e crédito agrícola. Dados dos autores, permitem verificar uma queda de $79 \%$ do volume das operações de EGF de 1990 a 1993, já os recursos de crédito de custeio agrícola reduziram-se em $57 \%$ no mesmo período.
} 
pós desregulação, da participação do governo na aquisição de trigo e na venda aos moinhos de seus estoques disponiveis, bem como o controle dos preços dos produtos finais como massas, pães e biscoitos, foram fatores importantes no sentido de evitar maiores desajustes do setor em um primeiro momento.

A partir da Tabela 2.8 pode-se agora, analisar a evolução da área, produção e produtividade da cultura de trigo no Brasil de 1967 a 1995. De 1967 a 1979 verifica-se um crescimento geral da área e da produção, sendo que a expansão da produção se deve muito mais ao aumento da área do que dos níveis de produtividade. Nota-se, ainda, que de $1980 \mathrm{a}$ 1984 há um declínio da produção e da área colhida e um aumento da produtividade.

Em 1985, a área e a produção voltam a crescer. Este crescimento se mantém até 1987, quando então o Brasil colhe a safra recorde de 6.099 mil toneladas de trigo e alcança o seu maior nivel de produtividade da cultura com $1.773 \mathrm{~kg}$ por hectare. Além do aumento da área, as melhorias dos niveis de produtividade, fruto da maturação do trabalho de pesquisa no desenvolvimento de variedades mais produtivas e com maior resistência a doenças, são explicativas para o aumento da produção nesta fase.

A partir de 1987 percebe-se uma redução da área plantada e uma queda da produção, que passa a ser mais significativa, ainda, a partir de 1990, ano da desregulação do mercado. De fato, após a grande safra colhida em 1987 a produção brasileira decresceu significativamente, chegando o país a colher em 1995 apenas 1.524 mil toneladas de trigo. Apesar da atenuante dos problemas climáticos ocorridos em algumas safras (principalmente em 1990), que poderia explicar a redução dos niveis de produtividade, é evidente que a desregulação abrupta do CAI tritícola, aliada à falta de uma política governamental clara para o setor, desarticulou a produção nacional. 
TABELA 2.8 Área colhida, produção e produtividade da cultura de trigo no Brasil (1967-1995).

\begin{tabular}{|c|c|c|c|}
\hline ANO & $\begin{array}{c}\text { ÁREA COLHIDA } \\
(1000 \mathrm{ha})\end{array}$ & $\begin{array}{l}\text { PRODUÇÂO } \\
(1000 \mathrm{t})\end{array}$ & $\begin{array}{l}\text { PRODUTIVIDADE } \\
(\mathrm{kg} / \mathrm{ha})\end{array}$ \\
\hline 1967 & 831 & 629 & 757 \\
\hline 1968 & 970 & 856 & 882 \\
\hline 1969 & 1.407 & $\cdot 1.374$ & 976 \\
\hline 1970 & 1.895 & 1.844 & 973 \\
\hline 1971 & 2.269 & 2.011 & 887 \\
\hline 1972 & 2320 & 983 & 424 \\
\hline 1973 & 1.839 & 2.031 & 1.104 \\
\hline 1974 & 2.471 & 2.858 & 1.156 \\
\hline 1975 & 2.931 & 1.788 & 610 \\
\hline 1976 & 3.541 & 3.220 & 909 \\
\hline 1977 & 3.153 & 2.066 & 658 \\
\hline 1978 & 2.811 & 2.691 & 956 \\
\hline 1979 & 3.830 & 2.927 & 764 \\
\hline 1980 & 3.122 & 2.702 & 865 \\
\hline 1981 & 1.919 & 2.209 & 1.151 \\
\hline 1982 & 2.825 & 1.819 & 644 \\
\hline 1983 & 1.879 & 2.237 & 1.190 \\
\hline 1984 & 1.741 & 1.956 & 1.124 \\
\hline 1985 & 2.670 & 4.323 & 1.619 \\
\hline 1986 & 3.898 & 5.638 & 1.447 \\
\hline 1987 & 3.455 & 6.127 & 1.773 \\
\hline 1988 & 3.441 & 5.847 & 1.699 \\
\hline 1989 & 3.260 & 5.479 & 1.681 \\
\hline 1990 & 2.681 & 3.304 & 1.232 \\
\hline 1991 & 1,995 & 3.078 & 1.543 \\
\hline 1992 & 1.996 & 2.739 & 1.372 \\
\hline 1993 & 1.492 & 2.098 & 1.406 \\
\hline 1994 & 1.348 & 2.138 & 1.586 \\
\hline 1995 & 1.022 & 1.524 & 1.491 \\
\hline
\end{tabular}

Fonte: De 1967 a 1986, Mendes et al (1994) com base nos dados do IBGE-Anuário Estatístico, CTRIN/B.Brasil. De 1987 a 1995, CONAB, SECEX/DECEX 
Em 1992, a liberação tardia do crédito agrícola para custeio, o problema da falta de sementes certificadas, principalmente aquelas mais utilizadas pelas indústrias de panificação, os baixos preços recebidos pelos produtores em 1991, além da desconfiança quanto ao calendário das importações do cereal, ocasionaram nova redução da área plantada e da produção, apesar da introdução neste ano, por parte do Governo, de uma tarifa compensatória ao trigo importado dos EUA vendido com subsídios do EEP (Export Enhancement Program).

Às vésperas da safra de 1993, o Governo federal reduziu a tarifa de importação de trigo e farinha de $15 \%$ para $5 \%$, bem como as tarifas de uma série de outros produtos derivados de trigo. Além disso revogou, em 22 de março de 1993, a portaria 711 de 15 de novembro de 1992 que estabelecia a tarifa adicional de 27,9\% sobre a importação de trigo americano favorecido pela EEP. Estas medidas deprimiram os preços pagos aos produtores nacionais que reduziram ainda mais a área plantada e a produção.

Em 1994, a entrada no país do trigo canadense e alemão altamente subsidiados, e do trigo argentino favorecido por tarifa especial, pressionaram novamente os preços internos, desestimulando mais uma vez os produtores, apesar do plano de incentivo à produção instituído pelo governo em março deste ano.

Em 1995, o Brasil produziu apenas $19 \%$ de suas necessidades de consumo interno que foram neste ano de 8.150 mil toneladas. Esta diferença está sendo suprida pelo trigo importado, preferido pela indústria moageira nacional. Os leilões realizados pela Companhia Nacional de Abastecimento (CONAB) para escoamento dos estoques oficiais oriundos das escassas operações de EGF e AGF freqüentemente encontram dificuldades para a venda, consequiência da maior procura por parte dos grandes moinhos pelo cereal importado.

São muitas as insatisfações do setor produtivo do trigo no Brasil, que são refletidas na baixa produção nacional após a desregulação do mercado. Mendes et al. (1994) citam alguns problemas levantados pelos técnicos e produtores na câmara setorial do trigo, órgão 
criado em 1990 com a finalidade de apoiar tecnicamente o Conselho Nacional de Agricultura na formulação e implementação de políticas de desenvolvimento da triticultura nacional: ausência de política satisfatória de preços mínimos; preços mínimos insuficientes para cobrir os custos operacionais; carência de recursos para EGF e AGF para pequenos produtores e EGF para médios e grandes produtores; liberação insuficiente de recursos para crédito de custeio; necessidade de agilização do PROAGRO (Programa de Garantia da Atividade Agropecuária) e atuação inconsistente da CONAB.

Apesar de todas estas dificuldades e indefinições de políticas públicas para o setor deve-se destacar o fato que a triticultura é importante para a agricultura do Sul do país, no sentido de ser uma das únicas opções de cultura que deixa o solo coberto no inverno evitando a erosão ${ }^{5}$. Além disso, ao fazer o rodízio do uso do solo com as culturas de verão, principalmente a soja, as lavouras de trigo podem reduzir em até $20 \%$ o custo destas lavouras ${ }^{6}$.

A explosiva alta dos preços no mercado internacional no primeiro semestre de 1996 despertou o interesse dos produtores brasileiros para o plantio do trigo, que se refletiu no aumento da área plantada neste ano que, segundo a CONAB, chegou a 1,61 milhões de hectares (crescimento de 56,7\% em relação a 1995). Este aumento só não foi maior devido à limitada disponibilidade de sementes e às dificuldades de crédito. Porém, na época da colheita da safra brasileira, os preços no mercado internacional voltaram a cair devido ao grande aumento da produção nos países exportadores do cereal.

Com a suspensão por parte do Governo das operações de EGF e AGF, a maioria dos produtores foram forçados a vender seu produto imediatamente após a colheita, a fim de saldar dívidas assumidas com o plantio e o trato das lavouras, ficando

\footnotetext{
${ }^{5}$ Segundo Suzuki Júnior (1995), o redirecionamento da atividade tritícola para culturas alternativas como, a cevada, a aveia e o centeio enfrenta obstáculos, explicados pela baixa demanda por estes produtos no país. Algumas das alternativas dos agricultores em substituição ao trigo, além dos produtos citados por Suzuki Júnior, têm sido o milho safrinha, o azevem, o girassol e a Canola (uma oleaginosa).
}

${ }^{6}$ Segundo estudos da EMBRAPA (Empresa Brasileira de Pesquisa Agropecuária), Lorenzon (1993). 
submetidos a preços de mercado muito baixos. Para agravar ainda mais a situação, a safra paranaense ficou extremamente prejudicada em termos de qualidade devido aos excessos de chuva ocorridos no mês de outubro de 1996, sendo rejeitado pela indústria de moagem (boa parte da safra de trigo do Paraná foi destinada à indústria de ração animal).

Para atenuar os problemas dos produtores, em outubro de 1996 o governo introduz uma nova sistemática para a comercialização do trigo. Tratava-se do prêmio para o escoamento da produção do produto (PEP), que funciona como uma espécie de subsídio para o Governo garantir à indústria a compra do trigo nacional. O governo, nesta sistemática garante ao produtor o preço mínimo de $\mathrm{R} \$ 157$ por tonelada, mas não fica efetivamente com o produto. Funcionando apenas como um intermediário, ele compra do produtor e vende simultaneamente para os moinhos e empresas beneficiadoras, promovendo leilões de equalização de preço onde o moinho que pedir o menor preço leva o produto (o prêmio de equalização é a diferença entre o preço mínimo e o preço de mercado).

2.2.3.1 Principais estados produtores.

Historicamente, a triticultura no Brasil concentrou-se no extremo sul do país. No entanto, a partir de 1980, sofreu um processo de deslocamento da área cultivada para outras regiões brasileiras, conforme mostra a Tabela 2.9 , que apresenta a evolução da área e da produção nos principais estados produtores de trigo do Brasil.

O cultivo do trigo no Brasil evoluiu significadamente após 1967, principalmente no Rio Grande do Sul, que era o principal estado produtor à época. Do Rio Grande do Sul a triticultura estendeu-se para o Paraná, onde encontrou condições privilegiadas, graças aos solos férteis e mecanizáveis. Desta forma, no final dos anos 70, o Paraná consolida-se como o primeiro produtor nacional, posição que ocupa até hoje. 
Mendes et al. (1994), apontam alguns problemas na comercialização interna do trigo nacional entre os estados exportadores do cereal (Paraná e Rio Grande do Sul) e os estados consumidores. Segundo os autores nas movimentações internas do trigo nacional, o estado produtor se apropria de $12 \%$ do Imposto sobre Circulação de Mercadorias (ICMS), enquanto o estado consumidor fica com 5\%. Quando se trata, porém, de movimentação de trigo importado, o estado consumidor beneficia-se da cobrança integral do tributo o que os estimularia a fazer concessões ao setor privado, no sentido de incentivar a aquisição do cereal importado.

TABELA 2.9 Principais estados produtores: Evolução da área e da produção - 1967 a 1977 e 1987 a 1995

\begin{tabular}{|c|c|c|c|c|c|c|}
\hline \multirow[t]{2}{*}{$\overline{\mathrm{ANO}}$} & \multicolumn{2}{|c|}{ PARANA } & \multicolumn{2}{|c|}{ RIO GRANDE DO SUL } & \multicolumn{2}{|c|}{ SANTA CATARINA } \\
\hline & $\begin{array}{l}\text { AREA } \\
\text { (ha) }\end{array}$ & $\begin{array}{l}\text { PRODUÇÃO } \\
\text { (t) }\end{array}$ & $\begin{array}{c}\text { ÁREA } \\
\text { (ha) }\end{array}$ & $\begin{array}{c}\text { PRODUÇÃO } \\
\text { (t) }\end{array}$ & $\begin{array}{l}\text { ÁREA } \\
\text { (ha) }\end{array}$ & $\begin{array}{c}\text { PRODUÇAO } \\
(\mathrm{t})\end{array}$ \\
\hline 1967 & 38.937 & 32.729 & 487.688 & 309.982 & 35.362 & 20.043 \\
\hline 1977 & 1.398 .226 & 1.257 .000 & 1.523 .500 & 689.700 & 11.620 & 4.553 \\
\hline 1987 & 1.717 .500 & 3.252 .126 & 981.331 & 1.628 .547 & 125.568 & 140.259 \\
\hline 1988 & 1.773 .797 & 3.250 .000 & 1.051 .188 & 1.605 .043 & 99.880 & 89.344 \\
\hline 1989 & 1.828 .680 & 3.207 .000 & 808.649 & 1.461 .720 & 97.095 & 126.340 \\
\hline 1990 & 1.197 .149 & 1.394 .052 & 988.158 & 1.168 .628 & 105.521 & 108.288 \\
\hline 1991 & 1.082 .358 & 1.825 .929 & 617.413 & 682.684 & 80.164 & 103.521 \\
\hline 1992 & 1.183 .143 & 1.556 .005 & 489.317 & 905.332 & 72.025 & 106.321 \\
\hline 1993 & 663.900 & 951.924 & 596.312 & 917.325 & 79.131 & 100.651 \\
\hline 1994 & 630.314 & 1.076 .306 & 554.129 & 806.983 & 61.004 & 74.147 \\
\hline $1995^{*}$ & 628.000 & 1.055 .000 & 270.197 & 336.116 & 35.680 & 48.105 \\
\hline
\end{tabular}

Fonte: IBGE; SEAB/DERAL (Dez/1995) * Dados preliminares 
Outros dois aspectos apontados pelos autores, que dificultam a comercialização do produto nacional, vis a vis ao importado, são os custos de transporte marítimo do produto nacional, que seriam superiores aos custos do transporte internacional, e as taxas de juros e os prazos para financiamento externos incidentes na aquisição do trigo, que seriam mais favoráveis que os internos.

\subsubsection{A pesquisa agronômica no Brasil.}

A preocupação da pesquisa agronômica no Brasil, à época do mercado regulado, se direcionou para o desenvolvimento de cultivares de trigo que obtivessem maior rendimento fisico, apresentassem boa resistência a doenças e que fossem adaptáveis às condições edafoclimáticas das diversas regiões produtoras do país.

Apesar do sucesso da pesquisa no que se refere à obtenção de cultivares de melhor qualidade, estes apresentam uma quantidade de glúten (proteína) menor que a do trigo importado e, em conseqüência, são menos adequados à obtenção de uma melhor massa.

A qualidade de um trigo depende basicamente da quantidade e da qualidade das proteínas presentes no grão. Segundo Silva (1989), há quatro tipos básicos de trigo: durum, cuja grande quantidade de glúten retém o amido do trigo e é ideal para a produção de macarrão; duro, que possui alto grau de absorção de água e é ideal para a produção de pães; branco, que apresenta pouco glúten e é adequado para a fabricação de bolos; e mole, cuja farinha teoricamente serve para a produção de qualquer subproduto, sem no entanto, garantir a qualidade.

Para Mandarino (1993), a qualidade de um determinado tipo de trigo não pode ser avaliada a partir de um único parâmetro ou propriedade. $\mathrm{O}$ autor afirma que a qualidade do cereal depende, além das características fisico-químicas do grão, do sistema de moagem 
utilizado para a produção da farinha, das características fisicas da massa e do processamento empregado para a obtenção do produto final.

Tendo em vista a liberação do mercado de trigo, uma das estratégias da indústria de moagem a fim de conquistar novos consumidores e ampliar os seus mercados, é a diferenciação de seus produtos. Para a indústria oferecer produtos diferenciados de melhor qualidade, certamente necessita de matéria-prima superior. Assim, o conceito de peso hectolitro, muito utilizado no Brasil à época do mercado regulado, como critério básico para a compra do cereal passa a ter valor secundário para a indústria, que passa a considerar os conceitos de qualidade industrial ou de panificação, conceitos estes muito utilizados em países com comercialização privada e, principalmente exportadores de trigo.

Com a liberalização da comercialização os produtores passam a ter portanto, uma preocupação adicional no que se refere a qualidade do trigo produzido, pois os moinhos, principais compradores do cereal, além de avaliá-lo pelo $\mathrm{PH}$ (peso hectolitro), passaram a fazê-lo também pelo teor de glúten (proteína). Alguns produtores brasileiros já vêm produzindo trigo de boa qualidade, principalmente os da variedade semidura, que é absorvido pela indústria a um bom preço.

Os centros de pesquisa agrícola no Brasil têm se dedicado à pesquisa e ao desenvolvimento de variedades de trigo de melhor qualidade adaptáveis às condições brasileiras, principalmente as semiduras preferidas dos moinhos. O Instituto Agronômico de Campinas (IAC), por exemplo, prepara a primeira variedade brasileira de trigo duro destinada exclusivamente à produção de macarrão do tipo italiano. 
2.2.4 Evolução dos preços de trigo em grão importado e dos preços pagos aos produtores brasileiros

Pelos dados da Tabela 2.10, verifica-se a evolução dos preços nominais do trigo importado e do preço pago aos produtores nacionais para o período de 1967 a 1995 . Com relação aos preços de importação, verifica-se que eles se mantiveram em baixa no período de 1967 a 1972, face às medidas protecionistas e à sistemática formação de estoques dos países produtores, apesar das tentativas de elevá-lo em 1967.

Em 1973, há uma elevação desses preços, devida às volumosas aquisições de trigo por parte da antiga União Soviética-URSS (principalmente de trigo americano) que teve uma quebra de sua safra em 1972. Em 1974 os preços se mantêm em um patamar ainda mais elevado que no ano anterior.

Com os preços de importação do cereal ficando acima dos preços pagos ao produtor em 1993, o governo brasileiro opta por não repassar esta diferença ao consumidor final, iniciando desta forma o subsídio ao consumo de trigo, subvenção que só foi eliminada em 1987.

De 1975 a 1977 se observa um declínio dos preços nominais do cereal importado. Porém, se estabilizam bem acima do nivel anterior, devido ao novo patamar de custos e preços decorrentes do choque do petróleo e da inflação mundial do período. De 1978 a 1980, os preços entram numa nova trajetória ascendente devido à política americana de elevação do preço suporte para a agricultura, ao segundo choque do petróleo e às crescentes compras soviéticas do cereal. 
TABELA 2.10 Preços nominais pagos aos triticultores nacionais e preços de importação de trigo, Brasil, 1967 - 1995.

\begin{tabular}{|c|c|c|}
\hline$\overline{\mathrm{ANO}}$ & $\begin{array}{l}\text { PREÇO PAGO AO PRODUTOR } \\
\text { BRASILEIRO. (US\$/tonelada) }\end{array}$ & $\begin{array}{c}\text { PREÇO DE IMPORTAÇÃO } \\
\text { (US\$/tonelada) }\end{array}$ \\
\hline 1967 & 116.75 & 62.53 \\
\hline 1968 & 103,15 & 57.96 \\
\hline 1969 & 106,39 & 59,96 \\
\hline 1970 & 102,62 & 60.78 \\
\hline 1971 & 98,50 & 62.68 \\
\hline 1972 & 98,56 & 78.70 \\
\hline 1973 & 121,75 & 137.42 \\
\hline 1974 & 194,42 & 192.72 \\
\hline 1975 & 188,06 & 155,35 \\
\hline 1976 & 181,64 & 132.70 \\
\hline 1977 & 206,14 & 107.01 \\
\hline 1978 & 212,19 & 125.32 \\
\hline 1979 & 172,30 & 162.67 \\
\hline 1980 & 197,34 & 184.64 \\
\hline 1981 & 248,98 & 177,49 \\
\hline 1982 & 272,75 & 169,12 \\
\hline 1983 & 207,65 & 159,57 \\
\hline 1984 & 228,49 & 149,61 \\
\hline 1985 & 251,01 & 141,11 \\
\hline 1986 & 237,89 & 97,09 \\
\hline 1987 & 185,34 & 93,98 \\
\hline 1988 & 183,78 & 104,14 \\
\hline 1989 & 177,01 & 163,37 \\
\hline 1990 & 137,67 & 151,87 \\
\hline 1991 & 111,83 & 99,40 \\
\hline 1992 & 136,67 & 122,05 \\
\hline 1993 & 128,67 & 127,56 \\
\hline 1994 & 125,83 & 122,65 \\
\hline $1995^{*}$ & 162,00 & 122,13 \\
\hline
\end{tabular}

Fontes: Preços ao produtor nacional e de importação para o período de 1967 a 1989: Mendes et al. (1994), com base nos dados da CFP, CTRIN, SUNAB, CACEX.

Preços ao produtor nacional de 1990 a 1995: Hubner (1996) com base nos dados da SEAB/DERAL.

Preços: de importação de 1990 a 1995: SECEX/DECEX (1996)

* Dados preliminares 
A partir de 1981, os preços nominais de importação do trigo passam a cair. Os subsídios às exportações, os estoques elevados e a redução do volume de importações, decorrente da recessão mundial do início dos anos oitenta e da redução da procura por parte de tradicionais importadores (China, URSS e Brasil), que obtiveram safras elevadas, fizeram com que a oferta do produto crescesse além da demanda. Estes preços mantiveram-se a níveis relativamente baixos até 1987, elevaram-se em 1989 e 1990 e reduziram-se novamente em 1991. De 1992 a 1995, mantiveram-se a níveis médios de US\$ 122 a tonelada.

A redução da produção mundial nos últimos anos, o aumento da demanda da China e principalmente a redução da relação estoque/consumo mundiais, somados a outros fatores conjunturais, contribuíram para a alta dos preços internacionais do trigo no primeiro semestre de 1996. Em maio deste ano, o produto chegou a ser cotado ao nível histórico de US\$ 340 a tonelada (em maio de 1995 era cotado por US\$ 150 a tonelada). Entre junho de 1995 e junho de 1996 o trigo do Canadá, segundo maior exportador, passou de US\$165 para US\$ 250 a tonelada (acréscimo de 51,5\%); no mesmo período, o trigo americano passou de US\$ 159 para US\$ 235 a tonelada (acréscimo de 47,8\%). No segundo semestre de 1996, no entanto, os principais paises exportadores colhem uma supersafra de trigo, ocasionando uma queda nas cotações do cereal no mercado externo.

Como o Brasil tornou-se um importador expressivo do cereal, a partir de 1990 o preço aos produtores nacionais, e conseqüentemente o estímulo dos mesmos à produção, passou a ser balizado pelos preços do produto no mercado externo que, como já salientado, são mantidos artificialmente baixos pelos principais exportadores.

\subsection{OS IMPACTOS DA REGULAÇÃO SOBRE A INDÚSTRIA DE MOAGEM.}

Dentre os vários objetivos do Decreto-Lei 210 de 1967, que regulou completamente todo o setor trigo por mais de 20 anos, podem ser citados como os mais importantes: 1) dar 
prioridade ao trigo nacional; 2) regulamentar a comercialização do trigo; 3) garantir o abastecimento regular do mercado a preços finais administrados (a SUNAB foi o órgão encarregado de estimar anualmente as necessidades de consumo das oito zonas em que fora dividido o país e de definir as cotas a serem distribuídas aos moinhos nestas zonas, de acordo com a demanda); 4) ampliar a capacidade de ensilagem dos moinhos (a meta era que em nove anos cada moinho tivesse uma capacidade de ensilagem que garantisse o seu fiuncionamento ininterrupto durante 20 dias, caso contrário a unidade teria o seu registro de operação na SUNAB cancelado; ao moinho que por ocasião da distribuição das cotas de trigo comprovasse certa capacidade de ensilagem seria distribuída, também, uma cota adicional do cereal como estímulo a esta expansão); 5) controlar a capacidade de moagem dos moinhos impedindo a sua expansão além dos limites da demanda, a fim de diminuir a grande capacidade ociosa existente em 1967; 6) regulamentar os desdobramentos, incorporações e transferências de moinhos, permitindo-as apenas quando necessárias a equalização da capacidade de moagem das regiões as necessidades da demanda.

2.3.1 A subvenção à produção e ao consumo através do sistema de preços

O total controle da comercialização do trigo, principalmente através da administração dos preços e da definição do Governo como único comprador do trigo nacional e importado e único vendedor do produto aos moinhos, foi uma das alterações mais importantes introduzidas pelo Decreto-Lei 210 de 1967 e possibilitou o estabelecimento de subvenções à produção e ao consumo de trigo.

O governo protegia e incentivava a produção nacional impedindo que os preços de comercialização do cereal no mercado externo refletissem no mercado doméstico, adquirindo o produto brasileiro geralmente a preços superiores ao importado (o trigo importado era adquirido para suprir déficit de produção interna e sem tarifas, pois era o próprio governo o comprador do produto). Da mesma forma, estabelecia o preço de venda dos derivados 
(farinhas, farelo e pães, fundamentalmente) e os de venda aos moinhos (entre 1967 e 1972, os preços de venda à indústria de moagem foram a média ponderada do trigo nacional $\mathrm{e}$ importado). A manutenção de um diferencial de preços favorável ao trigo brasileiro e sua proteção frente à concorrência externa representaram a concessão de um subsídio direto à produção por parte do Estado.

Em 1973, o governo brasileiro decide não repassar aos consumidores o aumento dos preços do trigo ocorrido no mercado internacional naquele ano, passando a vendê-lo aos moinhos a um preço inferior ao da aquisição no exterior, instituindo assim explicitamente o subsídio de preços ao consumo. Tendo em vista o trigo ser um produto de primeira necessidade que teve seu consumo ampliado com o processo de urbanização passando a ter, portanto, um peso considerável na formação dos índices de preço, o governo decide manter este subsídio por mais tempo. Assim, através desta política, o trigo e seus derivados ficaram muito mais baratos que outros alimentos básicos para a população, incentivando ainda mais o consumo e diminuindo o seu peso nos orçamentos familiares. Este subsídio, que era para ser apenas conjuntural, vigorou por 14 anos no Brasil, sendo eliminado somente em 1987, com o plano Besser.

Mendes et al. (1994), calcularam os dispêndios totais do governo com a subvenção de todo o sistema de produção e comercialização do trigo para o período de 1967 a 1989. Segundo os autores, de 1972 a 1987 (período do subsídio ao consumo) o total das subvenções alcançaram seus maiores volumes e, a partir de 1981 há uma redução substancial dos recursos dispendidos pelo governo com a política. Isto já decorria da crise financeira do Estado e da pressão do Fundo Monetário Internacional (FMI), para a eliminação do subsídio ao consumo. Apesar das reduções ocorridas a partir deste ano, os subsídios não são eliminados. Pelo contrário, em 1983, são dispendidos os maiores volumes de recursos para manter o sistema (US\$1.465.477,80). Enfim, em 1987, com a retirada do subsídio explícito ao consumo e a permanência do subsídio implícito à produção, os volumes gastos diminuem, ficando porém ainda em níveis superiores ao período anterior à implementação do subsídio ao 
consumo. Em todo o período analisado pelos autores o governo garantiu um preço médio de venda aos moinhos inferior aos seus custos de compra ${ }^{7}$

Soares (1980), considerando que o custo de produção nacional é superior ao importado, estimou o dispêndio de recursos domésticos na produção de trigo, ou seja, o custo do país ao economizar o valor de 1 dólar nas importações de trigo. Segundo o autor, em média, do ano de 1967 a 1977, o valor de 1 dólar nas importações de trigo custou ao país 1,35 dólares.

Análises realizadas por Soares (1980) e Silva (1989), supõem que os beneficios do sistema de subsídios imposto pelo governo foram distribuídos de forma desigual entre os agentes do Complexo trigo, existindo divergências sobre quais os verdadeiros grupos sociais beneficiados com estas políticas e principalmente, se o subsídio ao consumo realmente alcançou a população ou foi absorvido pela indústria.

Quanto aos efeitos distributivos da subvenção ao consumo, Soares (1980) conclui que os consumidores de maior renda foram relativamente mais favorecidos com a política. No entanto, admite que a subvenção não deve ser analisada em termos absolutos e sim em proporção da renda dos consumidores pois, embora o beneficio recebido pela população de baixa renda seja menor em termos absolutos este, em porcentagem da renda do extrato populacional, representa mais que o beneficio recebido pela população de maior renda e por isto a política seria socialmente importante.

Silva (1989), em seu estudo, concluiu que a subvenção beneficiou mais as classes de menor renda, tanto em termos absolutos (quantidade consumida) quanto em termos relativos (participação nas despesas). Em termos regionais, a autora afirma que, apesar da região

\footnotetext{
${ }^{7} \mathrm{O}$ custo total do governo com a aquisição do cereal nacional consistia no preço pago ao produtor brasileiro, mais as despesas de movimentação até o moinho, enquanto o custo total com a aquisição do cereal importado consistia no preço pago aos vendedores estrangeiros mais as despesas de movimentação do porto aos moinhos. $O$ custo total com a aquisição do cereal consistia na média ponderada destes custos pelas quantidades compradas do trigo nacional e importado.
} 
composta pelos estados de São Paulo e Paraná ${ }^{8}$ ter sido o maior mercado regional dos derivados de trigo, foram as regiões norte, nordeste e centro-oeste as que apresentaram maior crescimento da oferta dos mesmos e conseqüentemente, o maior crescimento do seu consumo.

No que se refere ainda aos impactos sobre o consumo final Silva (1989), ao considerar que o subsídio ao consumo de trigo foi repassado aos consumidores, afirma que a política de regulação exerceu, entre outros, a função de promover o fortalecimento dos hábitos dos consumidores em favor da farinha de trigo. Esta mudança de hábitos alimentares porém, não pode ser atribuída exclusivamente à subvenção do governo pois, como chama a atenção a autora, é uma tendência natural o ritmo urbano industrial exigir alimentos de rápido preparo e de elevado grau nutricional, principalmente nos países subdesenvolvidos que mantém um ritmo de crescimento acelerado de sua população urbana. Neste sentido, a subvenção só veio a reforçar esta tendência. Soares (1980), também afirma que a urbanização e a redução dos preços da farinha, são as duas variáveis mais significativas que explicam o aumento do consumo à época da subvenção.

Silva (1989), avaliou a eficácia dos moinhos no repasse do subsídio ao consumo através do comportamento da margem de comercialização deste setor. A evolução destas margens, calculadas para o período de 1967/1987, acompanharam a evolução do subsídio ao consumo, sugerindo que os moinhos tivessem absorvido parte desta subvenção. Alerta a autora, no entanto, que apesar de importante, a análise das margens de comercialização são apenas indicativas e não devem ser observadas isoladamente, pois incorpora outros fatores relevantes para a análise. Assim, ela conclui que o aumento das margens, que já eram ascendentes no período pré-subsídio, não implicou necessariamente em absorção do subsídio ao consumo pelos moinhos porque os aumentos dos custos de trabalho ocorridos na indústria

\footnotetext{
${ }^{8} \mathrm{~A}$ autora fez sua análise por zonas de consumo, nas quais a SUNAB distribuiu o Brasil, sendo que os estados do Paraná e São Paulo faziam parte da mesma zona de consumo (zona 7). É muito provavel, no entanto, que o estado de São Paulo tenha sido, por razões óbvias, o maior mercado consumidor dos derivados do cereal.
} 
como um todo não foram efetivamente repassados aos consumidores. Porém, concorda que, possivelmente, possa ter ocorrido uma absorção deste subsídio por parte dos moinhos que operam em condições vantajosas de custos, devido à manutenção de um preço único para a farinha. Entretanto, esta absorção não parece ter sido suficientemente relevante.

Soares (1980), aponta o aumento da produção de farinhas especiais (que tinham o preço superior) em detrimento da farinha comum, como forma dos moinhos absorverem o subsídio ao consumo, tendo em vista não haver diferenças significativas de custos para produzir os dois produtos. $\mathrm{O}$ autor estimou que $1 / 3$ dos totais dos recursos utilizados pelo governo na subvenção da matéria-prima foram absorvidos pelos moinhos nesta alteração da estrutura de produção. Além deste fato, Silva (1989), aponta o aumento real do preço da farinha comum, no período 1967/87 e a liberação do preço do farelo, a partir dos anos 80, como fonte de crescimento das margens da indústria.

Na realidade, há uma grande controvérsia sobre quais os agentes foram realmente beneficiados com a política do subsídio ao consumo e principalmente, com relação à comprovação da absorção deste beneficio destinado ao consumidor por parte da indústria. Como salienta Silva (1989, p. 151):

"Há de se observar que a questão da absorção indevida do subsidio ao consumo é um terreno pantanoso, principalmente no que se refere a disponibilidade de dados, pois mesmo se verificando um crescimento no lucro da indústria, não se pode correlacioná-lo diretamente ao subsidio". 
2.3.2 O funcionamento dos moinhos no mercado regulado e os impactos desta regulação sobre o setor

Segundo Silva (1989), a regulação foi uma variável muito mais crucial no que se refere ao segmento moageiro, uma vez que há uma grande especificidade técnica de produção. Além disso, os preços do grão, bem como as cotas, eram determinados pelas agências reguladoras.

Não havia diferenciação de produto, à época do mercado regulado, mas ocorria a produção de um "mix" de produtos (farinha especial, farinha comum e farelo), possível de ser produzido por qualquer firma da indústria.

A regulação estabelecia os tipos de farinha que os moinhos podiam fabricar: farinha comum e especial, nas proporções de $60 \%$ e $40 \%$ respectivamente ${ }^{9}$. Mesmo o governo controlando os preços, os moinhos produziam e ofereciam uma farinha média (entre a especial e a comum), que vendiam pelo preço da especial e desta forma aumentavam suas margens.

Para Silva (1989), a moagem de trigo apresentava características de um oligopólio concentrado com as firmas operando sob diferentes condições de custos, devido às diferentes combinações de uso de fatores, bem como por diferenças qualitativas no equipamento utilizado. Como o governo controlava e calculava o preço das farinhas tomando por base o custo médio dos moinhos no país, os maiores e mais produtivos moinhos obtinham margens de lucros mais elevadas. Além disso, o governo financiava o capital de giro dos moinhos ao conceder prazos de até 60 dias para o pagamento da matéria-prima junto ao Banco do Brasil, enquanto estes vendiam seus produtos à vista.

${ }^{9} \mathrm{~A}$ diferença entre a farinha comum e a especial residia no teor de cinzas. 
Os objetivos principais do Decreto-Lei 210/67 com relação ao segmento moageiro era o de garantir o abastecimento de matéria-prima, ao mesmo tempo em que deveria conter o crescimento da capacidade de moagem total do parque moageiro nacional, eliminando a alta capacidade ociosa verificada em 1967.

O sistema de cotas aos moinhos foi eficiente no sentido de garantir o abastecimento regular do produto aos moinhos das zonas de consumo brasileiras. Quanto à expansão do parque moageiro nacional e à redução da capacidade ociosa, os objetivos também foram atingidos, haja vista a redução da capacidade ociosa, nos 20 anos de mercado regulado, de 65\% em 1967 para 24\% em 1987.

Saliente-se que estes dados sobre a capacidade ociosa dos moinhos, são baseados na capacidade real do parque moageiro nacional, considerando o resultado das provas fisicas de moagem do ano de 1988 e não na capacidade de moagem registrada na SUNAB. Pela legislação da época, a SUNAB era responsável por fazer provas físicas a fim de comprovar a capacidade de moagem total do parque moageiro nacional. Com base nestas informações, este órgão Estatal registrava uma parte desta capacidade de moagem para efeito de distribuição de cotas de trigo de acordo com o consumo regional, sendo o excesso desconsiderado. Da mesma forma, a legislação obrigava os moinhos a realizar uma nova prova fisica cada vez que houvessem mudanças técnicas de suas instalações, possibilitando à agência pública acompanhar a evolução industrial. A SUNAB registrava em 1987, para efeito de distribuição de cotas, uma capacidade de moagem de 4.935.743,96 toneladas/ano ${ }^{10}$, enquanto a capacidade real do parque moageiro nacional, considerando as provas fisicas de 1988, era de 9.229 .109 toneladas/ano.

$\mathrm{O}$ número total de moinhos também reduziu-se significativamente neste período, passando de 386 no final de 1967 para 179 em 1987, o que representou uma redução de 54\% do número de unidades moageiras atuando na indústria. Esta redução ocorreu em todas as regiões brasileiras e, foi mais significativa para os moinhos com capacidade de moagem de ate

${ }^{10}$ Considerando 280 dias de trabalho normal por ano (Mendes et al., 1994) 
100 toneladas/24h, localizados principalmente nos estados do sul do país. Esta redução do número de pequenos moinhos, segundo Mendes (1994), ocorreu sobretudo pelo não atendimento, por parte deles, das exigências legais da SUNAB no que se refere a ampliação da capacidade de ensilagem e pela própria venda dos registros de moagem a outros moinhos (que, na maioria das vezes, eram altamente lucrativas).

Estudos de Soares (1980), Silva (1989) e Mendes et al. (1994), revelam que esta redução não alterou significativamente a distribuição do número de moinhos pelo parque moageiro, segundo suas capacidades de moagem, permanecendo praticamente a mesma estrutura concentrada existente em 1967. De fato, em 1987, haviam 116 moinhos (65\% do total) com capacidade de moagem de ate 110 toneladas diárias, respondendo por $10 \%$ do total da capacidade de moagem do país; 41 moinhos (23\%) com capacidade de 110 a 500 toneladas/dia, respondendo por $59 \%$ da capacidade nacional e 22 moinhos $(12 \%)$ com capacidade de 500 a 1200 toneladas/dia sendo responsáveis por $59 \%$ de toda a capacidade de moagem brasileira. A existência de poucos grandes moinhos detendo parcela considerável da oferta comprova esta referida concentração do setor, no ano considerado.

De acordo com Silva (1989), há fortes indícios que na indústria de moagem operam economias de escala, com os custos médios operacionais diminuindo à medida que cresce o tamanho da planta, sendo que a eficiência na produção nacional seria obtida com moinhos que operam com capacidade de 200 a 400 toneladas de trigo moídos por dia. Segundo a autora, as vantagens de custos operacionais dos grandes moinhos, foram muito importantes à época do mercado regulado ao possibilitar a obtenção de lucros elevados por parte deles.

Silva (1989), afirma que em termos espaciais a distribuição dos moinhos está relacionada com a dinâmica da formação do parque moageiro nacional ou seja, a concentração dos moinhos nas regiões produtoras (basicamente pequenas unidades) e regiões portuárias (médios e grandes moinhos) . Segundo a autora, isto se deve ao fato do baixo valor agregado relativamente ao custo de transporte, implicando que os moinhos competiriam apenas em mercados geograficamente próximos. 
Silva (1989), considerando que o grau de concentração da indústria é um indicativo de sua estrutura competitiva e, por conseguinte, de seu desempenho, analisa a evolução dos índices de concentração técnica na moagem de trigo. Na Tabela 2.11 , tem-se a evolução destes índices, calculados pela autora, de 1967 a 1987, para as oito (8) zonas de consumo em que foi dividido o mercado regulado de trigo no Brasil, a saber:

Zona 1: Amazonas, Pará e Maranhão;

Zona 2: Ceará, Rio Grande do Norte, Paraíba, e Pernambuco;

Zona 3: Alagoas, Sergipe, e Bahia;

Zona 4: Espírito Santo, e Minas Gerais (exceto triângulo mineiro);

Zona 5: Rio de Janeiro;

Zona 6: Distrito Federal, Goiás, Mato Grosso, e Minas Gerais (triângulo mineiro);

Zona 7: São Paulo e Paraná;

Zona 8: Santa Catarina e Rio Grande do Sul.

Silva (1989), utiliza três índices para calcular a concentração técnica na moagem de trigo para o período considerado:

- o índice de "Hirschman-Herfindhal" (HH), que se baseia na participação de cada firma no total do mercado. Esse índice varia de 0 a 1 . Quanto menor o índice maior é a competitividade do mercado e quando $\mathrm{HH}=1$, trata-se de um monopólio;

- e as "razões de concentração" $\mathrm{Cl}$ e $\mathrm{C} 4$, que informam, respectivamente, a participação da maior e das 4 maiores firmas na indústria.

Em relação ao índice de Hirschman-Herfindhal, observa-se: que nas zonas de consumo 1, 2, 3 e 4 há uma queda no índice de 1967 para 1987, acompanhando o crescimento do número de moinhos; nas zonas de consumo 5, 6, 7 e 8 , houve um aumento da concentração técnica no período, apesar da redução do número de moinhos. 
TABELA 2.11 Evolução da concentração técnica na indústria brasileira de moagem de trigo, segundo a capacidade real, por zona de consumo, (1967 e 1987).

\begin{tabular}{ccccccccc}
\hline \multirow{2}{*}{$\begin{array}{l}\text { ZONAS DE } \\
\text { CONSUMO }\end{array}$} & \multicolumn{2}{c}{$\mathbf{N}^{\mathbf{0} D E}$} & \multicolumn{2}{c}{ HH } & \multicolumn{2}{c}{ C1 (\%) } & \multicolumn{3}{c}{ C4 (\%) } \\
\cline { 2 - 9 } & 1967 & 1987 & 1967 & 1987 & 1967 & 1987 & 1967 & 1987 \\
\hline 1 & 3 & 4 & 0.35 & 0.26 & 38.35 & 31.63 & 100.00 & 100.00 \\
2 & 6 & 7 & 0.31 & 0.21 & 40.85 & 33.62 & 94.12 & 77.02 \\
3 & 5 & 5 & 0.30 & 0.22 & 48.21 & 33.31 & 91.03 & 85.16 \\
4 & 5 & 5 & 0.25 & 0.22 & 34.94 & 27.97 & 92.36 & 88.20 \\
5 & 8 & 6 & 0.22 & 0.30 & 38.88 & 48.72 & 79.58 & 89.25 \\
6 & 6 & 4 & 0.29 & 0.38 & 44.74 & 44.70 & 82.91 & 100.00 \\
7 & 64 & 38 & 0.05 & 0.07 & 12.44 & 14.53 & 33.44 & 55.76 \\
8 & 289 & 110 & 0.02 & 0.03 & 6.20 & 9.21 & 20.42 & 24.70 \\
\hline \hline
\end{tabular}

Fonte: Silva (1989), com base na portaria SUPER n ${ }^{\circ} 1471$ de 20/12/87.

Em relação a participação da maior planta (C1), verifica-se que, em 1987, o índice é bem elevado nas zonas de consumo $1,2,3,4,5$, e 6 e bem menos elevado nas zonas 7 e 8 .

Em relação ao índice $\mathrm{C} 4$, verifica-se que nas zonas de consumo 1 e 6, o índice é de $100 \%$, pois nessas zonas há apenas quatro moinhos. A zona menos concentrada é a zona 8 , com $24,7 \%$.

A autora conclui que, de modo geral, a moagem de trigo em 1967 era muito concentrada tecnicamente e que, nas zonas de consumo do Norte e Nordeste, apesar da queda de concentração devido ao crescimento do número de moinhos, esta continuava ainda bastante elevada em 1987. Em São Paulo, Rio de Janeiro, Paraná, Santa Catarina e Rio Grande do Sul, apesar da concentração ser menos acentuada, houve aumento do índice entre 1967 e 1987, principalmente devido ao crescimento das firmas líderes em relação ao mercado. 
Outro indicador importante da concentração da oferta, em 1987, é obtido pela análise da participação dos grandes grupos econômicos no setor de moagem de trigo.

$\mathrm{Na}$ Tabela 2.12, apresenta-se os principais grupos econômicos no setor de moagem de trigo em 1987, os quais detinham, mais da metade de toda a capacidade de moagem brasileira.O grupo Bunge y Born, de capital argentino, era o líder no setor, detendo $23,31 \%$ de todo o potencial da oferta no Brasil.

TABELA 2.12 Principais grupos econômicos no setor de moagem de trigo no Brasil, 1987 .

\begin{tabular}{lccc}
\hline \multicolumn{1}{c}{$\begin{array}{c}\text { GRUPOS } \\
\text { ECONÔMICOS }\end{array}$} & $\begin{array}{c}\text { CAPACIDADE DE } \\
\text { MOAGEM } \\
\text { REGISTRADA (t/24h) }\end{array}$ & POSIÇÃO & $\begin{array}{c}\text { PARTICIPAÇÃo } \\
\mathbf{( \% )}\end{array}$ \\
\hline Bunge y Bom & 4.110 & 1 & 23.31 \\
Macedo Dias & 1.954 & 2 & 11.08 \\
Grumar & 1.025 & 3 & 5.81 \\
Pam Sistema & 906 & 4 & 5.14 \\
J. Alves Verissimo & 378 & 5 & 2.15 \\
Indigena & 364 & 6 & 2.06 \\
Pullman & 360 & 7 & 2.04 \\
Minetri e Cia & 308 & 8 & 1.75 \\
Sadia & 262 & 9 & 1.49 \\
\hline Total dos grupos & 9.667 & - & 54.83 \\
\hline Brasil & 17.630 & - & 100.00 \\
\hline \hline
\end{tabular}

FONTE: Mendes et. al. (1994), com base nos dados do Ipardes (1988).

Para Soares (1980), a crescente e expressiva participação dos grandes gnupos econômicos no setor, representavam um fato inesperado no mercado regulado, pois 
acreditava ele que os grupos econômicos atuariam, em tese, em áreas que não sofreriam interferência tão expressiva do Estado, quer controlando o nível de atividade das empresas quer fixando as margens de comercialização do produto. 


\section{REFERENCIAL TEÓRICO E METODOLÓGICO}

\subsection{A TEORIA DA ORGANIZAÇÃO INDUSTRIAL (OI)}

A teoria da Organização Industrial (OI) nasceu em Harvard nos anos 30 como reação ao elevado grau de abstração e irrealismo da teoria econômica tradicional, especialmente no tocante ao comportamento das modernas corporações. Segundo Farina (1994, p.1),

"A análise microeconômica tradicional estuda a empresa como uma unidade econômica passiva, incapaz de modificar a estrutura industrial em que ela opera, dando ênfase $\dot{a}$ organização da economia por meio das forças de mercado. A teoria da Organização Industrial (OI), por outro lado, trata a empresa como uma unidade dinâmica, enfatizando a interação das organizações industriais com instituições encontradas no mundo real. Dentro da abordagem de OI destaca-se em primeiro lugar o fato que as empresas capitalistas modernas mostram uma evolução quanto à determinação de preços, margens de lucro, crescimento e inovação tecnológica, que refletem as mudanças na estrutura industrial em que elas se inserem e, em segundo lugar, que a própria estrutura pode ser afetada pelo comportamento dessas grandes empresas".

Koch (1980, p. 1), define Organização Industrial como: "um teórico e empírico estudo de como a estrutura da organização e conduta dos vendedores e compradores afetam o desempenho e bem-estar econômicos". Segundo o autor, a abordagem de OI é relacionada primariamente com as ações das firmas como vendedoras de bens e serviços no mercado, pois 
os economistas da OI têm raramente dado atenção ao estudo das firmas como compradoras de insumos e ao estudo da organização interna destas firmas e seus comportamentos, primeiramente pelo fato de existirem poucos dados disponiveis com respeito às atividades das firmas como compradoras de insumos e, principalmente, pela falta de dados que descrevam suas atividades internas. Em segundo lugar, porque o bem-estar econômico do consumidor está mais diretamente relacionado com as atividades de vendas das firmas que com outras atividades.

O estudo de OI é altamente dependente da teoria microeconômica, pois uma grande parte de seu aparato teórico se baseia na teoria estática dos preços. Esta é a razão da teoria da OI ser vista como uma "Microeconomia ampliada". Stigler (1968), afirma que o campo da OI realmente não existe e que esta teoria nada mais é do que a própria Microeconomia levemente diferenciada.

Koch $(1980$, p. 2) salienta que é conveniente ver a OI como um conjunto de ferramentas que são utilizadas para analisar a firma em suas várias atividades.

"A ferramenta primária é a teoria estática dos preços; entretanto, o estudo da OI não pode ser executado sem uma substancial contribuição da teoria do equilibrio geral e da economia do bem-estar (ambas as quais podem ser consideradas como parte da teoria dos preços), da matemática, da estatistica e, também de campos cognatos como psicologia e sociologia".

Segundo este autor, a análise de equilibrio geral é necessária quando do estudo das complexas inter-relações entre as firmas, mercados e setores da economia; já a economia do bem-estar deve ser aplicada quando se analisa o desempenho da firma no mercado, verificando o impacto deste desempenho para o bem-estar social a fim de, se necessário, formular políticas públicas adequadas. A matemática e a estatística são usadas na formulação de hipóteses e na realização de testes significativos sobre estas hipóteses. Outros conceitos e 
métodos dos campos de estudo da sociologia, psicologia, história, etc., também são utilizados, quando necessários, no estudo da OI.

3.1.1 O modelo de Estrutura - Conduta - Desempenho.

O Paradigma Estrutura-Conduta-Desempenho, modelo tradicional de análise de OI, proposto por Edward S. Mason ${ }^{1}$ em 1930, citado em Koch (1980), tornou-se metodologia dominante nas análises de OI até o final dos anos 70 . O modelo enfatiza uma relação causal entre Estrutura, Conduta e Desempenho da firma no mercado. Este modelo de abordagem busca explicar o desempenho da firma em termos de sua conduta no mercado, que é assumida ser dependente da organização e da estrutura e estas, por sua vez, refletem as condições de oferta e demanda dos mercados.

Segundo Koch (1980 p. 3), ao basear-se em assertivas teóricas do tipo "a organização e estrutura de mercado determinam a conduta e o desempenho", a abordagem tradicional sugere relações de causa na economia da OI. No entanto, é provável que esta direção de causa no modelo seja de mão dupla ou seja, a própria estrutura de mercado pode ser afetada pelo comportamento das empresas e essa, por sua vez, pode modificar as condições básicas de mercado.

\footnotetext{
${ }^{1}$ MASON, E. S. Price and production policies of large-scale enterprise. American Economic Review p.61-74, New York, 1939.
} 


\subsubsection{A estrutura de mercado.}

Como foi visto, a abordagem tradicional dos estudos de OI assume que existe uma influência entre a estrutura de mercado, a conduta das empresas e a eficiência com que elas exercem suas atividades.

O conceito de estrutura está ligado à maneira pela qual algumas características de um mercado afetam o comportamento e a interação entre vendedores e compradores. Koch (1980), define a estrutura de mercado como sendo composta pelos elementos estratégicos do meio ambiente que influenciam e são influenciados pela conduta e desempenho da firma no mercado em que opera.

A Tabela 3.1, extraído de Koch $(1980$, p. 5), sintetiza o modelo de análise de estrutura-conduta-desempenho. Nela, $\mathrm{o}$ autor inclui as possíveis variáveis a serem consideradas no estudo de um mercado e os elementos que devem ser entendidos como condições básicas de mercado, estrutura, conduta e desempenho das firmas.

Vale lembrar a sugestão do autor de que, a relação causal da estrutura determinando conduta e esta, por sua vez, determinando desempenho, pode ser de mão dupla. Sendo assim, as linhas tracejadas na Tabela 3.1, indicam relações de causa e efeito opostas as sugeridas pelo modelo tradicional.

Koch (1980), admite que não há consenso entre os economistas da OI quanto a quais características devem ser classificadas como condições básicas de mercado ou como elementos de estrutura de mercado. De fato, Sherer (1970), por exemplo, considera elasticidade-preço da demanda como condição básica de mercado, enquanto Caves (1964), a considera como elemento da estrutura. No entanto, esta distinção, segundo o autor, não é relevante pois a definição mais geral de estrutura de mercado compreende, além dos seus reconhecidos elementos (constantes na Tabela 3.1), também as condições básicas de mercado. 
TABELA 3.1. Estrutura de análise e possíveis variáveis para avaliação de mercados

\begin{tabular}{l|l}
\hline \multicolumn{1}{c|}{ OFERTA } & \multicolumn{1}{c}{ DENDIÇÓES BÁSICAS DE MERCADO } \\
\hline Elasticidade (própria e cruzada) & Elasticidade-preco \\
Origem da matéria-prima básica & Taxa de crescimento \\
Tecnologia & Elasticidade de substituição e cruzada \\
Durabilidade do produto & Tipo de mercado \\
Valor/Peso & Métodos de compra \\
Atitudes comerciais & Caracteres cíclicos e estacionais \\
Localização & 1 \\
Organização Sindical & 1 \\
\hline \multicolumn{1}{c|}{$\uparrow$} & $\Downarrow$ \\
\hline
\end{tabular}

\section{ESTRUTURA DE MERCADO}

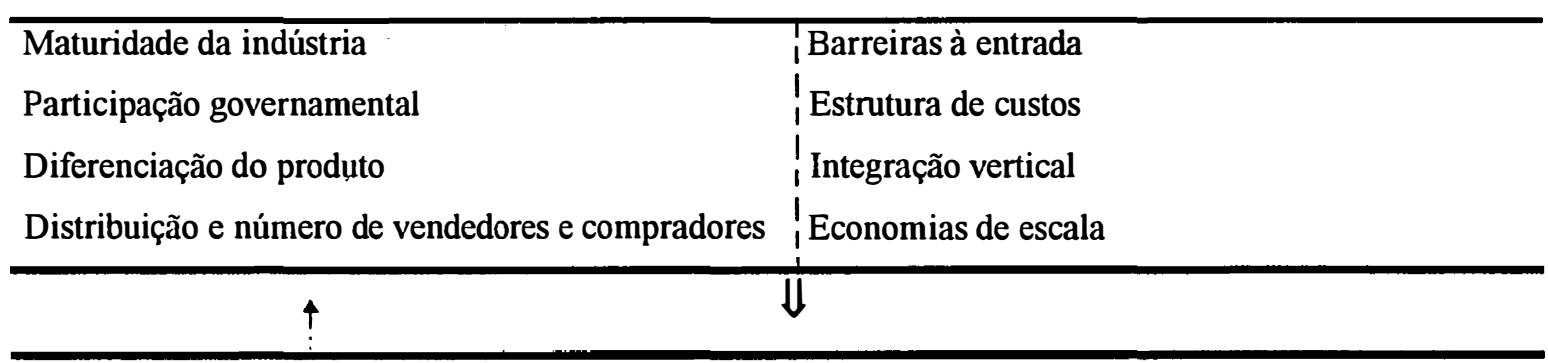

CONDUTA DAS EMPRESAS

\begin{tabular}{l|l}
\hline Colusão & Pesquisa e inovação \\
Estratégia preço & Propaganda \\
Estratégia de produtos & Táticas legais \\
Respostas as mudanças & \\
\hline & DESEMPENHO DAS EMPRESAS \\
\hline Produto & Eficiência alocativa \\
Crescimento do produto & Eficiência-X \\
Avanços tecnológicos & Eqüidade \\
Emprego & \\
\hline \hline
\end{tabular}

Fonte: Adaptado de Koch (1980, p.5) 
Bain (1958), destaca quatro elementos importantes da estrutura de mercado: a) o grau de concentração de vendedores; b) o grau de concentração de compradores; c) o grau de diferenciação de produtos e d) as barreiras à entrada de novas firmas. Poder-se-ia identificar muitos outros elementos da estrutura de mercado, mas estes parecem ser os mais importantes na prática.

Os conceitos de estrutura de mercado em concorrência perfeita, concorrência monopolística, oligopólio e monopólio descritos pela teoria microeconômica tradicional podem, sem dúvida, orientar a descrição das indústrias e mercados, mas exigem certas modificações principalmente quando se pretende identificar e medir "poder de mercado". Um oligopólio, por exemplo, de apenas 3 vendedores pode comportar-se muito diferente de um oligopólio de 15 firmas, ao menos que 3 destas 15 firmas concentrem a maior parte das vendas do mercado e as outras 12 firmas rivais subsistam com uma estreita margem.

Assim, é necessário contar-se com um instrumento de mensuração que leve em conta tanto o número como a distribuição do tamanho das firmas de um mercado: a concentração. Segundo Farina (1983), o conceito de concentração não se refere apenas ao número de participantes de um determinado mercado, mais do que isto, refere-se ao controle de uma grande proporção de uma determinada atividade econômica por uma pequena proporção dos participantes nesta atividade.

Para Marques (1991, p. 22), "concentração é a mais conhecida e utilizada medida de poder de Mercado e é normalmente definida como a distribuição do número e tamanho de compradores e vendedores num mercado".

Coelho (1979, p. 18), afirma que "o grau de concentração de uma indústria é um dos termômetros indicativos de sua estrutura competitiva e, por extensão, da relação performance real/potencial". Segundo o autor, o argumento mais comumente definido é que as indústrias altamente concentradas tendem a ter uma performance aquém da desejada (potencial) porque, nem sempre, as empresas utilizam a ampliação dos "limites de ação" ou "poder de decisão" em 
função do bem-estar da sociedade. Particularmente, elas tendem a alocar os recursos ineficientemente através da interferência direta no funcionamento dos preços, tanto de fatores quanto de produtos. Este ponto de vista, entretanto, não é aceito unanimemente: Para Schumpeter, por exemplo, economias de escala em pesquisa e inovação fazem com que o alto grau de concentração, ou quase monopólio, sejam elementos concomitantes do capitalismo moderno.

A concentração da oferta pode indicar que uns poucos produtores detêm uma parcela considerável do mercado, mesmo havendo uma "franja" competitiva na indústria. A preocupação com a concentração está relacionada com o poder de monopólio nos mercados competitivos e a possibilidade das firmas manipularem preços no longo prazo, para além daqueles vigentes em concorrência. Scherer (1970), observa, entretanto, que não existe, como a princípio possa parecer, uma relação direta entre concentração e poder de monopólio, principalmente se as estruturas industriais estiverem sujeitas à concorrência por importações ou à concorrência potencial.

Os determinantes da concentração do lado da oferta incluem economias de escala e escopo na produção e distribuição, barreiras à entrada (por exemplo, patentes, monopólio de matéria-prima, proibição legal à entrada, etc.) além das fusões e incorporações. A este respeito Labini $(1980)^{2}$, citado em Silva (1989), faz três distinções dos índices de concentração: 1) índices de concentração técnica - referente a unidades de produção; 2) índice de concentração econômica - referente a empresas eventualmente utilizando multiplantas e; 3) índice de concentração financeira - gnupos de empresas ligadas entre si por participação acionária.

Para Marques (1991, p. 22), as maiores questões com respeito à construção de índices de concentração são: 1) a definição precisa da abrangência do mercado; 2) a escolha da unidade de medida a ser usada; 3 ) a decisão quanto a incluir nos cálculos todas ou somente

\footnotetext{
${ }^{2}$ LABINI, P. S. Oligopólio e progresso técnico. Rio de Janeiro, Forense, 1980.
} 
algumas empresas no mercado e; 4) o significado e a necessidade de se incluir alguma medida de dispersão do tamanho das firmas junto com o índice escolhido.

Apesar dos índices de concentração fornecerem uma boa idéia do grau de concentração da indústria, parece ser consenso também reconhecer que todos eles apresentam limitações sendo que, a escolha do índice mais adequado a ser usado na análise é bastante arbitrária. Opta-se assim, nesta análise, pelos índices "Razão de Concentração" (C) e de "Hirschman-Herfindahl" (HH).

Para a construção do índice Razão de Concentração (C), tome-se os dados da Tabela 3.2, onde $E_{i}$ representa a íesima empresa do mercado e $S_{i}$ a participaçã́o de cada uma delas em alguma variável indicativa do tamanho deste mercado, em termos de venda, lucros, número de empregados, capacidade instalada ou outra variável.

As empresas estão ordenadas em ordem decrescente em termos de participação no mercado de forma que $\mathrm{S}_{1}<\mathrm{S}_{2}<\ldots<\mathrm{S}_{\mathrm{n}}$.

TABELA 3.2: Distribuição hipotética de " $n$ " empresas num mercado. EMPRESAS FRAÇÃO NO MERCADO

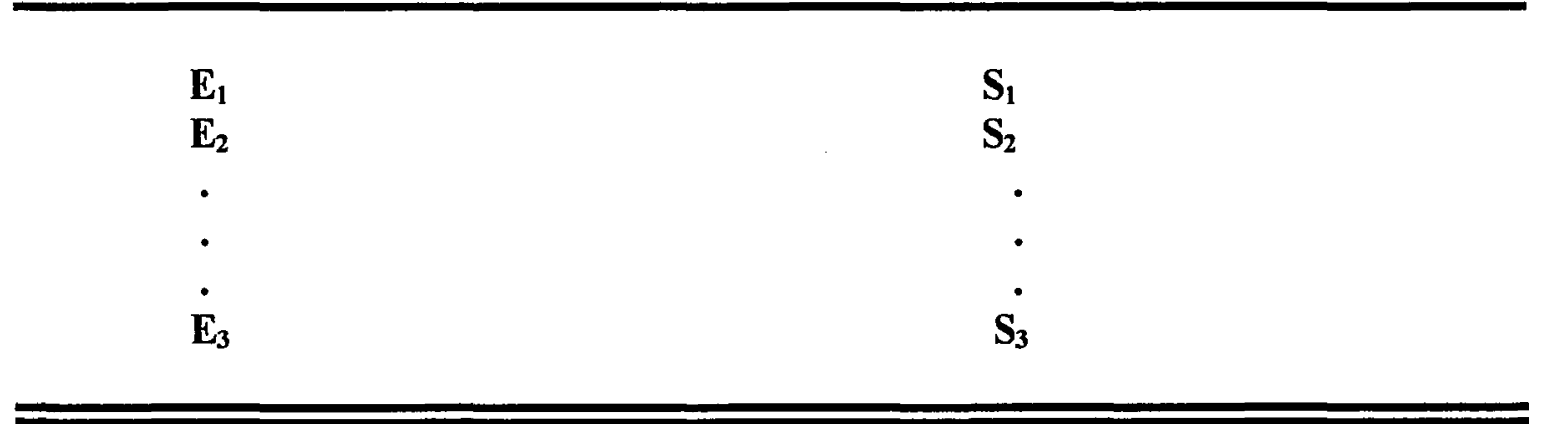

Fonte: Marques (1993, p. 25). 
A razão de concentração é, assim a proporção do mercado dominada pelas $r$ maiores empresas e é medida por:

$$
C_{r}=100 \sum_{i=n-r+1}^{n} S_{i}
$$

Marques (1993, p. 25), chama a atenção para os dois principais problemas com relação a este índice de concentração: 1) ele não dá idéia de quantas são as (n-r) empresas deixadas de fora no cômputo de $\mathrm{C}_{\mathrm{r}} \mathrm{e} ; 2$ ) ele permanece inalterado quando ocorre fusão entre as (n-r) empresas deixadas de fora no cômputo de $C_{r}$.

$\mathrm{O}$ índice de Hirschman-Herfindahl $(\mathrm{HH})$ é definido por:

$$
H H=\sum_{i=1}^{n} S_{i}^{2}
$$

onde $S_{\mathrm{i}}$ é uma fração que indica a participação de cada empresa em alguma variável indicativa do tamanho do mercado.

$\mathrm{O}$ indice $\mathrm{HH}$ está compreendido entre $(1 / \mathrm{n} \leq \mathrm{HH} \leq 1) . \mathrm{Se} H H=1$ pode-se afirmar que trata-se de um monopólio; se $\mathrm{HH}=1 / \mathrm{n}$, as empresas terão igual participação no mercado. Se $n$ tende ao infinito, então $\mathrm{HH}$ tende a zero e o mercado tende à competição perfeita.

"Uma vez que o poder de monopólio aumenta com o decréscimo do número de firmas $e$ com a desigualdade nas suas participações no mercado, pode-se dizer que o indice HH é uma boa medida de concentração porque ele é sensivel a estas duas medidas. Sua principal desvantagem é a necessidade de se trabalhar com dados individualizados por empresa para todo o mercado em estudo"(Marques, 1991, p.29). 
A diferenciação de produtos é uma das principais características da estrutura de mercado. Existe quando os consumidores revelam preferências diferentes entre as marcas individuais de um produto. Devido ao fato dos produtores venderem um produto diferenciado eles têm um relativo poder de mercado, e cada qual, portanto, pode adotar sua própria política de preços modificando assim, a forma de competição de preços. Ou seja a a importância da diferenciação de produtos-reside no fato de tornar a curva de demanda pelo produto da empresa muito menos elástica:

As barreiras à entrada de novos concorrentes no ramo compreende outro elemento importante na estrutura de mercado. Assim como a concentração reflete o número de rivais que a firma "realmente tem" no mercado, as condições de entrada neste mercado informa sobre os rivais "potenciais" da empresa.

Alguns possiveis entraves seriam: barreiras de economia de escala à entrada; barreiras de custo absoluto à entrada; barreiras de diferenciação de produto; controle sobre a oferta de insumos; requerimentos de capital e fatores tecnológicos.

Se não houver barreiras à entrada e um monopolista agir no sentido de maximizar o seu lucro no curto prazo \{Preço $>$ Custo marginal $(\mathrm{P}>\mathrm{CMg})$ \}, irá atrair rivais potenciais, comprometendo o seu poder de monopólio. A relação $\mathrm{P}>\mathrm{CMg}$ se estreitará cada vez mais, podendo no médio e longo prazo, devido à entrada de novas firmas, a indústria passar a ter um comportamento de concorrência $(\mathrm{P}=\mathrm{CMg})$. Se houverem barreiras à entrada, o monopolista pode cobrar o preço que eleva seus lucros ao máximo $(\mathrm{P}>\mathrm{CMg})$ e, mesmo assim, não atrair rivais. Pode-se medir as barreiras à entrada, portanto, pelo valor pelo qual as firmas existentes no mercado elevam seus preços acima do nível que prevaleceria em concorrência perfeita $(\mathrm{P}=\mathrm{CMg})$ sem, no entanto, atrair novas firmas ao mercado.

Uma das possíveis barreiras à entrada é estabelecer um preço tal que não proporcione lucros monopolísticos que possam atrair ou possibilitar a entrada de concorrentes potenciais no mercado. Esta prática é conhecida como "preço-limite", ou seja a firma já 
estabelecida fixa um preço de exclusão que seria inviável para a ingressante, que teria um custo maior. No limite será $\mathrm{P}=\mathrm{CMg}$ ou seja, um preço que proporcione apenas lucros normais sobre o seu capital e que seja desestimulante para a firma ingressante potencial. Para Bain (1958) a teoria do preço-limite se aplica no caso de indústrias de impedimento efetivo, onde as empresas têm que reforçar as barreiras existentes, estabelecendo preços dentro de certos limites para não estimular a entrada. O preço-limite é determinado, assim, em articulação direta com as barreiras à entrada. Para Bain (1958), a estratégia do preço-limite como barreira à entrada pode ser adotada aproveitando as economias de escala, as vantagens absolutas de custos e as barreiras de diferenciação de produto.

Uma das barreiras mais importantes à entrada de novas firmas no mercado são as economias de escala. Firmas já estabelecidas no mercado talvez estejam produzindo a níveis que permitam aproveitar todas as economias de escala possíveis, as quais não seriam auferidas por firmas novas. Esta barreira surge quando as firmas novas não alcançam os custos de produção mais baixos possíveis enquanto não tiverem crescido o bastante para ocuparem uma boa margem do mercado. Quanto maior a produção de uma única firma que tenha conseguido todas as economias de escala, tanto mais dificil será para a firma nova entrar com um tamanho eficiente e, quanto maior a desvantagem de custo da firma pequena, tanto mais dificil será partir de uma escala muito pequena e competir com êxito. Como estratégia neste caso, as firmas estabelecidas poderiam adotar um preço-limite que atenda a demanda existente e seja desestimulante para o ingressante potencial o qual, para conseguir todas as economias de escala possíveis, teria de provocar uma redução de preços via aumento de oferta, o que a levaria a um prejuízo.

Nas barreiras de custo absoluto à entrada, a firma nova enfrenta uma desvantagem de custos em relação à antiga em qualquer nível de produção. As firmas estabelecidas podem ter vantagens de custo absoluto de muitas maneiras: podem dispor de conhecimentos técnicos sobre os processos de produção que não estão disponiveis as ingressantes ou podem ter patentes que lhes concedam direitos exclusivos de determinados processos que a firma nova só obterá se pagar royalties ou gastar fundos com pesquisas para conseguir obter um método 
também eficiente, ou até mesmo podem ter exclusividade na demanda de algum insumo ou

fator de produção significativo. De qualquer forma, qualquer vantagem que a firma já estabelecida tenha de modo que a sua curva de custo médio esteja abaixo da curva de custo médio de uma firma potencialmente entrante pode se constituir numa barreira de custo absoluto à entrada. $\mathrm{O}$ preço-limite pode ser neste caso idêntico ao custo mínimo das ingressantes potenciais.

As barreiras de diferenciação de produtos permitem à firma estabelecida aproveitar-se da vantagem de já ter um produto conhecido e do fato que a firma entrante tem altos custos de desenvolvimento e promoção do seu produto, para estabelecer um preçolimite desestimulante para a firma entrante ou potencial. Uma firma que entra no mercado e decide cobrar pelo seu produto o mesmo preço das concorrentes, já estabelecidas, pode ter que gastar mais em propaganda e promoção de vendas que as firmas em funcionamento, ou seja, curvas de custos de venda médio por unidade vendida podem situar-se acima das firmas mais antigas se cobrar o mesmo preço.

Enfim, barreiras à entrada determinam efetivamente modos de ação da firma em sua busca de lucros e, o modo de ação pode determinar a estrutura. A estratégia de preço-limite, por exemplo, no sentido de criar uma barreira à entrada de firmas potenciais é vista efetivamente como uma combinação de estruturas existentes com a conduta das firmas estabelecidas, confirmando que estrutura e conduta são intrinsecamente relacionados no modelo de estrutura-conduta-desempenho.

\subsubsection{O comportamento no mercado}

Os elementos da estrutura de mercado constituem o ambiente econômico das empresas em uma indústria e a sua importância está na forma pela qual leva as firmas a se comportarem. O comportamento (ou conduta), por sua vez, estabelece uma relação entre a 
estrutura da indústria e a qualidade de seu desempenho, o que se constitui na avaliação dos resultados do comportamento de uma firma.

O comportamento do mercado consiste nas políticas de uma firma para com o mercado de seu produto e para com as atitudes tomadas por seus rivais. As políticas de fixação de preços e nível de produção, de fixação de padrões de qualidade do produto, de pesquisa e propaganda, bem como as reações da empresa às ações de suas rivais, são importantes comportamentos da firma a serem analisados.

Cada uma das estruturas de mercado estudadas na teoria microeconômica tradicional, como a concorrência perfeita, monopólio e oligopólio, proporcionam um ambiente diferente para que as empresas determinem seus padrões de comportamento no mercado. Em determinadas estruturas, as firmas não têm praticamente nenhuma liberdade de ação; em outras, essa liberdade é bem acentuada.

Os padrões de conduta nos oligopólios, por exemplo, são os mais complexos. A tomada de decisão da firma oligopolista, diferentemente de um monopólio ou de uma empresa perfeitamente competitiva, envolve importantes e complexas interações estratégicas e leva em consideração as prováveis reações de seus concorrentes.

Há várias formas possíveis de comportamento para os oligopólios, dependendo da natureża de sua interação. Da mesma forma, várias são as teorias que buscam explicar o comportamento destes oligopólios quanto à determinação de preços e quantidades ótimas. Acordos diretos entre vendedores e cartéis, liderança de preços e padrões de conluio tácito são, também, formas que os oligopólios podem usar para coordenar suas decisões de preço em um mercado.

Os padrões de comportamento dos oligopólios também se desenvolvem em torno de estratégias extra-preço. Estas estratégias em algumas indústrias parecem ser preferiveis às 
estratégias de preços, porque proporcionam uma melhor possibilidade de obter vantagem sobre o competidor antes que este possa reagir.

Como observa Marques (1991), o aspecto dinâmico da formação de preços em oligopólio está ligado à busca da manutenção ou ampliação (via diversificação e propaganda e não pela diminuição dos preços) da fatia do mercado correspondente à firma. Os preços visam viabilizar o crescimento da firma e dos lucros, mantendo uma margem, no curto prazo, sobre os custos diretos.

Barreiras à entrada, como foi visto, compreendem um segmento importante no ambiente econômico da firma. As estratégias da firma para deter a entrada de novos concorrentes no ramo, por sua vez, constituem-se em um comportamento relevante da empresa no mercado. A teoria do preço-limite reflete a importância das barreiras à entrada para a discussão de estratégias de preços no longo-prazo. Outras importantes estratégias extra-preço da firma podem efetivamente deter a entrada de concorrentes potenciais e desta forma influenciar a estrutura da indústria.

$\mathrm{Na}$ estratégia de criação e manutenção de excesso de capacidade produtiva, a barreira à entrada é constituída pela implantação de uma capacidade produtiva superior ao tecnicamente necessário para se estabelecer no mercado. Esse excesso de capacidade é uma reserva antecipada de mercado e se constitui em uma ameaça aos ingressantes potenciais. Mas esta ameaça não será eficiente no sentido de afastar os concorrentes potenciais se estes não acreditarem nela. Portanto, para que um excesso de capacidade possa se converter de fato numa barreira à entrada é preciso que a firma estabelecida tenha credibilidade de modo que diante de uma ameaça de entrada de novas firmas rivais, reaja até mesmo com uma guerra de preços com as firmas entrantes. Uma maior escala, envolvendo custos mais baixos, gera uma vantagem para as firmas estabelecidas nessa possível guerra de preços.

$\mathrm{Na}$ estratégia de preço-limite, existe uma barreira duradoura mas não absoluta à entrada, pois as firmas precisam reforçá-la constantemente estabelecendo preços dentro de 
certos limites. Em ambas as estratégias a hipótese é que as firmas podem criar barreiras no curto prazo, visando aumento de preços no longo prazo e, conseqüentemente, o lucro.

Além da estratégia do preço-limite e do excesso planejado de capacidade, existe uma série de outras estratégias extra-preço para se deter a entrada de novas firmas, como por exemplo, as de integração vertical ou contratos, o desenvolvimento de marca e a diferenciação do produto.

As firmas se integram ou fazem contratos a fim de crescerem ou de ganharem poder de monopólio. Estas estratégias são adotadas, na busca do controle de todo ou de parte do processo produtivo ou até mesmo do controle da oferta limitada de algum insumo ou fator de produção importante e especialmente significativo. Se as firmas estabelecidas conseguirem assegurar-se do abastecimento desse fator terão uma vantagem de custos em relação aos ingressantes potenciais. Se os custos de intemalização de diferentes etapas do processo produtivo for inferior ao custo de transação no mercado, a firma que se integrou ou fez um contrato tem uma vantagem absoluta de custos diante da rival potencial.

O desenvolvimento da marca do produto visa obter a lealdade do consumidor. Alguns consumidores associam o nome da indústria às características desejadas do produto. Uma firma, concorrente potencial no mercado, pode ficar desestimulada a entrar dados os altos custos de publicidade e promoção de vendas que terá de fazer se desejar cobrar por seu produto um preço igual ao da firma em funcionamento. Além dos custos unitários de publicidade mais elevados, a firma nova também poderá enfrentar um problema de escala de promoção de vendas.

A diferenciação de produtos possibilita a segmentação do mercado através da pesquisa e desenvolvimento de novos produtos e processos produtivos, da mesma forma que no caso acima a firma estabelecida terá vantagens absolutas de custos que se constituirão numa barreira à entrada para as novas firmas. 


\subsubsection{Desempenho das empresas no mercado}

Os economistas estudam o comportamento e a atuação do sistema econômico e ocupam-se de muitos aspectos das numerosas unidades comerciais de um País.

As formas de organização das firmas e como essas organizações afetam a atuação do mercado, e desse modo o bem estar econômico, é uma das preocupaçõès nos estudos de OI.

É pela ação destas firmas individuais em um mercado que muitas das metas gerais da economia são alcançadas ou não. Utilizam elas eficientemente os fatores de produção escassos? Administram corretamente os seus recursos? Produzem a melhor combinação possível de bens e serviços? Contribuem, dentro de sua capacidade, para o crescimento econômico? Planejam suas atividades de forma a ajudar a estabilizar a renda nacional e o emprego?

A teoria microeconômica neoclássica salienta que o objetivo da empresa é o da maximização de seus resultados quando da realização de sua atividade produtiva. Este objetivo pode ser obtido através da maximização da produção para um dado custo total ou pela minimização do custo total para um dado nível de produção.

Segundo Lau e Yotopoulos (1971) ${ }^{3}$, citado em Marques (1991, p. 30), a questão da eficiência econômica envolveria dois outros conceitos:

a) Eficiência-preço: esta indicaria o sucesso das firmas em maximizar os lucros, ou seja, igualar o valor do produto marginal de cada insumo ao seu preço;

${ }^{3}$ LAU, L. J.; YATOPOULUS P. A. A test for relative efficiency and application to Indian agriculture. American Economic Review, 1971. 
b) Eficiência-técnica: a empresa opera eficientemente utilizando cada combinação de insumos da forma mais eficaz possível para produzir diferentes quantidades de produto.

Em vista disto, Marques (1991, p. 31) afirma que:

"Uma firma será considerada preço-eficiente se receber de cada fator de produção exatamentè o que paga para utilizar o mesmo e, será considerada tecnicamente mais eficiente que outra firma se, dadas as mesmas quantidades de insumos quantificáveis, ela conseguir uma produção maior continuamente".

Para o autor, o uso ineficiente dos recursos (ineficiência técnica) dentro de um sistema econômico pode se dar devido a três causas: 1) firmas existentes são muito pequenas e não conseguem tirar completo proveito das economias de escala; 2) o tamanho das empresas (escala) é muito grande em relação a suas necessidades; 3 ) competição não é suficiente para obrigar as firmas a operarem no ponto de custo médio mínimo.

Lucros normais na economia, na ausência de barreiras à livre movimentação de recursos, são um importante indicador de eficiência de mercado. Outras variáveis, contudo são também relevantes, na avaliação do desempenho e eficiência de um mercado tais como: crescimento do produto, avanços tecnológicos, emprego, eficiência alocativa, etc.

3.1.2 A teoria da OI na análise do crescimento das firmas e indústrias

Guimarães (1987, p. 11), considera que parte da literatura sobre organização industrial (OI), está voltada para o teste empírico de hipóteses sobre as características e as mudanças das estruturas industriais e sobre alguns padrões de comportamento das firmas. 
Para Vegro \& Sato (1995, p. 9), "a teoria da OI tem por objetivo básico a análise do processo de crescimento das firmas, suas características e seus limites". Segundo os autores, tal abordagem consegue superar algumas limitações da teoria econômica tradicional da firma, tais como: as hipóteses do conhecimento perfeito e da maximização do lucro; a falta de realismo sobre o processo de tomada de decisão; a incapacidade de lidar com oligopólios e o equilíbrio estático, ao considerar aspectos como a interação destas empresas com o ambiente externo, suas relações internas e a estrutura de mercado. Neste sentido, autores como Marris (1971), Steindl (1976), Penrose (1979), Guimarães (1987), Porter (1990), entre outros, têm analisado o processo de crescimento das firmas contribuindo, desta forma para a construção de conceitos importantes para uma análise teórica de OI.

$\mathrm{Na}$ análise do processo de crescimento das firmas cabe, preliminarmente, no entanto, precisar dois conceitos fundamentais: o de Mercado e o de Indústria.

Para Pindyck e Rubinfeld (1994, p. 13), "mercado é um conjunto de compradores e vendedores que interagem entre si resultando na possibilidade de trocas e Indústria é um conjunto de empresas (ou firmas) que vendem o mesmo produto ou produtos correlatos".

Robinson (1953) $)^{4}$, citado em Guimarães (1987, p.33), define mercado como: "a demanda por um grupo de mercadorias que são substitutas próximas entre si". Guimarães (1987, p. 33), associa este conceito de mercado com o de indústria definindo-a como: 'um grupo de firmas engajadas na produção de mercadorias que são substitutas próximas entre si"

Koch (1980), define mercado como um conjunto de firmas cada uma das quais oferecendo produtos que têm alguma substitutibilidade para os mesmos compradores. Para o autor, mercado não é sinônimo de indústria porque firmas da mesma indústria podem não oferecer produtos substituíveis e/ou podem vender seus produtos para um conjunto muito diferente de consumidores. Além disso, algumas firmas pertencentes à determinada indústria

\footnotetext{
${ }^{4}$ ROBINSON, J. Imperfect competition revisited. Economic Papers, v.2, 1960.
} 
podem oferecer várias outros produtos além daquele produto principal que a possibilitou ser incluída na indústria em questão.

Os participantes de um mercado devem ser altamente sensíveis às modificações nos termos das transações oferecidas por outros participantes e, não devem ser sensiveis a tais movimentos em outros mercados.

O mercado tem três dimensões significativas: produto, tempo e geografia. Do ponto de vista da dimensão do produto, se os produtos são substitutos próximos pode-se dizer que estão no mesmo mercado. Uma medida de substitutibilidade entre produtos é o coeficiente de elasticidade-preço-cruzada da demanda $\left(\eta_{x y}\right)$.

$$
\eta_{x y}=\frac{\text { Variação percentual na quantidade demandada do bem } \mathbf{x}}{\text { Variação percentual no preço do bem } \mathbf{y}}
$$

Quanto maior o valor positivo de $\eta_{x y}$, mais substituíveis são as mercadorias. Entretanto, não existe nenhum valor particular que permita afirmar que os produtos façam parte do mesmo mercado.

A dimensão geográfica é um fator muito importante, na definição de mercado. Por causa dos altos custos de transporte ou por outros fatores, como por exemplo a durabilidade ou não do produto, alguns mercados podem ser classificados como regionais ou nacionais. Para Koch (1980), potencialmente, substitutibilidade próxima entre produtos será sem significado se considerações geográficas não permitirem competição real entre os fornecedores para um mesmo conjunto de clientes.

A dimensão tempo de um mercado também é importante, principalmente pelo fato de que as elasticidades-preço da demanda e oferta crescem em função do tempo. Quando 
procura-se determinar se duas empresas competem entre si, deve-se especificar um período de tempo. Este não deve ser tão curto a ponto de incluir no mercado apenas firmas existentes, nem tão longo a ponto de permitir mudanças substanciais em tecnologia, demanda e gostos, que alterariam completamente a situação.

Marris $(1971)^{5}$, citado por Guimarães (1987), afirma que o processo de crescimento é o núcleo de análise da firma e enfatiza a possibilidade da empresa modificar seu meio ambiente e portanto, superar os limites impostos a sua expansão. Para ele, um dos motivos que estimulariam este crescimento seria a separação da propriedade e controle da firma. Neste contexto, os administradores seriam motivados a maximizar o crescimento e não o lucro. Uma das limitações dos trabalhos deste autor, apontadas por Guimarães (1987, p. 11 e 12), deriva da ênfase dada a capacidade da firma de modificar o seu meio ambiente.

"Tais trabalhos focalizam-na (a firma), usualmente como uma entidade isolada e ignoram os efeitos das estruturas da indústria $e$ dos mercados sobre o seu crescimento; neste sentido, considerando um contexto não-especificado, deixam de levar em conta os diferentes padrões de crescimento associados às distintas estruturas de mercado".

Steindl (1976), reconhece o condicionamento imposto pela estrutura do mercado e da indústria ao crescimento da firma; no entanto, ignora aspectos importantes no processo de competição industrial e crescimento, como a diferenciação de produto e a diversificação das atividades da firma.

Penrose (1979), destaca a capacidade interna dos gerentes em superar os obstáculos externos ao crescimento da firma e minimiza os efeitos da estrutura e da conduta do mercado sobre este processo de crescimento. Para a autora, a diversificação é

${ }^{5}$ MARRIS, R. Introduction to theories of corporate growth. Londres: Macmillan, 1971. 
a forma de expansão mais natural que se apresenta e ocorre em função de sua área de especialização e base tecnológica.

- De fato, a diferenciação de produtos e a diversificação das atividades da firma são duas novas possibilidades para a firma em seu esforço de maximizar o seu crescimento. A tese central da análise é que a firma para desenvolver este potencial de crescimento depende da existência de oportunidades para investimentos que, por sua vez, serão determinados pela taxa de crescimento do mercado da firma.

Apesar da preocupação da maioria dos teóricos da OI com a análise do crescimento da firma reconhece-se que, principalmente quando ela tem alguns limites na absorção de recursos externos, esta sua possibilidade de crescimento fica condicionada a sua capacidade de gerar lucros que, por sua vez, dependem da taxa de crescimento da firma na indústria.

Penrose (1972), sugere que crescimento e lucro se tornam equivalentes para programas de investimentos, principalmente quando estes lucros são utilizados basicamente para reinvestimento na própria firma ao invés de reembolsar os proprietários pelo uso de seus capitais ou pelo risco incorrido.

Considerando que a acumulação interna dos lucros não tenha outro objetivo senão o de financiar o investimento e o crescimento, pode-se admitir que a existência deste capital acumulado internamente pela firma servirá de estímulo para seus investimentos. Esta acumulação interna, mais o montante de capitais de terceiros que ela pode absorver definem, portanto, o potencial de crescimento da firma em determinado periodo. Dada a sua disposição para investir, o problema da firma passa a ser o de encontrar as melhores aplicações para estes recursos que contribuam para o seu crescimento e o aumento de lucros. 
- Para Guimarães (1987), a firma pode realizar investimentos de expansão (para aumentar a capacidade de produção), de modernização (destinado a modificar o processo produtivo com vistas a reduzir os custos ou melhorar a qualidade dos produtos) e de reposição (destinado a substituir os bens de capital por desgaste). A taxa de retorno esperada sobre o investimento pode ser o critério para a decisão da firma de investir em expansão. No entanto, este critério é irrelevante quando a demanda de mercado pelo produto da firma for crescente ou quando a firma decide manter a sua participação no mercado.

- Sem dúvida, a firma poderá continuar investindo mesmo que a taxa de retorno for baixa quando decide, por exemplo, manter sua participação no mercado. No entanto, provavelmente não investirá se não houver crescimento da demanda, pois acumulará capacidade ociosa.

Neste sentido, a taxa de crescimento da demanda parece ser a variável mais relevante na decisão da firma de investir. Nada obstante, esta taxa pode não determinar o limite de expansão da firma, desde que ela empreenda esforços para modificar esta tendência. Assim, a firma pode superar os limites impostos ao seu crescimento através: da aceleração do ritmo de crescimento da demanda de seu mercado (que pode ser impulsionado através de propaganda e promoção de vendas); da absorção de parte da demanda suprida por seus rivais no mercado, aumentando desta forma a sua "fatia" neste mercạdo (isto é possível, por exemplo, através da expulsão do mercado das firmas menos eficientes ou através de fusões ou aquisições); da modificação de sua linha de produtos (através da diferenciação de produtos) e da expansão para fora do seu mercado corrente, (que pode ser obtida através da diversificação de suas atividades).

- Nas indústrias oligopolistas as reduções de preço não garantem necessariamente a realização do potencial de crescimento de uma firma. Nesta situação a firma tem que encontrar escoadouros para a sua acumulação interna seja através da introdução de novos produtos (diferenciação de produtos), seja realizando novos investimentos em outras 
indústrias e conseqüentemente expandindo-se além do seu mercado corrente (por exemplo, através da diversificação de suas atividades).

- A diferenciação do produto abre a possibilidade de uma nova forma de competição no interior da indústria, através da mais rápida expansão do mercado ou da defesa de sua posição neste. Para que uma firma empenhe-se na competição por diferenciação de produto é necessário que conheça aquilo que os consumidores potenciais consideram como melhor, em comparação aos produtos existentes. Um sabor diferente, qualidades dietéticas, maior durabilidade ou uma melhor qualidade do produto são critérios importantes que o consumidor atual leva em consideração na escolha do produto. Além disso, as oportunidades de diferenciação de produto podem ser mais ou menos limitadas dependendo do grau de percepção das mudanças na qualidade do produto por parte do consumidor, ou seja, a maior ou menor dificuldade do consumidor de avaliar a qualidade do novo produto. Neste caso, as informações fornecidas pela firma inovadora em seus esforços de venda são fundamentais, pois as preferências podem ser induzidas ou orientadas por estes esforços e pela propaganda em geral.

- Como visto, a diferenciação de produtos pode tornar-se uma barreira à entrada para novas firmas na indústria, à medida em que a firma que possua um produto diferenciado conquiste uma maior lealdade do consumidor à sua marca ou que conte com a proteção de marcas e patentes que evitem a difusão de novas tecnologias. No entanto, a eficácia destas barreiras à entrada pela diferenciação de produtos é relativa, já que as preferências e lealdades dos consumidores podem ser superadas através de esforços de venda das firmas entrantes.

- Nos oligopólios as tentativas de uma firma para aumentar suas vendas e conquistar novas fatias de mercado através de corte de preços ou intensificação dos esforços de venda são facilmente percebidas pelos rivais, que reagem quase que imediatamente. No caso de uma diferenciação de produto, nem sempre é possível se 
imitar a inovação e, principalmente, as reações das firmas rivais são mais demoradas, pois dependem de esforços na pesquisa de novos produtos.

- Outra forma da firma superar a restrição imposta ao seu crescimento pelo ritmo de expansão da demanda de seu mercado, é a diversificação de suas atividades e a realização de investimentos em outras indústrias. Esta diversificação pode também estar associada, a possibilidade da firma reduzir os riscos e as incertezas da operação em um único mercado e também no de minimizar os efeitos das flutuações cíclicas ou ocasionais de demanda. As bases tecnológicas ou áreas de comercialização condicionam, em geral, o horizonte de diversificação das firmas.

- A integração vertical pode ser uma forma da firma diversificar suas atividades evitando os riscos e incertezas geralmente associados à operação nesta nova atividade. Segundo Williamson (1985), a decisão de integrar-se verticalmente depende da comparação dos custos de transação internos e externos à firma. O principal elemento que o autor relaciona com a economia dos custos de transação é o ativo específico. Quanto mais específico é um ativo, menor é o custo de produzi-lo internamente vis a vis ao custo de obtê-lo no mercado.

$\mathrm{Na}$ maioria das análises teóricas sobre o crescimento das firmas e nos estudos de OI em particular persiste, no entanto, uma importante limitação que é a hipótese implícita de uma economia fechada, sem relacionamento com o exterior. Como observa Guimarães (1987, p. 12):

"Trata-se de uma limitação grave, não apenas porque os mercados externos e o investimento no exterior desempenham um papel importante no processo de expansão das firmas e conseqüentemente afetam os padrões de competição da indústria, mas também porque a presença de subsidiárias de firmas estrangeiras pode afetar significativamente a dinâmica de certos mercados e indústrias nacionais". 
Guimarães (1987), salienta que o impulso das economias capitalistas em penetrar em um novo mercado nacional, aparece também como resultado de potenciais de crescimento superiores àqueles compatíveis com o ritmo de expansão da demanda de seus mercados correntes. A intenção seria encontrar um escoadouro para a sua acumulação interna. Para o autor, na perspectiva de uma economia aberta, uma modificação no mercado corrente de uma firma resultará não apenas da diversificação de suas atividades, mas também desta penetração em um novo mercado nacional.

Para Porter (1990) ${ }^{6}$, citado em Vegro \& Sato (1995), a busca de mercados externos pode ter como objetivo a sustentação ou expansão de alguma vantagem competitiva que a firma conquistou no mercado interno, visando dar continuidade à sua trajetória de crescimento.

${ }^{6}$ PORTER, M. The competitive advantage of nations. Harvard Business Review, p.73-93. mar./apr. 1990. 


\subsection{METODOLOGIA}

Método são procedimentos intelectuais e técnicos adotados para se atingir o conhecimento ou a demonstração da verdade.

Os teóricos da metodologia cientifica, em especial na economia, ao invés de definir um único método capaz de servir a toda sorte de investigação, preferem falar em diversos métodos, aplicáveis conforme a natureza do objeto a ser investigado e as disposições do pesquisador (Gil, 1991, p. 21).

De fato, Gil (1991), ao propor uma classificação dos métodos de análise em economia reconhece que, na realidade eles não são adotados em sua forma pura pois, na maioria das investigações, observa-se a conjugação de um ou mais destes métodos.

Tendo em vista o objetivo central, proposto no presente estudo, de descrever as principais características do setor de moagem de trigo no Brasil, enfatizando os aspectos de estrutura, conduta e desempenho deste setor, optou-se por uma pesquisa de caráter descritivo. Segundo Boyd e Westefall (1964) ${ }^{7}$, citado em Rocha Júnior (1994, p. 64), "esta pesquisa, descreve as características dos fenômenos, procurando classificá-los, explicá-los e interpretálos".

$\mathrm{O}$ método que proporcionou a base lógica e a garantia da objetividade necessária para o tratamento dos fatos, foi o indutivo. Segundo Gil (1991, p.23), "o método indutivo parte do particular e coloca a generalização como um produto posterior ao trabalho de coleta de dados particulares". De acordo com o raciocínio indutivo, a generalização não deve ser buscada aprioristicamente, mas constatada a partir da observação de um número de situações e comportamentos concretos suficientemente confirmadores desta realidade.

${ }^{7}$ BOYD JR, H. W. WESTEFALL, R Pesquisa mercadológica. Rio de Janeiro: Fundação Getúlio Vargas, 1964. 315p. 
Nada obstante, o método dedutivo foi utilizado também, em muitos momentos da análise, pois este raciocínio auxiliou no entendimento de certos fenômenos bastante gerais, apesar dele não ser útil para descrever as características concretas e essenciais destes fenômenos. $\mathrm{O}$ método indutivo, tem um aspecto muito mais dinâmico enquanto o raciocínio dedutivo é mais estático e imutável. Para Gil (1991, p. 22), "o método dedutivo procede inversamente ao indutivo partindo do geral para o particular". Segundo o autor, "O raciocínio dedutivo parte dos princípios gerais considerados como verdadeiros e indiscutíveis para chegar a conclusões de maneira puramente formal, isto é, unicamente de sua lógica".

O estudo da indústria de moagem de trigo no Brasil fundamentou-se na teoria da Organização Industrial, sendo que o modelo de estrutura, conduta e desempenho balizou a análise do crescimento desta indústria. $\mathrm{O}$ período da análise foram os anos pós-desregulação do mercado (a partir de 1990). Porém, uma revisão do período anterior a esta desregulação foi necessária, para se entender as profundas alterações que o longo controle do Estado causou a todo o CAI tritícola.

Como visto, o quadro analítico básico da teoria da OI estabelece que o desempenho das empresas industriais é determinado pela estrutura de mercado em que elas operam, a qual, por sua vez, condiciona as práticas de concorrência. A estrutura é grandemente determinada por fatores tecnológicos e pelas condições básicas de demanda e oferta. Admite-se que o desempenho pode modificar a estrutura e a conduta, descrevendo um processo de retroalimentação do sistema. Entretanto, a absoluta maioria dos trabalhos empíricos e teóricos que seguem esta tradição da OI enfatiza a relação de causalidade da direção da estrutura para o desempenho, fazendo hipóteses sobre a conduta consistentes com aquela relação. No entanto, é importante reconhecer, quando da análise, que esta relação de causa proposta pelo modelo tradicional é de mão-dupla. 


\subsection{Procedimentos empíricos}

Como procedimento inicial básico na execução da pesquisa esteve a revisão dos principais trabalhos existentes a respeito da estrutura, comportamento e desempenho da indústria de moagem brasileira no mercado regulado. Para a investigação empírica dos índices de concentração técnica e econômica da indústria de moagem no Brasil para o ano de 1996, foram utilizados os dados de capacidade de moagem dos moinhos e dos grupos econômicos envolvidos no setor, gentilmente cedidos pela Associação Brasileira da Indústria do Trigo (ABITRIGO). A listagem completa dos moinhos existentes no país em 1996, bem como das unidade associadas aos grandes grupos econômicos, também fornecidos por esta associação, foram importantes para avaliar-se a evolução do número de moinhos existentes na indústria de moagem brasileira, bem como as mudanças na estrutura econômica do setor.

Os dados referentes à importação de trigo, farinha e outros derivados do grão por país de origem, foram utilizados para a identificação das estratégias de aquisição de matériaprima (controle da oferta de insumos) por parte das empresas moageiras, bem como o impacto desta concorrência de importações de derivados para os moinhos. Estes dados foram obtidos junto ao setor de estatística do Banco do Brasil e do Departamento de Comércio Exterior/DECEX.

Estatísticas referentes à evolução dos preços dos derivados de trigo (pão, massas, biscoitos), bem como da melhoria da qualidade destes produtos foram, também, avaliadas. $\mathrm{O}$ crescimento da oferta de derivados foi um indicador importante para a analise do desempenho do mercado.

$\mathrm{Na}$ análise do crescimento das firmas moageiras foram verificadas as fusões e incorporações de empresas e gnupos econômicos nos últimos seis anos. Foram analisadas também, neste mesmo período, a evolução e o desempenho das vendas, faturamento e lucros de alguns moinhos representativos do setor, através dos seus balanços anuais, resumidos e 
publicados na revista "Balanço Anual" (Gazeta Mercantil), com o objetivo de avaliar o potencial de crescimento destas empresas na indústria.

Foi utilizado também, um questionário de perguntas abertas e fechadas (vide anexo 1), que foi encaminhado aos 202 moinhos associados à ABITRIGO em 1996. Convém ressaltar que uma parte deste questionário foi elaborado para verificar a capacidade de moagem dos moinhos, tendo em vista haver indícios de muitas divergências entre a capacidade de moagem registrada na SUNAB à época do mercado regulado, e a real capacidade dos moinhos. Além disto foram solicitadas informações a respeito da capacidade de estocagem de trigo em grão e farinha a fim de avaliar o potencial de armazenagem das empresas. A maioria das perguntas fechadas objetivaram obter dados a respeito da conduta $\mathrm{e}$ desempenho dos moinhos frente ao ambiente de livre mercado.

$\mathrm{O}$ número de moinhos que responderam à pesquisa veio ao encontro do escopo proposto. Setenta e seis dos duzentos e dois moinhos existentes no Brasil em 1996, responderam ao questionário de forma completa onde, $20 \%$ destes são moinhos com capacidade de mais de 400 toneladas em 24h, 17\% são moinhos com capacidade de 100 a 400 $\mathrm{t} / 24 \mathrm{~h}, 46 \%$ com capacidade entre 20 e $100 \mathrm{t} / 24 \mathrm{~h}$ e $18 \%$ com capacidade de até $20 \mathrm{t} / 24 \mathrm{~h}$, o que caracteriza uma amostra bastante significativa. 


\section{A INDÚSTRIA DE MOAGEM DE TRIGO NA ECONOMIA DE MERCADO}

\subsection{AESTRUTURA DE MERCADO}

Balizando-se no referencial teórico descrito no capítulo anterior, verificar-se-á algumas variáveis importantes na avaliação da estrutura de mercado da indústria de moagem de trigo no Brasil no ambiente atual de uma economia de mercado.

Como visto, o conceito de estrutura de mercado está ligado à maneira pela qual algumas características deste mercado afetam o comportamento e a interação entre seus agentes. Uma das abordagens teóricas sugere que existe uma influência, de mão-dupla, entre a estrutura de mercado, a conduta das empresas e a eficiência com que elas exercem suas atividades. Neste sentido, o grau de concentração de uma indústria é um dos elementos importantes para a avaliação de sua estrutura e, por conseguinte, de seu desempenho.

Quando se estuda a estrutura industrial do setor moageiro brasileiro leva-se em conta alguns aspectos relevantes para a análise. Em primeiro lugar, deve-se salientar a existência de vantagens de custos na produção em escalas maiores. Grandes moinhos teriam custos médios de produção menores e, conseqüentemente, vantagens sobre as firmas menores. Em segundo lugar, a existência e operação neste mercado de grandes gnupos econômico-financeiros. E, por fim, o fato da maioria dos moinhos competirem dentro de mercados geograficamente próximos, em função do baixo valor agregado dos produtos da moagem, relativamente aos custos de transporte. Na delimitação destes mercados regionais, 
optou-se por utilizar a divisão por zonas de consumo, adotado pela SUNAB para o Brasil à época da vigência do Decreto-Lei 210/67, a fim de possibilitar algumas comparações dos mercados regulado e o atual e, também, porque esta divisão parece ser bastante realista em termos de abrangência de mercados. Nada obstante, em alguns momentos, analisar-se-á o parque moageiro considerando-se os mercados como coincidentes com a delimitação geográfica das regiões brasileiras.

4.1.1 Evolução do número absoluto de moinhos e suas capacidades instaladas de produção, por zonas de consumo

A Tabela 4.1, mostra o número de moinhos existentes no Brasil em 1987 e 1996 e suas capacidades instaladas de moagem (em toneladas/ano), por zona de consumo. Verifica-se um crescimento de $12,85 \%$ no número absoluto de moinhos no país, passando de 179 unidades em 1987 para 202 em 1996. A capacidade de moagem do parque que era de 9,23 milhões passou para mais de 14 milhões de toneladas/ano, no período.

Em todas as zonas de consumo verifica-se expansão na capacidade de moagem regional, mesmo nas zonas 1 e 8, que não apresentaram crescimento no número absoluto de moinhos e até mesmo na zona 5 , que reduziu o número de unidades moageiras. A razão disto foi a expansão da capacidade dos moinhos já estabelecidos nestes mercados.

Cabe destacar, no entanto, o crescimento elevado, de 101,24\%, de 1987 para 1996, na capacidade de oferta da zona de consumo número 8 (SC e RS). Esta elevação se deve, principalmente, à ampliação da capacidade dos chamados "minúsculos moinhos", que na busca de um melhor tamanho de planta, possível de reduzir os seus custos unitários, muitas vezes mais do que dobraram suas capacidades. 
Assim, moinhos que em 1987 eram registrados com uma capacidade de 20 ou 25 toneladas/dia, hoje chegam a ter capacidade para moerem 50 a 80 toneladas de trigo diariamente, sendo que algumas unidades aparecem até com capacidades superiores a estas. Porém, estes pequenos moinhos, muito provavelmente, são os que apresentam maiores níveis de capacidade ociosa. $\mathrm{Na}$ zona de consumo 7, o crescimento, também bastante significativo da capacidade regional deve-se, por um lado, ao crescimento do número absoluto de moinhos no Paraná (foi neste estado que houve a maior entrada de novas unidades em operação), e a expansão das já existentes (principalmente dos muito pequenos, similarmente ao que foi verificado no RS e SC) e, por outro lado ao grande aumento de capacidade de alguns moinhos de SP, que passaram a operar com um potencial de moagem de mais de 1.000 toneladas/dia.

TABELA 4.1 Capacidade de moagem instalada dos moinhos de acordo com as 08 zonas de Consumo no Brasil - 1987 e 1996

\begin{tabular}{llcccccc}
\hline \hline \multirow{2}{*}{$\begin{array}{l}\text { Zonas de } \\
\text { consumo }\end{array}$} & Região/Estado & \multicolumn{3}{c}{ Número de moinhos } & \multicolumn{3}{c}{ Capacidade de moagem (t/ano) $^{4}$} \\
\cline { 2 - 8 } & & 1987 & 1996 & cresc. \% & 1987 & 1996 & cresc. \% \\
\hline 1 & Norte & 4 & 4 & & 345.000 & 510.000 & 47,83 \\
$2 \mathrm{e} 3^{1}$ & Nordeste & 12 & 14 & 17 & 1.794 .000 & 2.370 .000 & 32,11 \\
4 & $\mathrm{MG}^{2}, \mathrm{ES}$ & 5 & 6 & 20 & 645.000 & 945.000 & 46,51 \\
5 & $\mathrm{RJ}$ & 6 & 5 & & 1.074 .000 & 1.410 .000 & 31,28 \\
6 & $\mathrm{CO}^{3}$ & 4 & 7 & 75 & 353.000 & 798.000 & 26,06 \\
7 & $\mathrm{SP}, \mathrm{PR}$ & 38 & 56 & 47,37 & 3.376 .000 & 5.580 .000 & 65,28 \\
8 & $\mathrm{SC}, \mathrm{RS}$ & 110 & 110 & & 1.641 .000 & 3.302 .388 & 101,24 \\
\hline Brasil & & 179 & 202 & 12,85 & 9.229 .000 & 14.916 .288 & - \\
\hline \hline
\end{tabular}

Fonte: Capacidade real do parque moageiro nacional, segundo o resultado das provas físicas de moagem feitas pela SUNAB em 1987. Extraído de Mendes et al. (1994). ABITRIGO (1996)

Obs. 1: A Zona de consumo 2 compreendia os estados do Ceará, Paraíba, Pernambuco e Rio Grande do Norte e a zona de consumo 3 os estados de Alagoas, Bahia e Sergipe. As zonas de consumo foram agrupadas a fim de possibilitar a comparação com os dados publicados em Mendes et al. (1994)

2: Minas Gerais exceto o Triângulo Mineiro.

3: Região Centro Oeste, exceto o estado de Minas Gerais, inclusive o Triângulo Mineiro.

4: Considerando 300 dias úteis de moagem por ano 
Observa-se também a paralisação de algumas unidades de grande porte, associadas a outros moinhos ou pertencentes a grupos econômicos. Isto pode ser justificado por uma demanda de mercado aquém do potencial de oferta, de modo que a paralisação das atividades de alguma unidade pode ser coberta pelas que continuam em operação, com nítidas vantagens financeiras na redução dos custos de operação da unidade excedente.

Confrontando-se a relação dos moinhos existentes em 1987, fornecida pela SUNAB, com a dos moinhos existentes em 1994 e 1996, fornecidas pela ABITRIGO, podese constatar, vários movimentos de entrada e saída de moinhos do setor, evidenciando que os mesmos, encontram-se ainda em processo de ajuste. No entanto, cabe observar, que são normalmente as pequenas unidades que abandonam o setor ou paralisam suas atividades (moinhos com capacidade de até $50 \mathrm{t} / 24 \mathrm{~h}$ ), devido à clara desvantagem de operação na pequena escala. A maioria das novas unidades tem se estabelecido próximas às regiões produtoras do sul do país (grande parte delas ligadas a cooperativas agrícolas). Outra parte dos moinhos que entram no setor são ligados a empresas processadoras ou a grandes grupos econômicos.

\subsubsection{Distribuição territorial do parque moageiro brasileiro}

A Tabela 4.2, mostra o número de moinhos e a capacidade de moagem instalada por regiões e estados brasileiros em 1996.

Na região Sul concentra-se o maior número de unidades moageiras (146), porém a capacidade de moagem total desta região é inferior a da região Sudeste que possui apenas 26 moinhos e tem a maior capacidade instalada do parque nacional com 5.274.400 t/ano. 
TABELA 4.2 Localização do parque moageiro nacional e capacidade de moagem instalada por regiões e estados do Brasil - 1996

\begin{tabular}{llccc}
\hline \hline Região & Estado & $\mathrm{N}^{\circ}$ de Moinhos & $\begin{array}{c}\text { Capacidade de moagem } \\
(\mathrm{kg} / 24 \mathrm{~h})\end{array}$ & $\begin{array}{c}\text { Capacidade de } \\
\text { moagem (t/ano) }\end{array}$ \\
\hline \multirow{3}{*}{ Norte } & Amazonas & 1 & 400.000 & 120.000 \\
& Maranhão & 1 & 400.000 & 120.000 \\
& Pará & 2 & 900.000 & 270.000 \\
\cline { 2 - 5 } Total da região & 4 & 1.700 .000 & 510.000 \\
\hline \multirow{4}{*}{ Nordeste } & Ceará & 3 & 2.600 .000 & 780.000 \\
& Paraíba & 1 & 270.000 & 81.000 \\
& Pernambuco & 3 & 1.700 .000 & 510.000 \\
& Rio Grande do Norte & 1 & 330.000 & 99.000 \\
& Alagoas & 2 & 600.000 & 180.000 \\
& Bahia & 3 & 2.000 .000 & 600.000 \\
& Sergipe & 1 & 400.000 & 120.000 \\
\cline { 2 - 5 } Centro Oestal da região & 14 & 7.900 .000 & 2.370 .000 \\
& Minas Gerais & 6 & 3.050 .000 & 915.000 \\
& Distrito Federal & 1 & 350.000 & 105.000 \\
& Goiás & 1 & 400.000 & 120.000 \\
& Mato Grosso do Sul & 4 & 1.510 .000 & 453.000 \\
\cline { 2 - 5 } Sudeste & Total da região & 12 & 5.310 .000 & 1.593 .000 \\
\hline \multirow{3}{*}{ Sul } & Espirito Santo & 1 & 500.000 & 150.000 \\
& Rio de Janeiro & 5 & 4.700 .000 & 1.410 .000 \\
& São Paulo & 20 & 12.380 .000 & 3.714 .400 \\
\cline { 2 - 5 } & Total da região & 26 & 17.580 .000 & 5.274 .400 \\
\hline \hline & Paraná & 36 & 6.223 .000 & 1.866 .900 \\
& Santa Catarina & 39 & 2.859 .700 & 857.910 \\
& Rio Grande do Sul & 71 & 8.148 .260 & 2.444 .478 \\
\cline { 2 - 5 } & Total da região & 146 & 17.230 .960 & 5.169 .288 \\
\hline
\end{tabular}

Fonte: ABITRIGO (1996) Obs.1: Considerando 300 dias úteis de moagem por ano.

Na Tabela 4.3, verifica-se a distribuição absoluta destas unidades moageiras em 1996, por classe de moagem segundo as zonas de consumo ${ }^{1}$. Observa-se uma grande dispersão de tamanho de plantas nas zonas de consumo 7 e 8 , sendo que $59 \%$ das unidades da primeira zona de consumo e $27 \%$ da segunda, são moinhos com capacidade de até $50 \mathrm{t} / 24 \mathrm{~h}$. Observase ainda que, na classe 8 , a maior planta tem uma capacidade não superior a $500 \mathrm{t} / 24 \mathrm{~h}$. As maiores unidades da zona 7 concentram-se no estado de São Paulo. Nas demais zonas de

'O anexo 3 lista os moinhos brasileiros e suas localizações no mercado, por zonas de consumo. 
consumo, as menores unidades moageiras têm um tamanho mínimo de planta não inferior a $190 \mathrm{t} / 24 \mathrm{~h}$.

TABELA 4.3 Distribuição absoluta dos moinhos brasileiros por classe de capacidade de moagem, segundo as zonas de consumo, 1996

\begin{tabular}{l|l|l|l|l|l|l|l|l}
\hline \hline \multirow{2}{*}{ Classes (t/24h) } & \multicolumn{7}{|c|}{ Zonas de Consumo } \\
\hline & 1 & 2 & 3 & 4 & 5 & 6 & 7 & 8 \\
\hline Até 10 & & & & & & & & 6 \\
\hline $11-20$ & & & & & & & 2 & 7 \\
\hline $21-30$ & & & & & & & 2 & 6 \\
\hline $31-40$ & & & & & & & & 6 \\
\hline $41-50$ & & & & & & & 11 & 40 \\
\hline $51-60$ & & & & & & & 1 & 7 \\
\hline $61-70$ & & & & & & & 3 & 2 \\
\hline $71-80$ & & & & & & & 1 & 7 \\
\hline $91-100$ & & & & & & & 4 & 3 \\
\hline $121-130$ & & & & & & & & 1 \\
\hline $141-150$ & & & & & & & 1 & 1 \\
\hline $171-180$ & & & & & & & 1 & \\
\hline $191-200$ & & 1 & & & & 1 & 7 & 6 \\
\hline $231-240$ & & & & & & & 1 & 1 \\
\hline $241-250$ & & & & & & & 2 & 2 \\
\hline $261-270$ & & 1 & & & & & & \\
\hline $291-300$ & & & 3 & & & & 3 & 5 \\
\hline $321-330$ & & 1 & & & & & & \\
\hline $341-350$ & & & & & & 1 & & \\
\hline $351-360$ & & & & & & 1 & & \\
\hline $391-400$ & 3 & & 1 & 2 & & 2 & 6 & 7 \\
\hline $441-450$ & & & & & & 1 & & \\
\hline $451-460$ & & & & & & & 1 & \\
\hline $491-500$ & 1 & 1 & & 2 & 1 & 1 & 2 & 1 \\
\hline $541-550$ & & & & 1 & & & & \\
\hline $591-600$ & & & & & 2 & & 2 & \\
\hline $691-700$ & & & 1 & & & & & \\
\hline $791-800$ & & 2 & & 1 & & & & \\
\hline $991-1000$ & & 2 & 1 & & 1 & & 3 & \\
\hline $1391-1400$ & & & & & & & 1 & \\
\hline $1591-1600$ & & & & & & & 1 & \\
\hline $1991-2000$ & & & & & 1 & & & \\
\hline $2791-2800$ & & & & & & & 1 & \\
\hline Total & 4 & 8 & 6 & 6 & 5 & 7 & 56 & 110 \\
\hline \hline
\end{tabular}

Fonte: ABITRIGO (1996) 
Na Tabela 4.4, a distribuição absoluta dos moinhos brasileiros é apresentada por regiões brasileiras ${ }^{2}$.

TABELA: 4.4 Distribuição absoluta dos moinhos brasileiros por classe de capacidade de moagem, segundo as regiões brasileiras, 1996.

\begin{tabular}{|c|c|c|c|c|c|}
\hline \multirow[t]{2}{*}{ Classe(t/24h) } & \multicolumn{5}{|c|}{ Regiões Brasileiras } \\
\hline & Norte & Nordeste & Centro-Oeste & Sudeste & Sul \\
\hline Até 10 & & & & & 6 \\
\hline $11-20$ & & & & & 9 \\
\hline $21-30$ & & & & & 8 \\
\hline $31-40$ & & & & & 8 \\
\hline $41-50$ & & & & & 51 \\
\hline $51-60$ & & & & & 8 \\
\hline $61-70$ & & & & & 5 \\
\hline $71-80$ & & & & & 8 \\
\hline $91-100$ & & & & 1 & 6 \\
\hline $121-130$ & & & & & 1 \\
\hline $141-150$ & & & & 1 & 1 \\
\hline $171-180$ & & & & 1 & \\
\hline $191-200$ & & 1 & 1 & 3 & 10 \\
\hline $231-240$ & & & & 1 & 1 \\
\hline $241-250$ & & & & 1 & 3 \\
\hline $261-270$ & & 1 & & & \\
\hline $291-300$ & & 3 & & 2 & 6 \\
\hline $321-330$ & & 1 & & & \\
\hline $341-350$ & & & 1 & & \\
\hline $351-360$ & & & 1 & & \\
\hline $391-400$ & 3 & 1 & 4 & 2 & 11 \\
\hline $441-450$ & & & 1 & & \\
\hline $451-460$ & & & & 1 & \\
\hline $491-500$ & 1 & 1 & 2 & 2 & 3 \\
\hline $541-550$ & & & 1 & & \\
\hline $591-600$ & & & & 4 & \\
\hline $691-700$ & & 1 & & & \\
\hline $791-800$ & & 2 & 1 & & \\
\hline $991-1000$ & & 3 & & 3 & 1 \\
\hline $1391-1400$ & & & & 1 & \\
\hline $1591-1600$ & & & & 1 & \\
\hline $1991-2000$ & & & & 1 & \\
\hline $2791-2800$ & & & & 1 & \\
\hline Total & 4 & 14 & 12 & $\overline{26}$ & 146 \\
\hline
\end{tabular}

Fonte: ABITRIGO (1996)

${ }^{2} \mathrm{O}$ anexo 4 lista os moinhos brasileiros e suas localizações no mercado, por regiões. 
Observa-se, na região Sul, uma grande dispersão de tamanho de plantas, predominando as pequenas unidades (56\% dos moinhos, nesta região, têm capacidade de moagem de no máximo 50 t/24h). Dado que na região Sudeste não existem moinhos com menos de $91 \mathrm{t} / 24 \mathrm{~h}$, pode-se concluir que estas unidades menores localizam-se predominantemente no estado do Paraná.

Esta distribuição territorial dos moinhos brasileiros já apresentava perfil similar em 1987. Silva (1989), relaciona este fato com a formação do parque moageiro a partir, principalmente, da década de 50. A autora afirma que o grande número de moinhos situados na região Sul deve-se ao fato do produto processado ter maior custo médio de transporte, por tonelada, que o trigo em grão. Neste caso, seria mais lucrativa a localização das unidades moageiras próximas às regiões produtoras ou da Argentina (principal fornecedora do cereal importado) que dos centros consumidores. Nos estados onde não haveria produção doméstica de grão (e, portanto, o suprimento de matéria-prima seria feito basicamente por importação através de terminal portuário), a tendência seria dos moinhos localizarem-se nos centros consumidores (normalmente nas capitais de seus estados) ou na região portuária.

A distribuição absoluta e relativa dos moinhos de trigo, por classes de capacidade de moagem no Brasil, em 1987, é apresentada na Tabela 4.5. Comparando-se estes resultados com os apresentados na Tabela 4.6, para o ano de 1996, constatam-se algumas modificações no perfil do parque moageiro nacional. Enquanto em 1987, a classe modal era a dos moinhos de até 10 t/24h, em 1996 passa a ser a classe compreendida entre 41 e 50 t/24h. Além disto, nota-se a presença, em 1996, de unidades com capacidade de mais de $1.000 \mathrm{t} / 24 \mathrm{~h}$, fato que não se observava em 1987. Apesar de se constatar uma expansão da capacidade dos moinhos em 1996, em comparação ao ano de 1987, continua-se com uma grande variedade de tamanhos de moinhos no Brasil como um todo, sendo 54,46\% deles com capacidade de moagem de até $100 \mathrm{t} / 24 \mathrm{~h}$ e $45,55 \%$ com mais de $120 \mathrm{t} / 24 \mathrm{~h}$. Uma observação importante é o aumento, no período, de moinhos operando com mais de $200 \mathrm{t} / 24 \mathrm{~h}$ de moagem (eficientes tecnicamente), que passaram de 48 em 1987 para 73 em 1996. 
TABELA 4.5 Distribuição absoluta e relativa dos moinhos de trigo, por classe de capacidade de moagem - Brasil, 1987.

\begin{tabular}{lcccc}
\hline \hline Classes(t/24h) & FA $_{i}$ & SUM $\left(\mathrm{FA}_{\mathrm{i}}\right)$ & $\mathrm{Fr}_{\mathrm{i}} \%$ & $\mathrm{SUM}\left(\mathrm{FR}_{\mathrm{i}}\right) \%$ \\
\hline $0-10$ & 31 & 31 & 17,3 & 17,3 \\
$10-20$ & 22 & 53 & 12,3 & 29,6 \\
$20-30$ & 22 & 75 & 12,3 & 41,99 \\
$30-40$ & 12 & 87 & 6,7 & 48,6 \\
$40-50$ & 6 & 93 & 3,3 & 51,9 \\
$50-80$ & 16 & 109 & 8,9 & 60,8 \\
$80-110$ & 8 & 117 & 4,5 & 65,3 \\
$110-140$ & 7 & 124 & 3,9 & 69,2 \\
$140-170$ & 4 & 128 & 2,2 & 71,4 \\
$140-150$ & 2 & 113 & 0,99 & 55,96 \\
$170-200$ & 3 & 131 & 1,7 & 73,1 \\
$200-250$ & 7 & 138 & 3,9 & 77,0 \\
$250-300$ & 6 & 144 & 3,3 & 80,3 \\
$300-3500$ & 7 & 151 & 3,9 & 84,2 \\
$350-400$ & 7 & 158 & 3,9 & 88,1 \\
$400-500$ & 5 & 163 & 2,8 & 90,9 \\
$500-600$ & 5 & 168 & 2,8 & 93,7 \\
$600-700$ & 2 & 170 & 1,1 & 94,8 \\
$700-800$ & 1 & 171 & 0,6 & 95,4 \\
$800-900$ & 1 & 172 & 0,6 & 96,0 \\
$900-1000$ & 1 & 173 & 0,6 & 96,6 \\
$1000-1200$ & 6 & 179 & 3,3 & 100,0 \\
\hline \hline
\end{tabular}

Fonte: SUNAB, capacidade do parque moageiro nacional, considerando o resultado das provas físicas de moagem; ano 1988 - Extraído de Silva (1989)

Legendas: $\mathrm{FA}_{\mathrm{i}}=$ Freqüência absoluta dos moinhos da classe $\mathrm{i}$;

$\operatorname{SUM}\left(\mathrm{FA}_{\mathrm{i}}\right)=$ Freqüência absoluta acumulada dos moinhos da classe $\mathrm{i}$;

$\mathrm{FR}_{\mathrm{i}}=$ Freqüência relativa dos moinhos da classe $\mathrm{i}$;

$\operatorname{SUM}\left(\mathrm{FR}_{\mathrm{i}}\right)=$ Freqüência relativa acumulada dos moinhos da classe $\mathrm{i}$. 
TABELA 4.6 Distribuição absoluta e relativa dos moinhos de trigo por classe de capacidade moagem - Brasil, 1996.

\begin{tabular}{|c|c|c|c|c|}
\hline Classes $(\mathrm{t} / 24 \mathrm{~h})$ & $\mathrm{FAi}$ & SUM (FAi) & $\mathrm{Fr}_{\mathrm{i}} \%$ & SUM (FRi)\% \\
\hline Até 10 & 6 & 6 & 2,9700 & 2,9700 \\
\hline $11-20$ & 9 & 15 & 4,4554 & 7,4254 \\
\hline $21-30$ & 8 & 23 & 3,9604 & 11,3858 \\
\hline $31-40$ & 8 & 31 . & 3,9604 & 15,3462 \\
\hline $41-50$ & 51 & 82 & 25,2475 & 40,5937 \\
\hline $51-60$ & 8 & 90 & 3,9604 & 44,5541 \\
\hline $61-70$ & 5 & 95 & 2,4752 & 47,0293 \\
\hline $71-80$ & 8 & 103 & 3,9604 & 50,9897 \\
\hline $91-100$ & 7 & 110 & 3,4653 & 54,4550 \\
\hline $121-130$ & 1 & 111 & 0,4950 & 54,9500 \\
\hline $141-150$ & 2 & 113 & 0,9901 & 55,9401 \\
\hline $171-180$ & 1 & 114 & 0,4950 & 56,4351 \\
\hline $191-200$ & 15 & 129 & 7,4257 & 63,8608 \\
\hline $231-240$ & 2 & 131 & 0,9901 & 64,8509 \\
\hline $241-250$ & 4 & 135 & 1,9802 & 66,8311 \\
\hline $261-270$ & 1 & 136 & 0,4950 & 67,3261 \\
\hline $291-300$ & 11 & 147 & 5,4455 & 72,7716 \\
\hline $321-330$ & 1 & 148 & 0,4950 & 73,2666 \\
\hline $341-350$ & 1 & 149 & 0,4950 & 73,7616 \\
\hline $351-360$ & 1 & 150 & 0,4950 & 74,2566 \\
\hline $391-400$ & 21 & 171 & 10,3960 & 84,6526 \\
\hline $441-450$ & 1 & 172 & 0,4950 & 85,1476 \\
\hline $451-460$ & 1 & 173 & 0,4950 & 85,6426 \\
\hline $491-500$ & 9 & 182 & 4,4554 & 90,0980 \\
\hline $541-550$ & 1 & 183 & 0,4950 & 90,5930 \\
\hline $591-600$ & 4 & 187 & 1,9802 & 92,5732 \\
\hline $691-700$ & 1 & 188 & 0,4950 & 93,0682 \\
\hline $791-800$ & 1 & 189 & 0,4950 & 93,5632 \\
\hline $991-1000$ & 3 & 192 & 1,4851 & 95,0483 \\
\hline $1391-1400$ & 7 & 199 & 3,4653 & 98,5136 \\
\hline $1591-1600$ & 1 & 200 & 0,4950 & 99,0086 \\
\hline $1991-2000$ & 1 & 201 & 0,4950 & 99,5036 \\
\hline $2791-2800$ & 1 & 202 & 0,4950 & 100,00 \\
\hline
\end{tabular}

Fonte: ABITRIGO (1996)

Legendas: $F A_{i}=$ Freqüência absoluta dos moinhos da classe $i$;

$\operatorname{SUM}\left(\mathrm{FA}_{\mathrm{i}}\right)=$ Freqüência absoluta acumulada dos moinhos da classe $\mathrm{i}$;

$\mathrm{FR}_{\mathrm{i}}=$ Freqüência relativa dos moinhos da classe $\mathrm{i}$;

$\operatorname{SUM}\left(\mathrm{FR}_{\mathrm{i}}\right)=$ Freqüência relativa acumulada dos moinhos da classe $\mathrm{i}$. 
4.1.3 Moinhos ligados a cooperativas de produtores

A Tabela 4.7 mostra o número de moinhos ligados a cooperativas de produtores agrícolas e o total da capacidade de moagem por estado, em $1996^{3}$.

Com a desregulação do mercado aumentaram o número de moinhos associados a estas cooperativas, passando de $16 \mathrm{em} 1987$ para $20 \mathrm{em} \mathrm{1996,} \mathrm{a} \mathrm{maioria} \mathrm{delas} \mathrm{situadas} \mathrm{no} \mathrm{Rio}$ Grande do Sul. No entanto, a capacidade de moagem destas unidades representam apenas $2,71 \%$ do total do potencial da oferta brasileira. Com relação ao tamanho das plantas, tem-se: uma unidade com capacidade de moagem de $200 \mathrm{t} / 24 \mathrm{~h}$, uma de $150 \mathrm{t} / 24 \mathrm{~h}$, sete entre 60 e 80 $\mathrm{t} / 24 \mathrm{~h}$ e 15 com capacidades menores que $50 \mathrm{t} / 24 \mathrm{~h}$.

TABELA 4.7 Número de moinhos ligados a cooperativas de produtores e capacidade de moagem total por estado - Brasil, 1996

\begin{tabular}{lcc}
\hline \multicolumn{1}{c}{ Estado } & $\mathrm{N}^{\circ}$ de moinhos & Capacidade de moagem $(\mathrm{kg} / 24 \mathrm{~h})$ \\
\hline Paraná & 04 & 350.000 \\
Rio Grande do Sul & 14 & 576.060 \\
Santa Catarina & 06 & 420.000 \\
\hline Total & 20 & 1.346 .060 \\
\hline
\end{tabular}

Fonte: ABITRIGO (1996)

${ }^{3}$ No anexo 5 lista-se a relação completa dos moinhos brasileiros ligados a cooperativas, por estados. 
4.1.4 Evolução dos índices de concentração técnica na indústria de moagem

A fim de analisar a estrutura industrial da moagem em termos de concentração técnica ${ }^{4}$ (ou seja, das unidades de produção ou plantas) e verificar sua evolução, calculou-se os índices de Hirschman-Herfindhal $(\mathrm{HH})$ e a razão de concentração da maior (C1) e das quatro maiores empresas (C4), comparando-os com os índices encontrados por Silva (1989), para o ano de 1987. Para tanto, adotou-se o mesmo procedimento da autora, na delimitação do mercado de atuação das unidades moageiras, ou seja dentro das zonas de consumo estipuladas à época da regulação, haja visto que os moinhos atuam, predominantemente, nos mercados regionais.

A Tabela 4.8 resume os resultados encontrados em 1996 e os calculados por Silva (1989), para o ano de.1987.

Com relação ao índice 'HH' verifica-se:

1) Uma redução, não significativa, no valor do mesmo, de 1987 para 1996, nas zonas de consumo 1, 3 e 5, porém, com a concentração regional continuando elevada ${ }^{5}$. Nas zonas 3 e 5 estas reduções acompanharam o crescimento do número de moinhos.

2) Redução mais significativa no valor de 'HH', nas zonas 2, 4 e 6, diminuindo a concentração. Estas reduções podem ter sido ocasionadas, tanto pelo aumento do número de unidades moageiras no mercado quanto pela expansão de capacidade das unidades menores. Na zona 7, o aumento do número de moinhos em operação, e na 8, o aumento da escala de operação das unidades menores, podem ser explicativas para a redução (pequena) do índice.

${ }^{4}$ Classificação utilizada por Labini (1980). Ver, capítulo 3, página 53 do presente trabalho.

${ }^{5}$ A literatura tem utilizado como referência o valor de "HH" $=0,18$ estabelecido pela lei antitrust americana, a partir do qual se tornam proibitivas as fusões ou incorporações (Mendes et. al., 1994) 
TABELA 4.8 Evolução da concentração técnica na indústria brasileira de moagem de trigo, segundo a capacidade real em 1987 e a capacidade instalada em 1996, por zona de consumo.

\begin{tabular}{|c|c|c|c|c|c|c|c|c|}
\hline \multirow[t]{2}{*}{$\begin{array}{l}\text { ZONAS DE } \\
\text { CONSUMO }\end{array}$} & \multicolumn{2}{|c|}{$\begin{array}{c}\mathbf{N}^{\circ} \mathbf{D E} \\
\text { MOINHOS }\end{array}$} & \multicolumn{2}{|c|}{ HH } & \multicolumn{2}{|c|}{ C1 (\%) } & \multicolumn{2}{|c|}{$\mathrm{C} 4(\%)$} \\
\hline & 1987 & 1996 & 1987 & 1996 & 1987 & 1996 & 1987 & 1996 \\
\hline 1 & 4 & 4 & 0,26 & 0,25 & 31,63 & 29,41 & 100,00 & 100,00 \\
\hline 2 & 7 & 8 & 0,21 & 0,16 & 33,62 & 20,41 & 77,02 & 73,47 \\
\hline 3 & 5 & 6 & 0,22 & 0,21 & 33,31 & 33,33 & 85,16 & 80,00 \\
\hline 4 & 5 & 6 & 0,22 & 0,18 & 27,97 & 25,40 & 88,20 & 74,60 \\
\hline 5 & 6 & 5 & 0,30 & 0,27 & 48,72 & 42,55 & 89,25 & 89,36 \\
\hline 6 & 4 & 7 & 0,38 & 0,15 & 44,70 & 18,80 & 100,00 & 65,79 \\
\hline 7 & 38 & 56 & 0,07 & 0,05 & 14,53 & 15,05 & 55,76 & 36,55 \\
\hline 8 & 110 & 111 & 0,03 & 0.05 & 9,21 & 4,54 & 24,70 & 15,44 \\
\hline
\end{tabular}

Fonte: 1987: Silva (1989), com base na Portaria SUPER n ${ }^{\circ} 1471$ de 20/12/87. 1996: ABITRIGO (1996)

Outra indicação importante que se pode inferir é quanto à redução na dispersão de tamanho das plantas em algumas zonas de consumo. Como já verificado no capítulo 3,0 índice 'HH' baseia-se na participação de cada firma no total do mercado e varia entre 0 e 1. Quanto mais próximo de zero, maior é o grau de atomização das empresas no mercado; e quanto mais próximo de 1, maior a concentração. Se $\mathrm{HH}=1$, trata-se de um monopólio e se $\mathrm{HH}=1 / \mathrm{n}$ (onde n representa o número de empresas neste mercado), as empresas teriam igual participação no mercado. Assim, por exemplo, se em um mercado houvesse 10 firmas, cada uma delas com o mesmo tamanho de planta, o índice 'HH' teria o valor de $1 / \mathrm{n}=1 / 10=0,1$. 
Calculando-se, portanto, estes valores de referência $(1 / n)$, para as zonas de consumo 1,4 e 7 tem-se: $\mathrm{HH}_{1}=1 / 4=0,25 ; \mathrm{HH}_{4}=1 / 6=0,17$ e $\mathrm{HH}_{7}=1 / 7=0,14$. Comparandose estes resultados com os valores encontrados para estas zonas, para o ano de $1996 \mathrm{de}$ $\mathrm{HH}_{1}=0,25 ; \mathrm{HH}_{4}=0,18$ e $\mathrm{HH}_{7}=0,15$, poder-se-ía concluir que as firmas em cada um destes mercados têm plantas de tamanho muito similares.

Em relação à participação da maior planta $(\mathrm{Cl})$, verifica-se uma redução dos índices nas zonas de consumo 1, 2, 4, 5, 6 e 8. Nas zonas de consumo 1, 2 e 4 estas reduções ocorreram, muito provavelmente, devido à ampliação da capacidade dos moinhos e/ou a uma redução na dispersão no tamanho das plantas. Isto é mais significativo na zona de consumo número 1 , onde o potencial de oferta de cada uma das quatro empresas no mercado é praticamente o mesmo (se, em um mercado em que atuam apenas quatro empresas, cada uma delas tiver a mesma participação no mercado, o índice $\mathrm{Cl}$ deveria ser 0,25 , valor muito próximo do encontrado de 0,29 para esta zona de consumo). A redução mais significativa, porém, foi registrada na zona 6 , onde a participação da maior empresa na oferta total caiu de $44,7 \%$ para $18,8 \%$ devido, principalmente, à entrada de mais três moinhos de grande porte neste mercado. Nas zonas 3 e 7 verifica-se um pequeno aumento da participação da firma líder em relação às demais.

Com relação à participação das quatro maiores empresas (C4) em 1996, observa-se que, na zona de consumo 1, este índice continua com o mesmo valor de 1987 (100\%), tendo em vista que ainda operam, neste mercado, apenas 04 empresas. Com exceção desta e da zona 5 , que teve um aumento insignificante no valor do índice $\mathrm{C} 4$, as demais regiões tiveram uma redução da participação das quatro maiores empresas na capacidade total.

Conclui-se, de forma geral, que nas zonas de consumo 1 a 5 , apesar da queda dos índices, a concentração continuou elevada em 1996. Na zona de consumo 6, devido ao aumento de 75\% no número de moinhos de 1987 para 1996 (de 4 unidades para 7), os índices reduziram-se significativamente, indicando uma menor concentração técnica neste mercado em relação a 1987. 
Saliente-se, porém, que os índices de concentração técnica utilizados e as conclusões que se inferem a partir deles devem ser analisadas com certo cuidado. Neste caso, ao se usar para o cálculo destes índices a capacidade de moagem instalada dos moinhos, tem-se idéia da oferta potencial destas firmas, haja visto que as unidades moageiras podem não estar utilizando de toda sua capacidade instalada e estar operando com certo grau de capacidade ociosa. Um exemplo, neste caso, poderia ser esclarecedor. Para simplificar, supõe-se um mercado em que operem apenas 2 moinhos, com capacidade instalada de 800 e $200 \mathrm{t} / 24 \mathrm{~h}$, sendo que a maior unidade opera com $100 \%$ de sua capacidade instalada e a menor com apenas $50 \%$. Ao se considerar para o cálculo de $\mathrm{Cl}$ e $\mathrm{HH}$ a capacidade instalada, ter-se-ia $\mathrm{Cl}=80$ e $\mathrm{HH}=0,68$. Considerando-se, porém, a oferta real dos moinhos, os índices seriam respectivamente 88,9 e 0,8 , ou seja, no segundo caso em que se considera a capacidade efetiva dos moinhos, os índices são mais elevados.

Esta é uma limitação do estudo, uma vez que os dados disponíveis são os da capacidade instalada do parque moageiro nacional e não da capacidade efetiva. Contudo, estes índices fornecem uma idéia do potencial de poder de mercado das firmas grandes. Caso os moinhos menores operem com capacidade ociosa superior a dos maiores, se poderia supor que a concentração de mercado seria ainda maior do que sinalizam os índices apresentados.

\subsubsection{A concentração econômica na indústria de moagem}

Parcela considerável das empresas de moagem no Brasil são associadas ou pertencem a grandes grupos econômicos. Esta situação já se verificava, com bastante intensidade, à época do mercado regulado, tendo se ampliado após 1990, principalmente com os processos intensos de fusões e incorporações ocorridos no Brasil nesta década. Silva (1989), afirmava que os moinhos associados a grupos econômicos em 1987, poderiam ser 
considerados moinhos quase-firmas. De acordo com Williamson $(1971)^{6}$, citado pela autora, este conceito indica que a unidade é independente da direção central no caso das decisões correntes, mas é subordinada a ela no caso do processo de crescimento. Silva (op. cit.), associa a existência destes grupos econômicos no setor à estratégia de crescimento das firmas e, ao fato de ser mais eficiente a operação de várias plantas adequadamente distribuídas, que reduziriam os custos de distribuição e beneficiaria as firmas pelas economias pecuniárias, provenientes de obtenção de recursos financeiros na operação em larga escala.

A Tabela 4.9 mostra os principais grupos econômicos no setor em $1996^{7}$ e no Anexo 2 têm-se as empresas pertencentes a estes grupos e sua localização no mercado brasileiro.

Registra-se, no ano de 1996, um total de 46 moinhos ligados a grandes grupos com uma capacidade total diária de moagem de 23.490 toneladas, o que representa $47,24 \%$ de toda a capacidade do parque moageiro nacional. O conglomerado Santista Alimentos S.A. do gnupo Bunge Brasil (grupo que atua em atividades diversas) é o líder do mercado, com 11 moinhos que somam uma capacidade de moagem de 7.650 toneladas diárias, o que representa $15,39 \%$ da capacidade total do Brasil em 1996. Outros grupos de destaque no setor são: o J. Macedo (que atua nos ramos de bebidas e fumo, mecânica, veículos e peças, química e petroquímica, fábricas de biscoitos e holdings) e o Pena Branca (holdings, fast foods, alimentos e serviços gerais), que possuem 9 e 6 moinhos com participações de 8,85\% e $5,53 \%$ da capacidade de moagem brasileira, respectivamente

\footnotetext{
${ }^{6}$ WILLIANSON, O. E. Managerial discretion, organization form and the multi-division hypothesis. In: MARRIS, R. \& WOOD, A. (orgs.) The Corporate Economy. Cambridge: Harvard University Press, 1971.

${ }^{7}$ Segundo dados fornecidos pela Associação Brasileira da Indústria de trigo (1996), e outras informações complementares da revista Balanço Anual da Gazeta Mercantil (Vários números)
} 
TABELA 4.9 Principais grupos econômicos na moagem de trigo - Brasil, 1996.

\begin{tabular}{|c|c|c|c|c|}
\hline Grupo Industrial & $\mathrm{N}^{\circ}$ de Moinhos & $\begin{array}{l}\text { Capacidade de Moagem } \\
\mathrm{kg} / 24 \mathrm{~h} \mathrm{em} 1996\end{array}$ & $\begin{array}{c}\text { Participação \% } \\
\text { na capacidade total } \\
\text { do Brasil } \\
\end{array}$ & Posição \\
\hline Bunge Brasil $^{8}$ (Santista) & 11 & 7.650 .000 & 15,39 & 1 \\
\hline J. Macedo & 9 & 4.400 .000 & 8,85 & 2 \\
\hline Pena Branca & 6 & 2.750 .000 & 5,53 & 3 \\
\hline Anaconda & 2 & 2.000 .000 & 4,02 & 4 \\
\hline Ocrim & 4 & 1.340 .000 & 2,70 & 5 \\
\hline Vera Cruz & 2 & 1.200 .000 & 2,41 & 6 \\
\hline Indígena & 3 & 1.100 .000 & 2,21 & 7 \\
\hline Buaiz & 2 & 1.000 .000 & 2,01 & 8 \\
\hline Garota & 2 & 800.000 & 1,61 & 9 \\
\hline Dallas & 2 & 650.000 & 1,31 & 10 \\
\hline Tondo & 3 & 600.000 & 1,21 & 11 \\
\hline Total dos Grupos & 46 & 23.490 .000 & 47,24 & \\
\hline$\overline{\text { BRASIL }}$ & 202 & 49.720 .960 & 100 & \\
\hline
\end{tabular}

Fonte: ABITRIGO (1996)

Ao comparar-se as Tabelas 4.9 e 2.12 (apresentada no capítulo 2), a fim de verificar a evolução da concentração econômica no setor de 1987 a 1996, percebe-se uma redução da participação dos grandes grupos no total da capacidade do parque moageiro nacional de $54,83 \%$ em 1987 , para $47,24 \%$ em 1996 , o que leva a supor uma redução no período considerado. Esta constatação, no entanto, não pode ser considerada como verdadeira, por dois motivos: em primeiro lugar, devido ao fato que na tabela 2.12, apresentada por Mendes et al. (1994), considera-se para o cálculo da participação dos grandes grupos, no total da capacidade de moagem brasileira, a capacidade total dos moinhos registrada na SUNAB, que ficava muito aquém da real capacidade do parque moageiro nacional.

\footnotetext{
${ }^{8}$ Grupo estrangeiro que está sob o controle acionário da Bunge International Ltda, origem: Bermudas Capital argentino.(Revista Balanço Anual da Gazeta Mercantil, 1996)
} 
Para comprovar isso, basta comparar a capacidade de moagem total do Brasil e dos grandes grupos considerada em 1987, de 17.630 e 9.667 toneladas diárias respectivamente, com as de 1996 de 49.721 e 23.490 . Em segundo lugar, porque as expansões dos grandes grupos nos últimos 6 anos, principalmente através dos processos de fusões e incorporações, têm sido bastante intensas.

Além dos listados na Tabela 4.9, há registros de vários outros grupos econômicos financeiros que diversificam suas atividades em direção ao setor de moagem. Estes não foram listados, porque a maioria deles possui apenas um moinho. No entanto, cabe destacar alguns deles:

- Grupo São Jorge (atua nos ramos, têxtil, laticínios, comércio e indústria) controla as Indústrias Reunidas São Jorge.

- Grupo Jauense (atividades diversas) controlando a Cia. Jauense Industrial.

- G. Jereissati (holdings, construções, bebidas e fumo, metalurgia, alimentos e serviços gerais) controla o Grande Moinho Cearense.

- Cargill Agrícola (conglomerado alimentício), proprietária do moinho São Valentim Agroindustrial.

Algumas alterações importantes foram verificadas na configuração destes grandes grupos econômicos do setor de 1987 (Tabela 2.12) para 1996 (Tabela 4.9). O grupo Carfepe, que tinha 2 moinhos em 1987 (um em Mato Grosso do Sul e outro em Uberlândia), vendeu estas duas unidades, sendo uma delas para o conglomerado Santista Alimentos S.A. do grupo Bunge Brasil. O grupo Buaiz paralisou as atividades de um de seus moinhos em Petropolis/RJ, porém continua com 2 unidades em operação, uma em Vitória/ES e outra em Três Rios/RJ, que podem cobrir o mercado do moinho inativo. $\mathrm{O}$ grupo Dallas surge no setor após a desregulação com 2 unidades em Mato Grosso do Sul. $\mathrm{O}$ grupo Tondo adquiriu mais um moinho, após 1994, em Caxias do Sul/RS. Em 1993, a Sadia Concórdia formalizou a fusão com o grupo J. Macedo S.A. para ampliar sua participação no mercado de farinhas e massas alimentícias, surgindo assim a Lapa Alimentos do grupo J. Macedo (3 moinhos da 
Sadia são envolvidos na transação, um no Rio Grande do Sul e dois em São Paulo, passando ao controle da J. Macedo) $)^{9}$.

Os dois grupos que mais cresceram no setor foram, o Bunge Brasil, através de seu conglomerado Santista Alimentos S.A., e o J. Macedo. Silva (1989), registrava em 1987 os dois grupos com 5 unidades moageiras cada um, sendo que em 1996, eles detinham o controle de 11 e 9 moinhos, respectivamente.

O conglomerado Santista tem moinhos nos estados da Paraíba, Pernambuco, Rio de Janeiro, São Paulo, Rio Grande do Sul, Santa Catarina e Mato Grosso do Sul, enquanto o grupo J. Macedo no Ceará, Maceió, Alagoas, Bahia, São Paulo e nos três estados do sul do pais (vide anexo 6). A maioria dos outros grupos listados, também tem moinhos espalhados por todas as regiões brasileiras. Esta busca de novos mercados, por parte dos grandes grupos, poderia comprovar a tese de que os moinhos competem a nível regional, à medida em que há claras vantagens em ter-se moinhos em atuação nos diversos mercados regionais, ao invés de apenas grandes unidades abastecendo o mercado nacional.

A Santista, além das várias aquisições que fez ao longo dos anos 90 , tanto de moinhos como de indústrias de massas, pães e bolos, tem utilizado como estratégia de expansão o arrendamento de algumas unidades moageiras ${ }^{10}$. Em novembro de 1996, a Santista assinou uma promessa de compra da Ideal Alimentos, moinho da Bahia, dando prosseguimento a esta sua estratégia de expansão no setor.

Esta expansão dos grupos econômicos deriva também, de certa forma, de suas vantagens financeiras, além do fato de manterem atividades bastante diversificadas em vários mercados, principalmente nos de transformação de derivados do trigo.

\footnotetext{
${ }^{9}$ Na relação dos grupos econômicos fornecida pela ABITRIGO, as duas unidades da Lapa Alimentos de São Paulo constam no grupo J. Macedo, enquanto a unidade de Marcelino Ramos, no RS, consta como Sadia Concórdia S.A.

${ }^{10}$ Este conglomerado aluga, atualmente, duas unidades moageiras no Sul do País (com capacidade de 200 e 400 toneladas/24hs) sendo que, até o final de 1996, estava mantendo uma delas com as atividades paralisadas. (informações coletadas na pesquisa)
} 
Cabe destacar que muito provavelmente, estas estratégias de aquisição de firmas na indústria através de fusões e aquisições ${ }^{11}$ vêm ocorrendo na busca de economias de escala, de escopo e estratégias competitivas, por parte das firmas líderes. Grandes firmas normalmente só compram outras, se os custos de aquisição forem menores que o investimento necessário à expansão de sua própria capacidade produtiva ou para a instalação de uma nova unidade. Além disso, levam em consideração a redução da margem de lucro que resultaria de uma possível redução de preços requerida para aumentar ou sustentar sua parcela do mercado, caso a outra firma continue operando.

O progresso técnico, advindo da maior escala e do aproveitamento das vantagens financeiras dos grandes grupos, também é uma forma das firmas líderes eliminarem seus concorrentes, à medida que reduz seus custos, aumentando suas margens de lucro e o excedente de acumulação interna, possibilitando a redução de preços.

4.1.6 O grau de ociosidade da indústria e o potencial de crescimento da demanda de mercado.

O consumo anual de trigo no Brasil em $1995^{12}$, foi de 8.238 .000 toneladas, sendo 8.000.000 toneladas utilizadas no consumo industrial e 238.000 como semente (Tabela 4.10). Do trigo processado pelos moinhos, em média $76 \%$ é transformado em farinha para consumo domestico e industrial (industrias de panificação, massas e biscoitos), e $24 \%$ em farelo, que é utilizado basicamente pelas indústrias de ração ${ }^{13}$. Com estes dados de consumo industrial e da capacidade de moagem instalada do parque moageiro nacional, é possível calcular-se a capacidade ociosa da indústria.

\footnotetext{
${ }^{11}$ O Conselho Administrativo de Defesa Econômica (CADE), através da Lei Antitruste brasileira, de $11 / 06 / 94$, estabelece regras para as configurações industriais e para as operações de fusão e aquisição de empresas.

${ }^{12}$ Utilizou-se o dado de 1995 , tendo em vista os anos seguintes serem estimativas e dados preliminares.

${ }^{13}$ Segundo pesquisa feita pela R.C.W. Consultores de São Paulo/SP.
} 
TABELA 4.10 Balanço de Oferta e Demanda de Trigo no Brasil - 1987/88 a 1996/97 (em 1.000 toneladas).

\begin{tabular}{ccccccccc}
\hline \hline Ano/Safra & $\begin{array}{c}\text { Quantidade } \\
\text { inicial }\end{array}$ & Produção & Importação & Suprimento & $\begin{array}{c}\text { Consumo } \\
\text { Industrial }\end{array}$ & $\begin{array}{c}\text { Consumo } \\
\text { Semente }\end{array}$ & $\begin{array}{c}\text { Cons. } \\
\text { total }\end{array}$ & $\begin{array}{c}\text { Estoque } \\
\text { passag. }\end{array}$ \\
\hline $87 / 88$ & $1.807,0$ & $6.127,0$ & 2.028 & 9.962 & 7.400 & 671 & 8.071 & 1.891 \\
$88 / 89$ & $1.891,0$ & $5.847,0$ & 852 & 8.590 & 6.900 & 642 & 7.542 & 1.048 \\
$89 / 90$ & $1.048,0$ & $5.479,0$ & 1.522 & 8.049 & 6.600 & 474 & 7.074 & 975 \\
$90 / 91$ & 975,0 & $3.304,0$ & 2.849 & 7128 & 6.400 & 377 & 6.777 & 351 \\
$91 / 92$ & 351,0 & $3.078,0$ & 5.208 & 8.637 & 7.100 & 332 & 7.432 & 1.205 \\
$92 / 93$ & $1.205,0$ & $2.739,0$ & 5.913 & 9.857 & 7.500 & 308 & 7.808 & 2.049 \\
$93 / 94$ & $2.049,0$ & $2.098,0$ & 5.512 & 9.659 & 7.600 & 286 & 7.886 & 1773 \\
$94 / 95$ & $1.773,0$ & $2.138,0$ & 6.487 & 10.398 & 8.000 & 238 & 8.238 & 2.160 \\
$95 / 96$ & $2.160,0$ & $1.524,0$ & 5.221 & 8.905 & 7.900 & 254 & 8.154 & 751 \\
$96 / 97$ & 751,0 & $3.001,0$ & 4.948 & 8.700 & 7.700 & 350 & 8.050 & 650 \\
\hline \hline
\end{tabular}

Fonte: CONAB, CTRIN, DECEX, ABRASEM, Moinhos E Tradings - IEA/SP (1996)

95/96 = preliminares $\quad$ 96/97 = estimativa

Pela Tabela 4.11, pode-se verificar a ocorrência desta capacidade ociosa da indústria de moagem no Brasil e em suas regiões. $O$ cálculo da capacidade ociosa por regiões brasileiras é baseada nas estimativas de consumo percentual de farinha de trigo por regiōes brasileiras, feitas pela empresa de consultoria R.C.W. de São Paulo/SP ${ }^{14}$.

TABELA 4.11 Capacidade ociosa do pargue moageiro nacional, por regiões - Brasil, 1996.

\begin{tabular}{lcccc}
\hline \hline Regiões & $\begin{array}{c}\text { Capacidade de } \\
\text { moagem (t/ano) }\end{array}$ & $\begin{array}{c}\text { Demanda regional } \\
(\%)\end{array}$ & $\begin{array}{c}\text { Consumo estimado } \\
\text { em 1995 }\end{array}$ & $\begin{array}{c}\text { Capacidade ociosa } \\
(\%)\end{array}$ \\
\hline Norte & 510.000 & 4 & 320.000 & 59,38 \\
Nordeste & 2.370 .000 & 20 & 1.600 .000 & 48,13 \\
Centro-Oeste & 1.593 .000 & 26 & 2.080 .000 & - \\
Sudeste & 5.274 .000 & 37 & 2.960 .000 & 78,18 \\
Sul & 5.169 .288 & 13 & 1040.000 & 397,05 \\
\hline Brasil & 14.916 .288 & 100 & 8.000 .000 & 86,45 \\
\hline \hline
\end{tabular}

Fonte: ABITRIGO, CONAB, R.C.W. Consultoria - (1996).

\footnotetext{
${ }^{14}$ Estas estimativas são apresentadas em termos percentuais para as regiões brasileiras, com exceção das regiões Sudeste e Sul que foram agnupadas, pelos consultores, em apenas um percentual (50\% do consumo para as duas regiões). Para o desdobramento fez-se uma média ponderada com as populações regionais publicadas no censo demográfico de 1991 do IBGE, considerando-se ainda que não há diferenças significativas nos padrões de consumo das duas regiões.
} 
Percebe-se uma grande capacidade ociosa da indústria brasileira de moagem de trigo (86,45\%), em 1996. A região que apresenta maior índice de ociosidade é a Sul, com $397,05 \%$, enquanto a Centro-Oeste tem uma demanda superior ao seu potencial de oferta, o que permite supor que esteja sendo abastecida por moinhos de outras regiões. A alta capacidade ociosa dos moinhos do Sul do País pode ser decorrência do grande número de pequenos moinhos nestes três estados que, muito provavelmente, apresentam um nível de capacidade ociosa superior ao das maiores unidades.

$\mathrm{O}$ nível de consumo per capita brasileiro de trigo ainda é relativamente baixo. $\mathrm{O}$ relatório de 1992 do Instituto Interamericano de Cooperação para a Agricultura (IICA), estimava-o em torno de $45 \mathrm{~kg}$ a $60 \mathrm{~kg}$, enquanto o nível argentino estava em torno de $130 \mathrm{~kg}$. De fato, admitindo-se um consumo de 8.000.000 t/ano de trigo para o Brasil em 1995 e a população brasileira registrada no censo demográfico de 1991, pela Fundação Instituto Brasileiro de Geografia e Estatística (IBGE) de 146.825.475, pode-se calcular um consumo per capita próximo de $54,5 \mathrm{~kg}$. Considerando-se que, com a estabilização da economia, poder-se-ía atingir no Brasil, o mesmo nível de consumo da Argentina, ter-se-ía então, um consumo anual superior a 19 milhões de toneladas de trigo (146.825.475 x 130), superior a capacidade atual instalada do parque moageiro nacional de 14,9 milhões de toneladas/ano. Conclui-se, portanto, que a atual capacidade instalada do parque moageiro nacional está, ainda, muito aquém da potencial expansão da demanda.

Diante disto, é possível supor que as grandes firmas planejem operar com certo nível de capacidade ociosa, destinada principalmente a permitir respostas imediatas a aumentos ocasionais ou a uma expansão permanente da demanda. Segundo Guimarães (1987), uma firma só realizará investimentos em expansão diante da expectativa de um acréscimo da demanda que acarrete um aumento permanente do grau de utilização da capacidade, elevando-o acima do planejado. Nada obstante, como o ritmo de expansão da demanda pode ser lento e, dado os custos de sustentar-se durante muito tempo operando com capacidade ociosa, é possível que esta situação seja insustentável para as pequenas unidades que, além da 
baixa capacidade financeira, não tem as vantagens de custos das firmas que operam em maior escala, nem tão pouco as da ligação com os grandes grupos econômico-financeiros.

\subsubsection{Segmentação do mercado consumidor e diferenciação de produtos}

A economia de mercado que se estabeleceu, após a desregulação do setor tritícola, abriu novas alternativas de investimentos às empresas de moagem no Brasil. A liberação dos tipos e preços das farinhas e derivados de trigo, por exemplo, possibilitou a implementação de estratégias de segmentação de mercado que antes não eram possíveis no mercado regulado. Como observa Farina (1993, p. 3):

"Derivados de trigo exigem caracteristicas especificas da farinha para que tenham boa qualidade e se obtenha adequada produtividade no processo de transformação industrial. Grosso modo pode-se dizer que pães exigem um trigo "semi-duro", biscoitos exigem um trigo "soft", enquanto massas exigem mais glúten, o chamado trigo "durum". Na verdade cada receita pode exigir um "blend" especifico de farinha, estando ai uma importante fonte de diferenciação da indústria".

Os grandes moinhos ofertam hoje vários tipos de farinha, cada uma delas destinada à produção de produtos diferenciados que atendem a diferentes segmentos de mercado. As massas de grano duro, por exemplo, são de muito melhor qualidade e podem ser vendidas para consumidores das classes de renda mais elevadas, que poderiam estar dispostos a pagar um preço mais elevado por um produto de qualidade superior.

A importância desse tipo de diferenciação está no seu efeito sobre a procura do produto pelo consumidor. A diferenciação de produtos torna a curva de demanda do consumidor menos elástica, possibilitando a firma detentora do produto ter um relativo poder de aumentar os seus preços para além dos vigentes em concorrência. 
Como salientado, é necessário, entretanto, que o consumidor perceba a diferença entre as várias marcas e as vantagens de um tipo de produto em relação a outro. Neste sentido, campanhas publicitárias persuasivas poderiam ser eficientes, no sentido de convencer o consumidor das vantagens do produto. Porém, a empresa só fará estas despesas se forem menores que a vantagem adicional de vender o produto diferenciado. Nada obstante, como observa Farina e Zylbersztajn (1992, p. 76):

"A dinâmica das cadeias agroindustriais está fortemente condicionada pelas estratégias de crescimento das empresas processadoras de alimentos. Além de ocupar uma posição estratégica dentro da cadeia, a indústria alimentar tem a dificil missão de decodificar os desejos e necessidades do consumidor, traduzindo-os em novas oportunidades de investimentos para si própria e transmitindo-os para seus fornecedores mais distantes, que pouco percebem o consumidor final".

Dentro do complexo tritícola, são as indústrias processadoras (indústrias de pães, massas, biscoitos, bolachas, cadeias de 'fast foods", etc.), as responsáveis por decodificar esta possibilidade de diferenciação, transmitindo-a para as indústrias de moagem através da exigência da oferta de farinhas específicas para a produção de produtos específicos.

Atualmente, já se percebe a procura, por parte das indústrias de derivados, dessas farinhas diferenciadas. A empresa de panificação Pullman, recentemente absorvida pelo moinho Plus Vita do grupo Bunge Brasil, por exemplo, tem oferecido vários tipos de pães diferenciados associados a sua marca.

Os moinhos têm investido, nos últimos anos, em processos que possibilitem esta diferenciação de farinhas, mesmo porque, se assim não o fizerem, poderão sofrer perdas significativas de mercado, devido à concorrência interna e das importações. Em 1993, Farina (1993 p. 4), já chamava a atenção para este problema: 
"A inexistência de oferta nacional de diferentes tipos de farinha, especialmente a de "grano duro" levou os pastificios mais agressivos a recorrer à importação, A opção da CICA foi importar a massa já elaborada da Itália, embora produzida sob sua orientação. A ADRIA importa o trigo "durum" do Canadá, processa a farinha na Argentina e a massa é industrializada no Brasil. A integração vertical, por sua vez, foi a opção encontrada pelos pastificios Dias Branco no Nordeste".

A diferenciação de produtos deve se tornar uma estratégia de crescimento importante para as empresas moageiras no Brasil, principalmente num ambiente de economia estabilizada e com perspectiva de crescimento da renda. A conquista de "hichos" específicos de mercado, com a oferta de produtos que atendam a determinadas exigências do consumidor, e a determinadas classes sociais, se tornam fundamentais para a própria sobrevivência dos moinhos.

\subsubsection{Estratégias de aquisição de matéria-prima}

Após a desregulação do mercado a indústria vem sendo abastecida predominantemente com o cereal importado $^{15}$. Esta situação representa um ganho substancial para os grandes moinhos situados próximos aos portos marítimos, através da redução dos custos de movimentação do cereal. Além disto, estes moinhos têm a vantagem de serem abastecidos com o produto mais barato e de melhor qualidade que o nacional.

Farina e Zylbersztajn (1992), destacam que, quando o processo industrial exige certas características específicas do produto agropecuário, pode-se afirmar que existe especificidade do ativo mantido pela indústria. $\mathrm{O}$ equipamento industrial é destinado a produzir determinado conjunto de produtos e depende de matérias-primas com especificações corretas. No caso do trigo, é pequena a capacidade industrial de modificar a matéria-prima a

\footnotetext{
${ }^{15}$ No ano safra $94 / 95$, por exemplo, a indústria consumiu $81 \%$ de cereal importado (ver Tabela 4.10 )
} 
fim de atender às exigências do mercado consumidor no que se refere aos "blends". O trigo de cada país é que tem características próprias que devem ser preservadas para a fabricação dos "blends" adequados à exigência dos clientes. Neste sentido, é importante que as empresas contem com um sistema de armazenagem adequado, que possibilite o acondicionamento correto, capaz de aproveitar as vantagens da diferenciação. Nesta pesquisa comprova-se que os grandes moinhos têm investido neste aspecto.

Outro fator relevante, no que se refere ao abastecimento de matéria-prima, é a vinculação do moinho a algum grupo econômico. Evidentemente, a compra do cereal em lotes maiores, feita pelos grandes conglomerados, oferece vantagens de preço e prazo para o importador. Além disto há, evidentemente, alguns grupos econômicos que têm vinculação empresarial com estes exportadores, o que aumenta suas vantagens na comercialização.

$\mathrm{O}$ abastecimento de matéria-prima afeta mais seriamente aos pequenos moinhos, que situam-se próximos às regiões produtoras, pois devido à desarticulação da produção nacional, só podem adquirir o cereal importado através de aquisições consorciadas, via "trandings", ou aceitando o repasse de grandes moinhos. Mesmo no caso da aquisição do produto nacional, é necessário que estes moinhos tenham estratégias bem definidas para garantirem o abastecimento, haja visto que somente as cooperativas teriam condições de absorver quase toda a pequena produção doméstica.

Para garantir o abastecimento adequado, as firmas podem recorrer à integração vertical $^{16}$ ou aos contratos de fornecimentos formais ou informais. Cabe aqui destacar que, os contratos firmados entre uma empresa e seus fornecedores ou distribuidores não se confundem com a integração vertical.

Segundo Farina e Zylbersztajn (1992, p. 83), a função dos contratos é minimizar os custos de produção e transação, de forma tão eficiente quanto a integração das atividades

\footnotetext{
${ }^{16} \mathrm{O}$ conceito de integração vertical aqui utilizado é o de Williamson (1985), que implica no controle hierárquico gerencial de estágios sucessivos de produção, tecnicamente separáveis.
} 
produtivas. Para os autores, a integração vertical e os contratos são formas organizacionais eficientes na presença de incertezas, especificidade de ativos produtivos e elevada freqüência das transações. Caso contrário, o mercado é a instituição mais eficiente. A escolha entre comprar ou fazer dependerá dos custos de produção (escala e escopo) e dos custos de transação. Se os custos de transação via mercado superam os custos do controle através da hierarquia, as atividades serão incorporadas pela firma. Caso contrário, é o mercado que será utilizado.

Para garantia do abastecimento e para aproveitamento de preços favoráveis, muitos moinhos já estão fazendo contratos antecipados de compra, tanto no exterior quanto no Brasil.

\subsection{O DESEMPENHO DA INDÚSTRIA DE MOAGEM ${ }^{17}$}

Farina (1993), afirma que ao final da intensa regulação por parte do governo, o setor de moagem encontrava-se com elevada concentração, excesso de capacidade produtiva e grande capacidade financeira decorrente do lucro elevado e garantido à época do controle do estado. Porém, a indústria, no geral, não se modemizara durante este período e muitas das empresas do setor iniciaram esta nova fase em condições desfavoráveis frente à concorrência que se anunciava. De fato, com o mercado liberado, verificam-se duas situações opostas:

1) por um lado os grandes moinhos, principalmente aqueles ligados a grandes gnupos econômicos, que além das vantagens de custos na produção em larga escala e das melhores condições financeiras ficam, por duas importantes razões, em situação privilegiada quando do acesso a matéria-prima importada. Em primeiro lugar, pelo fato de que estas grandes unidades localizam-se, em sua grande maioria, próximos aos portos marítimos o que

\footnotetext{
${ }^{17}$ Análise feita a partir dos dados dos balanços anuais dos moinhos, publicados na revista "Balanço Anual" da Gazeta Mercantil, para os anos de 1989 a 1996.
} 
reduziria os custos de transporte deste cereal que, além de poder ser adquirido, normalmente, a preços inferiores ao trigo nacional, têm a vantagem da qualidade, fundamental em uma estratégia de diferenciação de produto; em segundo lugar, pelas melhores condições de negociação junto aos grandes importadores, principalmente quando o moinho é ligado a algum conglomerado, quando então estas vantagens comerciais de prazo e condições de pagamento aumentariam, devido ao grande volume transacionado.

2) por outro lado, os pequenos e médios moinhos, com $100 \%$ de sua produção voltada para o mercado interno, ressentem-se de problemas quando da aquisição do cereal nacional, dadas as desvantagens de preços, qualidade e quantidade, ou quando da aquisição do importado, onde, neste segundo, caso estão enfrentando a concorrência das grandes empresas, com todas as suas vantagens. Além disto, na hora da venda da produção, se deparam com a concorrência, em termos de preço e qualidade, das grandes unidades e dos produtos importados.

$\mathrm{Na}$ análise do setor de moagem feito pela revista "Balanço Anual" da Gazeta Mercantil, de 1979 a 1989, este nunca apresentou prejuízo no seu conjunto ${ }^{18}$, sendo que em 1990, último ano de intervenção do governo, o setor apresentou um dos melhores desempenhos da indústria de alimentos em termos de faturamento e lucro líquido, garantidos pela segura margem de rentabilidade e pouca necessidade de capital de giro, que eram garantidos pelo sistema de controle estatal.

Com o fim do controle oficial na cadeia do trigo em 1990, os moinhos e as indústrias de derivados, tiveram de se adaptar rapidamente às novas regras e, principalmente, à exposição do setor ao mercado externo, o que acarretou custos mais elevados. Além disto,

\footnotetext{
${ }^{18}$ A revista Balanço Anual, da Gazeta Mercantil, faz uma análise do desempenho de algumas empresas do setor moinhos. Constam da análise as empresas sociedades anônimas que por lei são obrigadas a divulgar seus balanços e algumas limitadas, que embora não obrigadas a fazê-lo, divulgaram-no à revista. O número de moinhos analisados varia de ano a ano, porém nunca é inferior a 40 empresas. Em 1990 foram analisadas 51 empresas.
} 
enfrentaram a retração do mercado interno em 1990, o que ocasionou queda nas vendas e no faturamento ${ }^{19}$.

Apesar disto, alguns setores do Complexo Agroindustrial retomam os seus investimentos para enfrentar os novos tempos. Segundo dados da Associação Brasileira das Indústrias de Massas (ABIMA), o setor investiu entre 50 e 60 milhões de dólares, no biênio 1991/92, para modemização do parque industrial, desenvolvimento de tecnologia e aprimoramento da mão-de-obra. Em 1992, as empresas do setor de moagem aumentaram o seu nível de endividamento e a maioria delas fechou o ano com prejuízos (exceção feita a alguns moinhos do conglomerado Santista Alimentos).

A introdução do Plano Real, em 1994, provocou importantes mudanças nas relações e estratégias das empresas do ramo de alimentos e, em particular, as da moagem de trigo e de transformação de derivados. A maior estabilidade econômica, fez com que houvesse uma retomada da atividade e uma elevação da produção fisica, que não representaram, no entanto, aumento do faturamento do setor, em função da maior exposição à concorrência externa e à consolidação do Mercado Comum do Sul (MERCOSUL), que gerou uma redução dos preços dos produtos alimentícios. Por outro lado, a manutenção do poder aquisitivo das classes de renda mais baixa em função desta maior estabilidade da economia, aumentou o acesso aos produtos de maior elasticidade renda, como os das redes de fast food, biscoitos e massas finas.

Se o processo de abertura da economia, refletiu-se num aumento substancial das importações, também fez com que as exportações passassem a ser uma alternativa, como escoadouro da produção das empresas. Pelas Tabelas 4.12 e 4.13, verifica-se as importações e exportações de derivados de trigo de 1990 a 1995. Apesar dos produtos importados derivados de trigo terem, efetivamente, entrado em grande quantidade no país após 1990, o crescimento das vendas para o mercado externo também foi crescente no período.

\footnotetext{
${ }^{19} \mathrm{~A}$ saída do estado do setor, representou uma queda nas vendas dos moinhos analisados pela revista Balanço Anual de 16,1\%, em média, no ano de 1991.
} 
TABELA 4.12 Importação de produtos derivados do trigo, Brasil - 1990 e 1993 a 1995 (toneladas)

\begin{tabular}{lcccc}
\hline \hline Derivados do trigo & 1990 & 1993 & 1994 & $1995^{*}$ \\
\hline Farinha de trigo & 6,33 & $39.239,5$ & $141.174,0$ & $65.966,8$ \\
Bolachas e biscoitos amanteigados & & 197,4 & 454,5 & 713,4 \\
Bolachas e biscoitos de água e sal & & 289,6 & $1.119,1$ & 246,1 \\
Bolachas e biscoitos com maizena & & 7,2 & 17,5 & 6,0 \\
Bolachas e biscoitos com polvilho & & & & 0,9 \\
Bolachas e biscoitos sanduíche & 28,6 & $3.572,5$ & $3.224,5$ & $2.426,8$ \\
Massas alimentícias cozidas & 99,8 & & & \\
Amido de trigo & 185,6 & & & \\
Glúten de trigo & 4,0 & & & \\
Sêmola de trigo & 324,30 & $36.535,80$ & $146.225,30$ & $69.571,4$ \\
\hline Total de derivados importados
\end{tabular}

Fonte: SECEX/DECEX - SERPRO/SISTEMA ALICE (1996)

* Dados preliminares de janeiro a maio

TABELA 4.13 Exportação de trigo em grãos e produtos derivados de trigo, Brasil 1992 a 1996 (toneladas).

\begin{tabular}{|c|c|c|c|c|c|}
\hline Especificação & 1992 & 1993 & 1994 & 1995 & $1996^{*}$ \\
\hline Grão de trigo descascado & 11,0 & 15,0 & & 0,6 & 1 \\
\hline \multicolumn{6}{|l|}{ Trigo mourisco } \\
\hline Sêmola de trigo & & & & & \\
\hline Farinha de trigo & 18,0 & 58,6 & 79,6 & $2.173,2$ & $3.622,73$ \\
\hline Bolachas e biscoitos amanteig. & & & 251,6 & 351,1 & 356,7 \\
\hline Bolachas e biscoitos de água e sal & & & 125,3 & 200,8 & 182,9 \\
\hline Bolachas e biscoitos com maizena & & & 342,7 & 799,2 & 657,9 \\
\hline Bolachas e biscoitos com polvilho & & & & 6,2 & 0,3 \\
\hline Bolachas e biscoitos sanduíches & & & $3.547,4$ & $3.551,5$ & $3.547,4$ \\
\hline Massas alimentícias Recheadas & 3,9 & 13,4 & 1,4 & 7,4 & 19,6 \\
\hline Outras massa alimentícias cozidas & 62,4 & 108,4 & 27,2 & 37,5 & 61,6 \\
\hline Total & 95,30 & 195,40 & $4.375,20$ & $7.127,50$ & $8.450,13$ \\
\hline
\end{tabular}

Fonte: SECEX/DECEX - SERPRO/SISTEMA ALICE (1996)

*Dados preliminares de janeiro a setembro 
Os preços médios de exportação de farinha de trigo (Tabela 4.14), foram superiores aos preços de venda nos mercados atacadistas de São Paulo e do Paraná (Tabela 4.15 e 4.16), o que pode ter impulsionado as vendas para o exterior. Por outro lado, os preços de importação deste derivado (Tabela 4.14), foram inferiores aos preços domésticos, acirrando a concorrência interna.

TABELA 4.14 Farinha de trigo: preço médio de importação e exportação, 1992 a 1996 (US\$/k-FOB).

\begin{tabular}{ccc}
\hline \hline Ano & $\begin{array}{c}\text { Preço médio de exportação } \\
\text { (US\$/k) FOB }\end{array}$ & $\begin{array}{c}\text { Preço médio de } \\
\text { importação } \\
\text { (US\$/k) FOB }\end{array}$ \\
\hline 1992 & 1,89 & 0,21 \\
1993 & 0,32 & 0,20 \\
1994 & 0,43 & 0,20 \\
1995 & 0,54 & 0,22 \\
\hline
\end{tabular}

Fonte: SECEX/DECEX - SERPRO/SISTEMA ALICE (1996)

TABELA 4.15 Preço de venda da farinha de trigo comum no Estado do Paraná, varejo e atacado, 1991 a 1996 (US\$/k*).

\begin{tabular}{ccc}
\hline \hline Ano & $\begin{array}{c}\text { Preço Atacado } \\
\text { (média anual) }\end{array}$ & $\begin{array}{c}\text { Preço no varejo } \\
\text { (média anual) }\end{array}$ \\
\hline 1991 & 0,26 & 0,37 \\
1992 & 0,28 & 0,37 \\
1993 & 0,27 & 0,37 \\
1994 & 0,30 & 0,36 \\
1995 & 0,31 & 0,41 \\
$1996^{* *}$ & 0,43 & 0,56 \\
\hline \hline
\end{tabular}

Fonte: SEAB/DERAL/ PR * Dólar comercial de compra do dia 15 de cada mês.

** Dados preliminares de janeiro a setembro. 
TABELA 4.16 Preço de venda da farinha de trigo especial no estado do Paraná, varejo e atacado, 1991 a 1996 (US\$/k).

\begin{tabular}{ccc}
\hline \hline Ano & $\begin{array}{c}\text { Preço no atacado } \\
\text { (média anual) }\end{array}$ & $\begin{array}{c}\text { Preço no varejo } \\
\text { (média anual) }\end{array}$ \\
\hline 1991 & 0,35 & 0,48 \\
1992 & 0,36 & 0,49 \\
1993 & 0,35 & 0,46 \\
1994 & 0,37 & 0,49 \\
1995 & 0,40 & 0,56 \\
$1996^{*}$ & 0,55 & 0,76 \\
\hline \hline
\end{tabular}

Fonte: SEAB/DERAL/PR * Dados preliminares de janeiro a setembro

Tendo em vista o setor ter ficado muito dependente do mercado externo para a aquisição de matéria-prima, é sujeito às variações ocasionais de oferta e preços, fato ocorrido ocasionalmente em 1995 e 1996, com a elevação dos preços no mercado internacional e conseqüente pressão sobre os custos em toda a cadeia e elevação de preços da farinha e derivados no mercado interno (Tabelas 4.15, 4.16 e 4.17).

TABELA 4.17 Preços no mercado varejista de São Paulo de produtos derivados de trigo e preço do farelo de trigo, 1991 a 1995 (média anual em US\$)*

\begin{tabular}{cccccc}
\hline \hline Ano & $\begin{array}{c}\text { Macarrão } \\
(\text { Pct de } 500 \mathrm{~g})\end{array}$ & $\begin{array}{c}\text { Pão Francês } \\
(50 \mathrm{~g})\end{array}$ & $\begin{array}{c}\text { Pão Bengala } \\
(300 \mathrm{~g})\end{array}$ & $\begin{array}{c}\text { Far. de Trigo } \\
(\mathrm{k})\end{array}$ & $\begin{array}{c}\text { Farelinho de Trigo } \\
(\mathrm{k})\end{array}$ \\
\hline 1991 & $\mathbf{0} 65$ & 0,05 & 0,28 & 0,50 & 0,11 \\
1992 & 0,66 & 0,06 & 0,34 & 0,62 & 0,10 \\
1993 & 0,55 & 0,06 & 0,36 & 0,52 & 0,10 \\
1994 & 0,66 & 0,06 & 0,37 & 0,55 & 0,12 \\
1995 & 0,72 & 0,07 & 0,46 & 0,62 & 0,14 \\
\hline
\end{tabular}

Fonte: IEA/SP (1996). *Dólar comercial.




\subsection{ANÁLISE INTERPRETATIVA DA PESQUISA REALIZADA JUNTO ÀS EMPRESAS MOAGEIRAS BRASILEIRAS}

\subsubsection{Considerações iniciais}

A fim de verificar alguns aspectos importantes da estrutura, conduta e desempenho das empresas moageiras no Brasil, tais como: suas vantagens locacionais; o aproveitamento da capacidade instalada; os investimentos em modernização do setor de moagem e na qualificação da mão de obra; as estratégias de aquisição de matéria-prima, a abrangência do mercado consumidor e as táticas comerciais das firmas na indústria, foi aplicado um questionário com perguntas abertas e fechadas (vide anexo 1). Parte-se do pressuposto de que algumas conclusões a respeito da amostra observada podem ser generalizadas para o universo das empresas moageiras.

Esta análise não seguiu sistematicamente a seqüência das questões formuladas, que foram, muitas vezes, agrupadas no sentido de se ter uma melhor compreensão dos aspectos mencionados.

Para facilitar o estudo, os moinhos pesquisados foram divididos em quatro classes segundo suas capacidades de moagem em toneladas/24h. Isto foi necessário, tendo em vista algumas evidências de que o comportamento e as estratégias das empresas são diferenciadas em função de suas escalas de produção. A definição das classes de moagem a serem utilizadas, no entanto, tem muito de arbitrário, porém, alguns estudos fornecem alguns indicativos para uma melhor compreensão deste aspecto. Lockwood $(1951)^{20}$ citado em Soares (1980), por exemplo, ao calcular os custos da moagem de 1 tonelada de trigo, o faz para moinhos de $20 \mathrm{t} / 24 \mathrm{~h}, 62 \mathrm{t} / 24 \mathrm{~h}, 120 \mathrm{t} / 24 \mathrm{~h}, 200 \mathrm{t} / 24 \mathrm{~h}$ e $400 \mathrm{t} / 24 \mathrm{~h}$. Segundo o autor, os custos totais de produção por tonelada de trigo reduzem-se à 
medida que aumenta a capacidade de moagem, ou seja, há economias de escala na indústria de moagem. Segundo seus cálculos, o custo da moagem de 1 tonelada de trigo para um moinho com capacidade de $400 \mathrm{t} / 24 \mathrm{~h}$ é equivalente a $60 \%$ do custo de um moinho com capacidade de $20 \mathrm{t} / 24 \mathrm{~h}$; no entanto, moinhos com capacidade de moagem de $200 \mathrm{t} / 24 \mathrm{~h}$ e $400 \mathrm{t} / 24 \mathrm{~h}$ apresentaram valores muito aproximados dos custos por tonelada produzida. Silva (1989), classifica pequenos moinhos como as unidades com capacidade de moagem de até $100 \mathrm{t} / 24 \mathrm{~h}$ e considera que a eficiência técnica na produção seria obtida pelos moinhos com capacidade compreendida entre 200 e $400 \mathrm{t} / 24 \mathrm{~h}$, o que vem de encontro às conclusões de Lockwood (1951). Mendes et al. (1994), em seu estudo, divide os moinhos em 3 classes: até $110 \mathrm{t} / 24 \mathrm{~h}$, de 110 a $500 \mathrm{t} / 24 \mathrm{~h}$ e de 500 a $1200 \mathrm{t} / 24 \mathrm{~h}$.

Diante destas observações e de informações colhidas junto a representantes da indústria moageira, optou-se por considerar a seguinte classificação dos moinhos por classe de moagem:

Classe I: Moinhos de até $50 \mathrm{t} / 24 \mathrm{~h}$ (muito pequenos)

Classe II: Moinhos de 60 a $150 \mathrm{t} / 24 \mathrm{~h}$.(moinhos pequenos)

Classe III: Moinhos de 200 a 400 t/24h(moinhos tecnicamente eficientes)

Classe IV: Moinhos de 450 a 800 t/24h (grandes moinhos)

Classe V : Moinhos de 1400 a 2800 t/24h (muito grandes)

\subsubsection{Análise dos dados}

Dos 202 questionários enviados, 76 deles foram respondidos de forma completa (38\%), o que caracteriza uma amostra significativa do universo em análise. A Tabela 4.18 , mostra o número de moinhos pesquisados, por classe de moagem e o percentual em relação ao total de respostas. ${ }^{21}$

\footnotetext{
${ }^{21}$ No Anexo 2, consta a relação nominal dos moinhos que responderam a pesquisa.
} 
TABELA 4.18 Número de moinhos pesquisados por classes de moagem e percentual em relação ao total, 1996.

\begin{tabular}{cccc}
\hline $\begin{array}{c}\text { Classe de } \\
\text { capacidade }\end{array}$ & $\begin{array}{c}\text { Capacidade em } \\
\text { toneladas/24h }\end{array}$ & $\begin{array}{c}\text { Quantidade de moinhos } \\
\text { pesguisados }\end{array}$ & $\begin{array}{c}\text { Percentual de respostas em } \\
\text { relação ao total }\end{array}$ \\
\hline I & até 50 & 37 & 48,68 \\
II & 60 a 150 & 13 & 17,11 \\
III & 200 a 400 & 15 & 19,74 \\
IV & 450 a 800 & 07 & 9,21 \\
V & 1400 a 2800 & 04 & 5,26 \\
\hline Total & & 76 & 100 \\
\hline \hline
\end{tabular}

Fonte: Dados de pesquisa (1996)

Dos 76 moinhos pesquisados, dois situam-se na região Norte do Brasil (um da classe III e outro da IV); três na Nordeste (um da classe III e outro da IV); três na Centro-Oeste (Classe III e IV); nove na Sudeste (III, IV, V); e cinqüenta e nove na Sul (I, II, III). Doze do total destes moinhos são pertencentes a grupos ou conglomerados econômicos do setor agroindustrial e quinze ligados a cooperativas agrícolas.

Outras observações importantes foram: dois moinhos da classe III arrendados a um mesmo grande grupo econômico, sendo que um deles com suas atividades paralisadas no final do ano de 1996, e outro, com planos de montagem de uma nova unidade na região Sul; dois moinhos da classe I com suas atividades paralisadas, sendo um deles ligado a cooperativa agrícola.

Apenas 5 moinhos não operavam à época do mercado regulado. Destas unidades inauguradas pós-desregulação (1990), duas delas, das classes I e III, são ligadas a cooperativas agrícolas, duas da classe II situam-se na região produtora do Oeste do Paraná e uma da classe IV é ligada a um conglomerado alimentício. 
4.3.2.1 Vantagens locacionais.

A Tabela 4.19, apresenta os resultados quanto ao número de unidades moageiras próximas às regiões produtoras ${ }^{22}$. Estas são, predominantemente, de pequeno porte, situados ou na região Sul ou Centro-Oeste. $73 \%$ dos moinhos pesquisados da classe I e $85 \%$ da classe II encontram-se nesta localização.

TABELA 4.19 Número de moinhos próximos a regiões produtoras, 1996.

\begin{tabular}{lcccl}
\hline \hline Classe & $\begin{array}{c}\mathrm{N}^{\circ} \text { de } \\
\text { moinhos }\end{array}$ & $\begin{array}{c}\mathrm{N}^{\circ} \text { de moinhos próximos } \\
\text { a regiões produtoras }\end{array}$ & $\begin{array}{c}\text { Percentual em relação ao } \\
\text { total da classe }\end{array}$ & Localização Regional \\
\hline I & 37 & 27 & 73 & Região Sul \\
II & 13 & 11 & 85 & Região Sul \\
III & 15 & 05 & 33 & 4 da Região Sul, 1 da \\
& & & & Centro-Oeste \\
IV & 07 & 01 & 14 & Região Centro-Oeste \\
V & 04 & 00 & 00 & - \\
\hline
\end{tabular}

Fonte: Dados da pesquisa (1996)

A tabela 4.20 mostra o número de moinhos próximos a grandes centros consumidores $^{23}$. Quase todos os moinhos das classes III, IV e V situam-se próximos às regiões consumidoras dos grandes centros urbanos, sendo $80 \%$ dos moinhos das classe III, e $100 \%$ dos moinhos das classes IV e V.

${ }^{22}$ Considerou-se, na pesquisa, moinhos que estejam localizados até $100 \mathrm{~km}$ de região produtora de trigo.

${ }^{23}$ Considerou-se, na pesquisa, moinhos próximos a cidades com 300 mil habitantes, ou mais. 
TABELA 4.20 Número de moinhos próximos a grande centros consumidores, 1996

\begin{tabular}{lcccl}
\hline \hline Classe & $\begin{array}{c}\mathrm{N}^{\circ} \text { total de } \\
\text { moinhos }\end{array}$ & $\begin{array}{c}\mathrm{N}^{\circ} \text { de moinhos próximos } \\
\text { a grande centro } \\
\text { consumidor }\end{array}$ & $\begin{array}{c}\text { \% em relação ao } \\
\text { total de classe }\end{array}$ & \multicolumn{1}{c}{ Localizaç̃o regional } \\
\hline I & 37 & 12 & 33 & Região Sul \\
II & 13 & 04 & 31 & Região Sul \\
III & 15 & $12^{*}$ & 80 & Região Sul, SE, NE, CO \\
IV & 07 & 07 & 100 & Região CO, NE, SE, Norte \\
V & 04 & 04 & 100 & Região Sudeste \\
\hline
\end{tabular}

Fonte: Dados da pesquisa (1996)

Obs. ${ }^{*}$ Cinco deles ligados a grupos econômicos

Pela Tabela 4.21 verifica-se que 4 moinhos das classes I e II, mesmo estando localizados próximos aos portos marítimos, importam relativamente pouco cereal $(\mathrm{e}$, preferencialmente esta importação é da Argentina) Já os moinhos das classes III, IV e V apresentam, no geral, percentuais maiores de utilização de trigo importado, aumentando estes percentuais quando aumenta a classe. Os moinhos ligados a grupos econômicos são os que têm o maior percentual de utilização do produto externo. A pauta de países vendedores é, também, diversificada nas classes III, IV, e V. Isto sugere que a utilização de trigo importado tem pouca relação com a proximidade portuária e maior relação com o tamanho do moinho e sua ligação a algum grupo econômico financeiro. 
TABELA 4.21 Moinhos próximos a portos marítimos e percentual de utilização de trigo importado, 1996

\begin{tabular}{lccccc}
\hline \hline Classe & $\begin{array}{c}\mathrm{N}^{\circ} \text { total } \\
\text { de } \\
\text { moinhos }\end{array}$ & $\begin{array}{c}\mathrm{N}^{\circ} \text { de moinhos } \\
\text { próximos aos } \\
\text { portos }\end{array}$ & $\begin{array}{c}\text { Percentual em relaçã ao } \\
\text { total da classe }\end{array}$ & $\begin{array}{c}\text { Percentual de } \\
\text { utilização de trigo } \\
\text { importado }\end{array}$ & $\begin{array}{c}\text { origem do cereal } \\
\text { importado }\end{array}$ \\
\hline I & 37 & 03 & 8,11 & $20,30,50$ & Argentina \\
II & 13 & 01 & 7,69 & 10 & Argentina \\
III & 15 & 08 & 53 & $30,60,80^{1}, 100^{2}$ & Variada \\
IV & 07 & 04 & 57 & $60 \mathrm{e} 100^{3}$ & Variada \\
V & 04 & 04 & 100 & $70,80^{4}, 90$ & Variada \\
\hline \hline
\end{tabular}

Fonte: Dados da pesquisa (1996).

Obs 1: Dois moinhos ligados a grupos econômicos

2: Quatro moinhos, sendo três deles ligados a grupos econômicos

3: Três moinhos

4: Dois moinhos

4.3.2.2 Grau de utilização, ampliações e projetos de ampliação da capacidade

$\mathrm{Na}$ Tabela 4.22 tem-se a capacidade de moagem instalada, a efetiva (real) e o nível de ociosidade dos moinhos, por classe de moagem, além da participação percentual de cada moinho na capacidade total (relação entre capacidade instalada do moinho e capacidade total de todos os moinhos pesquisados).

Em relação à participação percentual de cada moinho sobre a capacidade total, verifica-se que os 50 moinhos das classes I e II têm uma capacidade de oferta residual em relação ao total $(11,71 \%$ ), enquanto os médios e grandes detêm $88,29 \%$ de toda a capacidade. Os moinhos da classe V (moinhos com capacidade superior a 1400 toneladas) destacam-se com $43,45 \%$ de toda a capacidade de moagem levantada na pesquisa. Em relação ao grau de ociosidade dos moinhos verifica-se que os moinhos com 
maior capacidade ociosa são os de classe I, enquanto os que operam com melhor aproveitamento do seu potencial de moagem são os moinhos de classe III.

TABELA 4.22 Capacidade de moagem instalada real, percentual de cada moinho sobre a capacidade total e nível de capacidade ociosa dos moinhos pesquisados, por classe de moagem (1996)

\begin{tabular}{lccccc}
\hline Classes & $\mathrm{N}^{\circ}$ de moinhos & $\begin{array}{c}\text { Cap. instalada } \\
(\mathrm{t} / 24 \mathrm{~h})\end{array}$ & $\begin{array}{c}\text { Participação (\%) } \\
\text { na capacidade } \\
\text { total }\end{array}$ & $\begin{array}{c}\text { Cap. real } \\
(\mathrm{t} / 24 \mathrm{~h})\end{array}$ & Ociosidade \% \\
\hline I & 37 & 1.015 & 5,65 & 673 & 34 \\
II & 13 & 1.087 & 6,06 & 862 & 21 \\
III & 15 & 4.290 & 23,90 & 3.640 & 15 \\
IV & 07 & 3.760 & 20,94 & 2.790 & 26 \\
V & 04 & 7.800 & 43,45 & 5.500 & 29 \\
\hline Total & 76 & 17.952 & 100 & 13.465 & $25 \%$ \\
\hline \hline
\end{tabular}

Fonte: Dados da pesquisa (1996)

Quanto às expansões realizadas nos últimos 6 anos e os projetos de expansão dos moinhos pesquisados, por classe de moagem, observam-se os resultados na Tabela 4.23. Em relação à classe $I$, doze moinhos já realizaram expansões e treze têm projetos de ampliação. Provavelmente, estes moinhos, que eram muito menores à época do mercado regulado, assim o fizeram na expectativa de um aumento de suas vendas e redução de seus custos unitários. O que se observa, no entanto, é que provavelmente, estas expansões tenham ocasionado um aumento do nível da capacidade ociosa das empresas (esta é a classe que apresenta o maior percentual, com $34 \%$ ), o que reflete as dificuldades de se manter no mercado operando nesta escala. 
TABELA 4.23 Ampliação realizadas de 1990 a 1996 e projetos de ampliações a curto e médio prazos dos moinhos.

\begin{tabular}{lcccccccc}
\hline \hline Classes & $\begin{array}{c}\mathrm{N}^{\circ} \text { de } \\
\text { moinhos }\end{array}$ & $\begin{array}{c}\mathrm{N}^{\circ} \text { de moinhos } \\
\text { que realizaram } \\
\text { ou realizarão } \\
\text { expansão }\end{array}$ & $\begin{array}{c}\text { Capacidade } \\
\text { instalada } \\
(\mathrm{t} / 24 \mathrm{~h})\end{array}$ & $\begin{array}{c}\text { ampliações } \\
\text { de } \\
\text { capacidade } \\
(\mathrm{t} / 24 \mathrm{~h})\end{array}$ & $\begin{array}{c}\text { Crescimento } \\
\text { no periodo } \\
(\%)\end{array}$ & $\begin{array}{c}\text { Total dos } \\
\text { projetos de } \\
\text { ampliação } \\
(\mathrm{t} / 24 \mathrm{~h})\end{array}$ & $\begin{array}{c}\text { Projeção da nova } \\
\text { capacidade em } \\
\text { função do } \\
\text { aumento. }(\mathrm{t} / 24 \mathrm{~h})\end{array}$ & $\begin{array}{c}\text { Crescim. } \\
\text { esperado } \\
(\%)\end{array}$ \\
\hline I & 37 & 25 & 1.015 & 175 & 20,83 & 496 & 1.511 & 48,87 \\
II & 13 & 14 & 1.087 & 507 & 87,41 & 851 & 1.938 & 78,29 \\
III & 15 & 16 & 4.290 & 1.003 & 30,51 & 1.050 & 5.340 & 24,48 \\
IV & 07 & 10 & 3.760 & 1.416 & 60,41 & 625 & 4.385 & 16,62 \\
V & 04 & 03 & 7.800 & 380 & 5,12 & 1.400 & 9.200 & 17,95 \\
\hline Total & 76 & 68 & 17.952 & 3.481 & 24,06 & 4.422 & 22.374 & 24,63 \\
\hline
\end{tabular}

Fonte: Dados da pesquisa (1996)

Obs.: A diferença entre o número de moinhos que realizaram ou realizarão expansão é devido ao fato que algumas unidades expandiram-se e ainda têm projetos de expansão.

Alguns moinhos com capacidade de $50 \mathrm{t} / 24 \mathrm{~h}$ (classe I), declararam ter projetos de expansão para operar com uma capacidade aproximada de $100 \mathrm{t} / 24 \mathrm{~h}$, inclusive já tendo adquirido máquinas para tal. No entanto, em função de uma falta de expectativa em relação a um melhor posicionamento no mercado, não colocaram ainda seus novos equipamentos em operação. Além disto, ressalte-se que, nesta classe, dois moinhos já encontram-se com suas atividade totalmente paralisadas.

Várias declarações coletadas na pesquisa revelam as grandes dificuldades de operação na pequena escala das classe I, desde as relacionadas aos custos elevados de operação (e, conseqüentemente, falta de competitividade com os grandes, em relação a preços), até as de concorrer com os produtos argentinos que, têm vantagem de preço e prazo na comercialização, além de tarifas de importação preferenciais em relação ao MERCOSUL. Nas palavras de um proprietário de pequeno moinho no sul do país: 
"Para ampliar nossa produção foram importados da Alemanha 8 cilindros eletrônicos que, no entanto, acham-se embalados nos depósitos da firma. Não foram instalados face à baixa rentabilidade do setor decorrente das importações de biscoitos, massas, farinha de trigo e outros milagres que ocorrem na comercialização da farinha de trigo, possibilitando a certos conglomerados internacionais venderem $o$ produto abaixo do preço de custo".

A classe II (60 a $150 \mathrm{t} / 24 \mathrm{~h})$ é a que mais ampliou e a que tem maior expectativa de crescimento $(78,29 \%)$. Isto sugere que algumas unidades crescem na expectativa de alcançar o tamanho ótimo da planta e operar em uma escala mais eficiente em termos de aproveitamento de todas as economias (a tese é que moinhos com capacidade compreendida entre 200 e $400 \mathrm{t} / 24 \mathrm{~h}$ seriam os de tamanho mais eficientes). Vale lembrar também que na classe III (200 a 400 t/24h) registram-se os menores níveis de capacidade ociosa (15\%). Enfim, constata-se que os moinhos da classe $\mathrm{V}$ foram os que menos cresceram após a desregulação do mercado (1990), haja visto já operarem em uma grande escala nesta época.

No geral, verifica-se que a maioria dos moinhos pesquisados ampliaram ou têm projetos de ampliação da capacidade de moagem. No total do universo da pesquisa houve um crescimento de $24,06 \%$ de 1990 para 1996. Além disto, há projetos de ampliação que elevariam a capacidade de moagem total em mais $24,63 \%$, a médio e longo prazos.

\subsubsection{Capacidade de estocagem.}

A Tabela 4.24, resume os resultados apurados quanto à capacidade de estocagem de trigo em grão dos moinhos em toneladas e à capacidade de estocagem de farinha de trigo. Para fins de análise registram-se, também, nesta tabela os dados referentes a capacidade de moagem instalada. 
TABELA 4.24 Capacidade estática de estocagem de trigo em grão, de farinha de trigo e capacidade de moagem instalada, 1996.

\begin{tabular}{lcccc}
\hline \hline Classes & $\mathrm{N}^{\circ}$ de moinhos & $\begin{array}{c}\text { Capacidade de moagem } \\
\text { instalada }(\mathrm{V} / 24 \mathrm{~h})\end{array}$ & $\begin{array}{c}\text { Capacidade de estocagem } \\
\text { de trigo em grão }(\mathrm{t})\end{array}$ & $\begin{array}{c}\text { Capacidade de estocagem } \\
\text { de farinha de trigo }(\mathrm{t})\end{array}$ \\
\hline $\mathrm{I}$ & 37 & 1.015 & 65.133 & 2.167 \\
II & 13 & 1.087 & 119.000 & 3.692 \\
III & 15 & 4.290 & 76.550 & 6.620 \\
IV & 07 & 3.760 & 116.800 & 8.350 \\
V & 04 & 7.800 & 190.000 & 39.200 \\
\hline Total & 76 & 17.952 & 448.602 & 60.039 \\
\hline \hline
\end{tabular}

Fonte: Dados da pesquisa (1996).

Segundo informações de representantes do setor de moagem, a estocagem de trigo em grão ideal é, normalmente, igual a 30 dias de moagem e a de farinha, igual a 1 semana. Desta forma, a capacidade de estocagem de trigo em grão do total dos moinhos pesquisados (448.602 t), estaria um pouco abaixo do ideal que seria de $538.560 \mathrm{t}$. Da mesma forma, a capacidade de estocagem de farinha (60.039 t), também está abaixo do nível recomendado, que deveria ser de $125.664 \mathrm{t}$.

$\mathrm{Na}$ análise por classes de moagem, é possível inferir que apenas na classe III, alguns moinhos não teriam a capacidade de estocagem de trigo ideal, e as demais apresentariam boas condições de estocagem do produto. Destaca-se, neste sentido, a opinião de alguns analistas do setor os quais afirmam que os grandes moinhos situados próximos aos portos marítimos, teriam vantagens em revender o cereal importado aos moinhos pequenos afastados dos portos e, por isso, teriam uma grande capacidade de armazenar o cereal. 
4.3.2.4 Número de funcionários e qualificação da mão-de-obra.

Com relação à mudança na estrutura organizacional nos últimos 6 anos, todos os moinhos das classes V e IV afirmaram tê-la realizada. Não a fizeram, dois moinhos na classe III, um na classe II e doze na classe I.

A Tabela 4.25 , resume os resultados da pesquisa no que se refere ao número de funcionários e aos investimentos em treinamento da mão-de-obra.

TABELA 4.25 Total de funcionários por classe de moagem, uso de mão-de-obra familiar e quantidade de moinhos que fizeram investimento em qualificação de mão de obra. (1990 a 1996)

\begin{tabular}{lccccc}
\hline \hline Classes & $\mathrm{N}^{\circ}$ de moinhos & \multicolumn{2}{c}{ Total de funcionários } & $\begin{array}{c}\mathrm{N}^{\circ} \text { moinhos que } \\
\text { utilizam mão- } \\
\text { de-obra familiar }\end{array}$ & $\begin{array}{c}\mathrm{N}^{\circ} \text { de moinhos que } \\
\text { investiram em } \\
\text { qualificação da M.O } \\
\text { (1990 a 1996) }\end{array}$ \\
\cline { 2 - 4 } & 37 & $\begin{array}{c}\text { Setor } \\
\text { operacional }\end{array}$ & $\begin{array}{c}\text { Setor } \\
\text { Administrativo. }\end{array}$ & & \\
\hline I & 422 & 84 & 20 & 21 \\
II & 13 & 1.303 & 68 & 07 & 09 \\
III & 15 & 1.148 & 721 & 03 & 12 \\
IV & 07 & 540 & 210 & 01 & 07 \\
V & 04 & 500 & 440 & 01 & 04 \\
\hline Total & 76 & 3.913 & 1.523 & 32 & 53 \\
\hline \hline
\end{tabular}

Fonte: Dados da pesquisa (1996)

O uso de mão-de-obra familiar é predominante na classe I e II (moinhos do Sul do País). Nas classes com maior capacidade de moagem, a mão-de-obra familiar só está presente em moinhos próximos às regiões produtoras. 
Percebem-se diferenças no número de funcionários empregados no setor operacional do moinho, entre unidades com praticamente a mesma capacidade de moagem, principalmente nas maiores classes. Citem-se, como exemplo, 2 moinhos com capacidade de moagem de $500 \mathrm{t} / 24 \mathrm{~h}$, um utilizando 43 funcionários no setor operacional e o outro 110. Investimentos na qualificação dos funcionários são crescentes à medida que aumenta o tamanho dos moinhos. $56 \%$ das empresas da classe I fizeram investimentos deste tipo, o mesmo ocorrendo com todos os moinhos das classes IV e V.

4.3.2.5 Investimentos em modernização, renovação ou ampliação do setor de moagem e de armazenagem do grão

A Tabela 4.26, permite a observação do número de moinhos que realizaram investimentos em modernização, renovação ou ampliação no setor de moagem e no setor de armazenagem de grãos. No geral, os moinhos de quase todas as classes realizaram estes investimentos, sendo que as únicas exceções foram os das unidades da classe I, onde apenas $50 \%$ o fizeram.

TABELA 4.26 Número de moinhos que investiram no setor de moagem e armazenagem de trigo, 1996.

\begin{tabular}{lccc}
\hline \hline Classes & $\mathrm{N}^{\circ}$ de moinhos & $\begin{array}{c}\mathrm{N}^{\circ} \text { de moinhos que investiram } \\
\text { no setor de moagem }\end{array}$ & $\begin{array}{c}\mathrm{N}^{\circ} \text { de moinhos quem } \\
\text { investiram no setor de } \\
\text { armazenagem }\end{array}$ \\
\hline I & 37 & 21 & 19 \\
II & 13 & 12 & 06 \\
III & 15 & 14 & 10 \\
IV & 07 & 07 & 06 \\
V & 04 & 04 & 03 \\
\hline Total & 76 & 58 & 34 \\
\hline
\end{tabular}

Fonte: Dados da pesquisa (1996) 
Em relação ao aspecto de modernização dos moinhos, pode-se analisar ainda, através da Tabela 4.27, o processo de descarregamento do trigo e a etapa de ensacamento e ensilagem de derivados, verificando-se se este processo é manual, parcialmente ou totalmente automatizado.

Observa-se que nas duas etapas do processo, o maior número de moinhos que operam em processo manual encontra-se nas classes I e II, vis a vis ao maior número de moinhos que operam com processo totalmente automatizado ou parcialmente automatizado, que se concentram nas classes IV e V.

TABELA 4.27 Processo de descarregamento do trigo em grão e etapa de ensacamento e ensilagem de derivados, 1996.

\begin{tabular}{lcccccc}
\hline \hline Classes & \multicolumn{3}{c}{ Etapa de descarregamento } & \multicolumn{2}{c}{ Etapa de ensacamento e ensilagem } \\
\cline { 2 - 6 } & MA & PA & TA & MA & PA & TA \\
\hline I & 12 & 20 & 05 & 15 & 17 & 05 \\
II & 03 & 09 & 01 & 03 & 09 & 01 \\
III & 01 & 09 & 04 & 01 & 10 & 03 \\
IV & 01 & 02 & 04 & - & 04 & 03 \\
V & - & 03 & 01 & - & 02 & 02 \\
\hline \hline
\end{tabular}

Fonte: Dados da pesquisa (1996)

Legendas: $\mathrm{MA}=$ Manual

PA = Parcialmente automatizada

$\mathrm{TA}=$ Totalmente automatizada 
4.3.2.6 Estratégias de aquisição de matéria-prima.

Quanto à utilização de trigo importado, verifica-se que: os moinhos de trigo da classe $\mathrm{V}$ utilizam, em média, $80 \%$ de cereal importado em relação ao total adquirido; os da classe IV, $85 \%$; os da classe III, $61 \%$; os da classe II, $35 \%$ e os da classe I, $30 \%$. Existem ainda, nas classes I, II e IV, sete, cinco, e um moinhos respectivamente, que não utilizam trigo importado. O responsável por um dos moinhos da classe IV, localizado próximo à região produtora, declarou que a partir deste ano a unidade começará a importar trigo da Argentina. Para tanto, está investindo em terminal ferroviário, dada a proximidade do moinho a esta via.

Pode-se concluir que o percentual de utilização de trigo importado aumenta acompanhando o aumento do tamanho do moinho, o que possibilita acreditar que exista uma relação direta entre estas duas variáveis, como já salientado.

Em relação ao fornecimento do cereal importado, a Argentina aparece como principal fornecedor, seguida do Canadá e dos EUA. É importado, ainda, em proporções menores, trigo do Paraguai, Uruguai, Alemanha e Turquia. Os moinhos pertencentes às classes I e II (do Sul do País) importam predominantemente o cereal argentino. Porém, os maiores moinhos, destacando-se os das classes IV e V, têm fornecedores variados.

Os principais fornecedores dos moinhos pesquisados são, produtores nacionais, cooperativas, corretores, importadores (via "Tradings" principalmente), Governo (através dos leilões da CONAB) e cerealistas.

As cooperativas agrícolas adquirem basicamente, o cereal de seus associados; o que não exclui a aquisição de outros fornecedores nem a de cereal importado. 
A ordem de importância dos fornecedores de trigo é muito variável para todos os moinhos em todas as classes. As empresas que predominantemente utilizam-se do cereal importado têm grandes vantagens na aquisição do cereal, em termos de qualidade e quantidade, tendo em vista o mercado externo do produto ser muito mais estável do que o interno, nestes dois aspectos.

Pelos dados da Tabela 4.28, verifica-se a quantidade de moinhos, por classe de moagem, que realizam contratos antecipados de compra de trigo em grão, a fim de ter garantido o suprimento desta matéria-prima. Pode-se observar que tal aspecto é uma preocupação geral, principalmente por parte dos grandes moinhos.

TABELA 4.28 Número de moinhos que realizam contratos antecipados de compra de trigo, 1996.

\begin{tabular}{lccccc}
\hline \hline \multirow{2}{*}{ Classes } & N $^{\circ}$ total de moinhos & \multicolumn{4}{c}{ Realizam contratos antecipados de compra com: } \\
\cline { 2 - 6 } & & Coop & PA & IMP & NR \\
\hline I & 37 & 04 & 09 & 05 & 20 \\
II & 13 & 03 & 01 & 04 & 07 \\
III & 15 & 04 & 01 & 09 & 03 \\
IV & 07 & 01 & 01 & 06 & 00 \\
V & 04 & 01 & 01 & 03 & 00 \\
\hline Total & 76 & 13 & 13 & 27 & 30 \\
\hline
\end{tabular}

Fonte: Dados da pesquisa (1996).

Legendas: Coop: Cooperativas

PA: Produtores agrícola

IMP: Importadores

NR: Não realizam contratos antecipados de compra de trigo 
As condições comerciais mais favoráveis, e principalmente a qualidade do grão e sua diversidade para preparação de farinhas diferenciadas, são aspectos importantes, que são levados em consideração por todos os moinhos quando da aquisição do cereal.

Todas as grandes empresas realizam algum tipo de análise da matéria-prima e do produto final, sendo que somente algumas poucas empresas das classes I, II e III não o fazem, evidenciando, mais uma vez, as preocupações com a qualidade. A maioria das empresas, em todas as classes, contam também com sistemas de informações sobre câmbio e oferta de trigo em grão, em vários mercados.

\subsubsection{Abrangência do mercado e estratégias comerciais}

A Tabela 4.29, mostra a abrangência do mercado dos moinhos pesquisados, por classes de moagem. Com raras exceções de algumas firmas que vendem seus produtos em todo o país, a grande maioria dos moinhos tem seus mercados restritos aos estados ou às regiões onde estão instalados, confirmando a hipóteses formulada por Silva (1989), que considera o mercado dos moinhos como regional devido aos altos custos de transportes, relativamente ao valor agregado.

Com exceção de alguns moinhos, ligados às cooperativas de produtores, que fornecem seus produtos aos cooperados ou transferem o farelo de trigo produzido para suas próprias fábricas de ração, a grande maioria das empresas pesquisadas, em todas as classes, tem sua clientela bastante diversificada, destacando-se: supermercados, padarias, indústrias de biscoitos e massas, indústria de rações e cooperativas. Moinhos de menor porte têm como compradores preferenciais o mercado varejista, supermercados e padarias. Já os moinhos da classe V diversificam ainda mais seus compradores, fornecendo também seus produtos a pizzarias, pastelarias, cadeias de "fast food" e 
atacadistas. Pelas respostas fornecidas percebe-se que, cada empresa, seja ela de porte pequeno, médio ou grande, procura atender segmentos bastante específicos do mercado.

TABELA 4.29 Abrangência do mercado dos moinhos, 1996.

\begin{tabular}{lccc}
\hline \hline Classes & \multicolumn{3}{c}{ Abrangência do mercado } \\
\cline { 2 - 4 } & Brasil & $\begin{array}{c}\text { Estado onde o moinho está } \\
\text { sediado }\end{array}$ & $\begin{array}{c}\text { Região em que o moinho } \\
\text { está sediado }\end{array}$ \\
\hline I & 04 & 20 & 13 \\
II & 06 & 02 & 05 \\
III & 04 & 04 & 06 \\
IV & & 02 & 05 \\
V & & 02 & 02 \\
\hline Total & 14 & 30 & 31 \\
\hline
\end{tabular}

Fontes: Dados de pesquisa (1996)

Dados da pesquisa revelam, ainda, que os principais sub-produtos da moagem continuam sendo a farinha e o farelo. No entanto, são importantes também, entre outros, o germe de trigo e a farinha industrial para cola. $O$ farelo tem uma taxa de extração que varia de 20 a $35 \%$. Este sub-produto teve um aumento em sua demanda por parte das indústrias de rações nos últimos 6 anos, o que pode explicar o fato de algumas indústrias trabalharem com a taxa de extração máxima para esse sub-produto. Pelas informações dos moageiros, não existe mais apenas a produção de dois tipos de farinha (comum e especial), mas sim a produção de mais de dez diferentes tipos de farinha, conforme o processo de moagem e a qualidade do grão, em uma nítida estratégia de diferenciação de produtos. Esta diferenciação de farinhas permite, também, a cobrança de diferentes 
preços que, conforme dados coletados, variam de 10 a $30 \%$ a mais, em relação à farinha mais comum.

Em relação às farinhas diferenciadas, do universo dos 76 moinhos pesquisados, sessenta afirmaram que as indústrias consumidoras têm sido mais exigentes neste aspecto.

Quanto à concorrência dos produtos importados derivados da moagem de trigo, 42 moinhos afirmaram que têm sido afetados por estas importações, principalmente dos produtos argentinos, que obtêm tarifas privilegiadas em função do MERCOSUL. As estratégias dos moinhos frente a esta concorrência têm sido variadas destacando-se a redução de preço, melhoria da qualidade, oferta de produtos diferenciados, melhores condições de pagamento, rapidez e a melhoria no atendimento, ampliação da clientela, e até algumas ações intensas de "telemarketing".

Em relação aos investimento em "marketing" e propaganda, 12 moinhos $(15,8 \%)$ declararam não investir nada, $44(57,9 \%)$ pouco e $9(11,8 \%)$ investir bastante. É importante observar que todos os moinhos das classes III, IV e V declararam promover suas vendas através de alguma ação de "marketing".

Algumas unidades moageiras estão associadas ou, até mesmo, são da mesma propriedade de indústrias de transformação (pães, massas e biscoitos). A Tabela 4.30, apresenta o número de moinhos associados a essas indústrias, por classe de moagem. $\mathrm{O}$ moinho que aparece como associado à indústria de transformação na classe I, produz farinha apenas para o abastecimento de uma indústria de massas do mesmo proprietário do moinho. Da mesma forma, o moinho da classe II, pertencente a uma cooperativa de produtores, abastece uma fábrica de biscoitos da própria cooperativa. Na classe III é onde aparece o maior número de moinhos integrados, destacando-se porém que três deles são moinhos pertencentes a grandes grupos industriais. Os moinhos integrados nas classes IV e V ou são pertencentes a grandes grupos ou abastecem suas próprias fábricas de derivados do trigo. 
TABELA 4.30 Número de moinhos associados à indústria de transformação, 1996.

\begin{tabular}{lcc}
\hline \multicolumn{1}{c}{ Classes } & $\mathrm{N}^{0}$ total de moinhos & $\mathrm{N}^{\circ}$ de moinhos associados \\
\hline I & 37 & 01 \\
II & 13 & 01 \\
III & 15 & 06 \\
IV & 07 & 03 \\
V & 04 & 02 \\
\hline Total & 76 & 13 \\
\hline \hline
\end{tabular}

Fonte: Dados da pesquisa (1996) 


\section{CONCLUSÕES}

O mercado de trigo no Brasil sofreu uma alteração radical em suas regras de funcionamento, estabelecidas a partir do Decreto-Lei 210 de 1967, quando em novembro de 1990 o governo decretou a liberação geral do setor, expondo todos os agentes deste Complexo Agroindustrial às regras da livre economia de mercado. Indubitavelmente, o impacto da saída do Estado de um setor, que esteve por longos anos sob sua completa intervenção, ocasionou diversos desdobramentos, tanto na esfera produtiva do grão quanto na comercialização e industrialização do cereal. A partir de então, a falta de regras claras de apoio à triticultura nacional e a exposição à concorrência do trigo importado desarticulou a produção, reduzindo drasticamente a área plantada e a colheita, além de aumentar os dispêndios do País com as importações deste produto e de seus derivados.

A indústria de moagem, foi indubitavelmente um dos setores do CAI tritícola mais afetados com a regulação. Esta, ao constituir-se em uma barreira legal à entrada de novas firmas na indústria, contribuiu para uma maior concentração técnica e econômica do setor de moagem do cereal, além de regulamentar a conduta e o desempenho das empresas ao impedir o funcionamento normal do sistema, disciplinando desde o acesso à matéria prima até a fixação de cotas de moagem e de preços finais dos derivados. Este sistema possibilitou a todas as firmas da indústria, independentemente de seu tamanho, grau de eficiência ou modernização, auferir lucros significativos, mesmo operando, muitas vezes, com elevado grau de ociosidade. Porém, uma vez que o sistema amparava quaisquer ineficiências operacionais, garantindo a rentabilidade do setor, este não sofreu 
um processo contínuo de modernização de equipamentos ou de processos. Assim, no final do anos 90, a elevada concentração, o excesso de capacidade produtiva e um mercado consumidor ainda cativo, eram características importantes da estrutura deste mercado que se impunham como desafios à sobrevivência das firmas na indústria.

A hipótese que após a desregulação do mercado, haveria a entrada de novas firmas na indústria se confirma, haja visto o aumento do número absoluto de moinhos no Brasil de 1987 para 1996. Porém, este dado pode deixar passar despercebido outros importantes movimentos de entrada e saída, que já se pode observar, na indústria. De fato, apesar da entrada de novas unidades, muitas também têm abandonado o setor ou paralisado suas atividades, principalmente os pequenos moinhos situados próximos às regiões produtoras que, além da desvantagem de operar com uma pequena escala de produção, ficam extremamente prejudicados em relação ao acesso à matéria-prima, tendo em vista a desarticulação da produção nacional (em princípio, o principal fornecedor dos pequenos moinhos ainda é o produtor brasileiro), e a desvantagem em relação aos grandes moinhos que, são privilegiados neste aspecto, devido a sua localização (normalmente próximos às regiões portuárias) e suas melhores condições financeiras. Nada obstante, não houve modificações significativas de 1990 para 1996, em relação à distribuição geográfica dos moinhos no parque moageiro nacional, continuando a prevalecer os grandes moinhos nas proximidades dos grandes centros urbanos e/ou portos marítimos e a grande dispersão de tamanho de plantas, destacando-se as pequenas unidades, nas proximidades das regiões produtoras do Sul do País.

A concentração técnica, reduziu-se em algumas regiões, tendo em vista o aumento do número absoluto de moinhos e a expansão da capacidade de moagem dos moinhos já estabelecidos no mercado. Porém, esta expansão tem aumentado o nível de capacidade ociosa da indústria, tendendo a ser mais elevada nas pequenas unidades que não conseguem aproveitar todas as economias de operação de uma grande planta. 
O que se observa, no entanto, é um grande aumento do nível de concentração econômica do setor com o número de firmas ligadas a grandes grupos aumentando significativamente.

Os grandes grupos e conglomerados têm avançado na conquista de mercado, principalmente através do processo de aquisição de firmas. Estas aquisições têm possibilitado a estes vencer os limites impostos pela expansão da demanda, ao penetrar em outros mercados regionais.

A expansão da indústria é condicionada aos seus lucros e, como salientado, ao ritmo de expansão da demanda de mercado. Sem dúvida, uma firma só investirá em expansão se tiver recursos para tal e, se houver demanda para esta oferta excedente. As firmas ligadas a grandes grupos podem não ter nos lucros um limite a sua expansão, tendo em vista que suas estratégias de crescimento, muitas vezes, estão condicionadas às do grupo que, a não ser que tenha outros investimentos com taxas de retorno mais atrativas, não têm outra alternativa se não reinvestir seus lucros acumulados nas suas próprias empresas associadas.

Como visto, a demanda brasileira ainda é muito cativa. Porém, este crescimento potencial da demanda é possível de ser atendido apenas pela oferta atual da indústria de moagem, sem necessidade de maiores expansões, no curto prazo. Assim, é possível que, caso esta expansão da demanda demore a ocorrer, a indústria continue a operar com elevada capacidade ociosa. Neste sentido, as unidades que tiverem maior "fôlego" financeiro poderão sustentar-se no mercado e neste aspecto a vantagem das grandes firmas, principalmente aquelas ligadas aos grandes grupos, é extremamente elevada em relação aos pequenos moinhos. Neste particular, constitui-se estratégia importante de crescimento para vencer este limite de expansão, as já citadas aquisições, e até mesmo os arrendamentos de unidades moageiras, por parte dos grandes conglomerados. Além de não terem os riscos associados à abertura de uma nova unidade, estas reduzem o grau de 
capacidade da indústria como um todo, ao expandirem-se através da incorporação do mercado de um moinho já existente, eliminando assim um concorrente do mercado.

A disputa pela venda de farinhas e pela aquisição da matéria-prima no mercado externo e interno tem exigido profundas modificações nas atitudes comerciais e gerenciais das empresas de moagem. Neste aspecto, destaquem-se, mais uma vez, as vantagens dos grandes moinhos que podem oferecer melhores condições de preço e prazo para pagamento, devido aos seus maiores recursos para capital de giro, além do privilegiado acesso à matéria-prima, principalmente a importada, que permite a estes ofertarem farinhas diferenciadas, hoje uma exigência das indústrias processadoras. Além disto, muitas destas grandes unidades são associadas ou proprietárias de algumas indústrias de transformação, o que lhes garante o escoamento de parte de sua produção. As pequenas unidades já sentem as dificuldades de operar neste mercado restrito, mesmo aproveitando alguns "nichos" de mercado. Algumas alternativas têm dito respeito à associação do moinho a alguma indústria processadora.

O ambiente de economia de mercado que se impôs sobre a indústria de moagem no Brasil, após a desregulação do mercado, abre novas oportunidades às empresas, principalmente através de ações integradas com as indústrias de transformação que deverão atender às novas demandas de um consumidor cada vez mais exigente. A abertura comercial $\mathrm{e}$ a ampliação do mercado interno a partir do estabelecimento do Plano Real possibilitaram o crescimento dos investimentos em pesquisa e desenvolvimento de novos produtos, marketing e equipamentos para expansão e modernização do setor. As inovações tecnológicas nas fases de descarregamento do trigo em grão, ensacamento e ensilagem de farinha que já se verificam permitem, por exemplo, uma estratégia de diferenciação de farinhas por parte da indústria.

O treinamento e qualificação da mão-de-obra é uma forma, também, de melhorar o processo e, conseqüentemente, possibilitar a fabricação de um produto de mais alta qualidade. Neste sentido, exemplos como o do Centro de Treinamento de Moagem e Panificação de Fortaleza (um dos únicos no gênero na América latina) e do Projeto "Melhoria do Processo 
Produtivo da Micro e Pequena Indústria Moageira de Trigo do Noroeste do Rio Grande do Sul" são importantes para a indústria nacional (principalmente a pequena) adquirir condições de competitividade internacional.

Estes investimentos na modernização de todo o processo de moagem e a conseqüente melhoria da competitividade, devem abrir novas oportunidades, inclusive com a possibilidade de expansão em direção ao mercado externo, na busca de escoadouros para o crescimento das firmas na indústria. 


\section{REFERÊNCIAS BIBLIOGRÁFICAS}

ABREU, M. P.; LOYO, E. H. M. M. Globalização e regionalização: tendências da economia mundial e seu impacto sobre os interesses brasileiros. Estudos de Política Agrícola n.5, ’p. 1-142, 1994 (Projeto PNUD/BRASIL).

ALMEIDA, F. R. de F. O trigo brasileiro e os novos tempos. Conjuntura Econômica, v.47, n.2, p.65-67, fev. 1993.

ALVES, J. G. Aspectos da evolução da produção e da pesquisa de trigo no Brasil. Campinas, 1991.Tese (Doutorado) - Universidade Estadual de Campinas.

ARAÚJO, N. B. et al. Complexo agroindustrial: O “ggribusiness" brasileiro . São Paulo: Agroceres, 1992. 238p.

ARAÚJO, N. B.; PINAZZA, L. A. A agricultura na virada do Séc. XX (visão de agribusiness). São Paulo: Globo, 1993. 166p.

BAIN, J. S. Industrial organization. New York: John wiley \& Sons, 1958. 678p.

BALANÇO ANUAL. GAZETA MERCANTIL. São Paulo, 19 -

BARROS, G. S. de C. Mercados contestáveis: Uma introdução. Série Didática. DESR/ESALQ, n.79, p.1-14, 1993. 
BAUMOL, W. J. Contestable markets: An uprising in the theory of industry structure. American Economic Review, v.73, n.3, p.491-496, 1983.

BAUMOL, W. J.; PANZAR, J. C.; WILLIG, R. D. Contestable Markets and the theory of industry structure. San Diego: Harcourt, 1988. 538p.

BAUMOL, W. J.; WILLIG, R. D. Contestability: developments since the book. Economic Papers, v.38, p.352-497, 1986.

BATISTA, J. C. Estrutura industrial e competição no setor de moagem de trigo no Brasil, Rio de Janeiro, 1980. 194p. Dissertação (Mestrado) - COPPE/Universidade Federal do Rio de Janeiro.

BOLETIM DO BANCO CENTRAL. Brasília, 19-

BURNQUIST, H. L. et al. Liberação comercial: um fator de desenvolvimento do setor agrícola brasileiro. Estudos de Política Agrícola n.14, p. 1-216, 1994. (Projeto PNUD/BRASIL).

CARMO, A. J. B. do. Tecnologia e competitividade na indústria brasileira de fertilizantes fosfatados. São Paulo, 1994. 223p. Tese (Doutorado) - Faculdade de Economia Administração e Contabilidade da Universidade de São Paulo.

CAVES, R. Estrutura industrial americana, Rio de Janeiro: Zahar, 1967. 180p.

COELHO, CARLOS N. de. A organização do sistema de comercialização e desenvolvimento econômico. Brasília: Coleção Análise e pesquisa, v. 18, p. 1-63, 1979. 
CONJUNTURA ECONÔMICA. Rio de Janeiro, 19 -

DUARTE, A. R. Tecnologia na agricultura: considerações sobre a produtividade do trigo brasileiro. São Paulo, 1974. 144p. Dissertação (Mestrado) - Faculdade de Economia Administração e Contabilidade da Universidade de São Paulo.

EXAME. São Paulo, 19 - (melhores e maiores).

FARINA, E. M. M. Q.; SHEMBRI, Desregulação: a experiência norte-americana. Pesquisa e Planejamento Econômico, v.20, n.2, p.325-352, 1990.

FARINA, E. M. M. Q. Moinho Pacífico: Ajustamentos a realidade do livre mercado. São Paulo: PENSA, v.6, p. 1-11, 1993.

FARINA, E. M. M. Organização Industrial. São Paulo, FEA-USP, 1994, (Mimeo)

FARINA, E. M. M. Q.; ZYLBERSZTAJN, D. Relações tecnológicas e organização dos mercados no sistema agroindustrial de alimentos. In: SEMINÁRIO INTERNACIONAL DE POLÍTICA AGRÍCOLA, 2, Viçosa. Anais. Viçosa: UFV, 1992. p.73-94

FARINA, E. M. M. Q. A regulação do mercado de leite e laticínios no Brasil. São Paulo: Instituto de Pesquisas Econômicas, 1983. 119p.

FERGUSON, C. E. Microeconomia. 4 ed. Rio de Janeiro: Forense, 1981. 610 p.

FREITAS, L. M.; DELFIM NETTO, A. O trigo no Brasil. São Paulo, Associação Comercial de São Paulo, 1960. 
GANDOLFO C. C. Análise e perspectiva do trigo no Brasil. Revista de Economia Rural, v.15, t. 1, p.159-191, 1977.

GIL, A. C. Técnicas de pesquisa em economia. São Paulo: Atlas, 1991. 195 p.

GUIMARÃES, E. A. Acumulação e crescimento da firma: um estudo de OI. Rio de Janeiro: Guanabara, 1987. 196p.

GUIMARÃES, E. P. et al. O impacto do NAFTA sobre as relações do Brasil com a América Setentrional: O caso dos produtos agrícolas. Estudos de Política Agrícola, n.18, 1994. (Projeto PNUD/BRASIL)

HAMMERSCHIMIDT, B. Eficiência econômica de comercialização de trigo em cooperativas agrícolas, no estado do Paraná. Viçosa, 1973. 105p. Dissertação (Mestrado) Universidade Federal de Viçosa.

HUBNER, O. Culturas de inverno; trigo. Acompanhamento da situação agropecuária do Paraná, v. 22, n. 4, p. 29-37, abr./maio 1996.

INFORMAÇÕES ECONÔMICAS. São Paulo, 19 -

INFORMAÇÕES FIPE. São Paulo, 19 -

$\mathrm{KOCH}, \mathrm{J} . \mathrm{V}$. Industrial organization and prices. 2 ed., New Jersey: Englewood Cliffs, 1980. 504p.

LABINI, P. S. Oligopólio e progresso técnico. Rio de Janeiro: Forense Universitária, 1980. $306 \mathrm{p}$. 
LORENZON, G. O pão que o Canadá amassou. MERCOSUL: Revista de Negócios, n.23, p.55-57, 1993.

MANDARINO, J. M. G. Aspectos importantes para a qualidade do trigo. Londrina: EMBRAPA-CNPS, 1993. 32p.

MARQUES, P. V. Economia da integração vertical na avicultura de corte no estado de São Paulo. Piracicaba, 1991. 133p.. Tese (Livre Docência) - Escola Superior de Agricultura Luiz de Queiroz, Universidade de São Paulo.

MELO, F. H. O Governo está prejudicando o trigo nacional. Informações FIPE, n.153, p.19-20, jun. 1993.

MENDES, A. G. et al. Liberação de mercado e integração econômica no MERCOSUL: estudo de caso sobre o CAI tritícola. Estudos de Política Agrícola, n.10, p.1-172, 1994.(Projeto PNUD/BRASI).

MUNHOZ, R. R. O mercado de exportação de trigo argentino: hipóteses de desequilíbrio e suas implicações. Viçosa, 1989. Tese (Doutorado) - Universidade Federal de Viçosa.

OSÓRIO, E. A. A cultura do trigo, Coleção do agricultor-Grãos: Globo Rural, 1992.

PENROSE, E. T. The theory of the growth of the firm. Oxford: Basil Blackwell, 1972.

PINDYCK, R. S.; RUBINFELD, D. L. Microeconomia. São Paulo: Makron Books, 1994. 968p.

PORTER, M. The competitive advantage of nations. New York: Free Press, 1990. 855p. 
ROCHA JR. W. F. Utilização do suco de laranja concentrado (SLCC) em concessionárias de refeições coletivas, Piracicaba, 1994. Dissertação (Mestrado) - Escola Superior de Agricultura Luiz de Queiroz, Universidade de São Paulo. 101p.

SHERER, F. M.; ROSS D. Industrial market structure and economic performance. 3.ed. Boston: Houghton Mifflin, 1990. 713p.

SCHUMPETER, J. Capitalismo, socialismo e democracia. São Paulo: Zahar, 1994. 534p.

SILVA, C. R. L. da. O impacto da política comercial brasileira na agricultura. São Paulo, 1986. 97p. Dissertação (Mestrado) - Faculdade de Economia Administração e Contabilidade da Universidade de São Paulo.

SILVA, V. M. da. A Regulação do mercado brasileiro de trigo. São Paulo, 1989. 179p. Dissertação (Mestrado) - Faculdade de Economia Administração e Contabilidade da Universidade de São Paulo.

SOARES, R. P. Avaliação econômica da política tritícola de 1967 a 1977, Brasília: Coleção Análise e Pesquisa, v.20, p. 1-139, 1980.

STEINDL, J. Maturity and stagnation in american capitalism. 2 ed. Oxford: Blackwell, 1976.

STIGLER, G. J. The organization of industry. Homewood : Richard D. Irwin, Inc, 1968.

STÜLP, V. J. Tecnologia, custos e competitividade no MERCOSUL: casos do trigo, soja, milho e arroz. Estudos Avançados: A Integração Regional e o MERCOSUL, p.95123, nov. 1992. 
SUZUKI JÚNIOR, J. T. Panorama da triticultura paranaense e brasileira. Análise Conjuntural, v.17, n. 5/6, p.11-14, jun. 1995.

TIROLE, J. The theory of industrial organization. Cambridge: The MIT Press, 1988. $479 \mathrm{p}$.

VARIAN, H. R. Microeconomia: Princípios básicos, 2 ed. Rio de Janeiro: Campus, 1994. $710 \mathrm{p}$.

VASCONCELOS, C. R. F. Impactos setoriais de mudanças na demanda final da agricultura. Viçosa, 1992. Dissertação (Mestrado) - Universidade Federal de Viçosa.

VEGRO, C. L. R.; SATO, G. S. Fusões e aquisições no setor de produtos alimentares, Informações Econômicas, v.25, n. 5, p. 9-21, maio 1995.

VISÃO. QUEM É QUEM NA ECONOMIA BRASILEIRA. São Paulo: DCI., 1989-1992.

VITAL, T. W.; SAMPAIO, Y. Abastecimento e consumo de trigo no Brasil: situação recente 1980/1992. In: CONGRESSO DA SOCIEDADE BRASILEIRA DE ECONOMIA E SOCIOLOGIA RURAL, 31, Ilhéus, 1993. Anais. v.1, p.359-371.

WILLIAMSOM, O. Economic organization: Firms, Markets and policy control. New York: University Press, 1966.

WILLIAMSOM, O. The economic institutions of capitalism. New York: The free press, 1985. 450p. 
ANEXO 1: Questionário aplicado aos moinhos brasileiros em 1996.

\section{IMPORTANTE}

“AS INFORMAÇÕES COLHIDAS PELO PRESENTE QUESTIONARIO SERÃO CONFIDENCIAIS E UTILIZADAS APENAS PARA FINS DE PESQUISA EM UMA ANALISE GLOBAL E NÃO INDIVIDUALIZADA POR EMPRESA"

- Por favor, responda o questionário de forma completa o mais rápido possível.

- Se você não souber, ou não estiver clara alguma questão, deixe em branco.

- Em algumas questões alternativas podem ser assinaladas mais de uma alternativa.

- Em cada questão é possível fazer qualquer tipo de comentário que achar necessário.

- Coloque o questionário no envelope anexo e posteriormente no correio.

1. A sua empresa já atuava, à época do mercado regulado (1967/1990), com a moagem de trigo? $\square \operatorname{sim} \quad \square$ não

2. O seu moinho fica próximo a região produtora de trigo? (considere a distância de até $100 \mathrm{~km}$ da região produtora) $\quad \square$ sim $\quad \square$ não

3. O seu moinho fica próximo a um centro consumidor de médio ou grande porte? (considere cidades com 300 mil ou mais habitantes) $\quad \square$ sim $\quad \square$ não

4. O seu moinho fica próximo a região portuária? (considere próximo se o seu moinho fica a uma distância de até $150 \mathrm{~km}$ do porto marítimo mais próximo)

$\square \operatorname{sim} \square$ não

5. Qual a capacidade de moagem atual de sua empresa? $(\mathrm{kg} / 24 \mathrm{~h})$.

6. Qual a capacidade atual de estocagem de trigo em grão da sua empresa? (toneladas)

7. Qual a capacidade atual de estocagem de farinha de trigo da sua empresa? (toneladas)

8. Qual é a moagem real de trigo diária de sua empresa ? (média em $\mathrm{kg} / 24 \mathrm{~h}$ ).

9. A sua empresa expandiu a capacidade de moagem nos últimos 06 anos?
$\square \operatorname{sim}$ não

10. De quanto foi esta expansão de capacidade de moagem? $(\mathrm{kg} / 24 \mathrm{~h})$. 


\section{ANEXO 1 (CONT.)}

11. A sua empresa tem algum projeto de ampliação da capacidade de moagem?
$\square \operatorname{sim}$
não

12. De quanto seria esta ampliação? $(\mathrm{kg} / 24 \mathrm{~h})$

13. A sua empresa modificou a sua estrutura organizacional nos últimos 06 anos?

$\square \operatorname{sim} \quad \square$ não

14. Quantos funcionários trabalham no setor operacional de seu moinho?

15. Quantos funcionários trabalham no setor administrativo do moinho?

16. A sua empresa utiliza mão de obra familiar? $\square \operatorname{sim} \quad \square$ não

17. A sua empresa ofereceu algum tipo de treinamento para os funcionários do setor de moagem do grão, nos últimos 06 anos? $\square$ sim $\square$ não

18. A sua empresa adquiriu máquinas e equipamentos para renovação ou modernização do setor de moagem do grão nos últimos 06 anos? $\square \operatorname{sim} \quad \square$ não

19. A sua empresa fez investimentos no setor de armazenagem nos últimos 06 anos?

$\square \operatorname{sim} \quad \square$ não

* 20. A etapa de descarregamento do trigo é manual, parcialmente automatizada, ou totalmente automatizada?

21. A etapa de ensacamento e ensilagem é manual, parcialmente automatizada ou totalmente automatizada?

22. A sua empresa adquire trigo em grão Importado?

$\square \operatorname{sim} \quad \square$ não

23. Qual o percentual de trigo importado utilizado por sua empresa em relação ao total de trigo moído? (em \%) 


\section{ANEXO 1 (CONT.)}

24.. Se sua empresa adquire trigo em grão importado, qual a origem do cereal? Numere os países fornecedores em ordem crescente, de acordo com a quantidade adquirida de cada país fornecedor ( por exemplo, se o seu maior fornecedor for os EUA, coloque o número 1 no $1^{\circ}$ quadrinho)

$\square$ EUA

Canadá

Argentina

$\square$ Outro País. Citar:

25. Numere os seus principais fornecedores de trigo em grão em ordem crescente de acordo com a quantidade adquirida de trigo (ex: se você adquire a maior parte de seu trigo diretamente dos produtores, coloque o número 1 no $1^{\circ}$ quadrinho)

$\square$ produtor nacional

$\square$ cooperativas

$\square$ Importado

$\square$ corretores

$\square$ Governo

$\square$ Outro fornecedor. Citar:

26. A empresa realiza contratos antecipados de compra de trigo em grão de forma a ter garantido o suprimento de matéria-prima com:

$\square$ cooperativas

$\square$ produtores agrícolas

$\square$ importadores

$\square$ outros. Citar:

$\square$ não realiza contratos antecipados de compra de trigo

27. Ao comprar o trigo para moagem a sua empresa leva em consideração? (numere na ordem de importância)

as condições comerciais mais favoráveis

a qualidade do grão

$\square$ o tipo e a diversidade do grão para a preparação de "blends" específicos. 


\section{ANEXO 1 (CONT.)}

28. Quais os principais subprodutos da moagem de trigo que seu moinho produz?

$\square$ farelinho de trigo

$\square$ farinha de trigo

$\square$ outros. Citar:

29. Assinale os subprodutos extraídos da moagem do trigo citando o percentual de cada subproduto da moagem no mix de produto final. (Ex: A taxa de extração do farelo de trigo é $0,33 \%$ em média, ou seja do total de trigo em grão moído $0,33 \%$ é produção de farelo)

$\square$ farinha de trigo comum.___ $\%$

$\square$ farinha de trigo especial____ $\%$

$\square$ farelo de trigo__ $\%$

$\square$ outro subproduto (citar) ___ $\%$

30. Se o seu moinho produz farinha especial, qual é o percentual de diferença de preço em comparação a farinha comum?

31. Houve aumento da demanda por seu farelo de trigo nos últimos 06 anos?

$\square \operatorname{sim} \square$ não

32. Assinale os seus principais compradores: ( numere na ordem de importância)

mercado varejista

cooperativas

$\square$ supermercados

$\square$ indústrias de massas

$\square$ indústrias de rações

$\square$ indústria de biscoitos

$\square$ outros. Citar:

33. Sua clientela é: (numere na ordem de importância)

variada

variada privilegiando os pequenos compradores

variada privilegiando os grandes compradores

apenas grandes compradores

apenas pequenos compradores 


\section{ANEXO 1 (CONT.)}

34. Qual o mercado comprador dos produtos de sua empresa?

todo o Brasil .

apenas o estado em que está situado o moinho.

$\square$ apenas a região do Brasil em que está situado o moinho.

35. A sua empresa tem sido afetada de alguma forma pela concorrência dos produtos importados (como por exemplo, massas e biscoitos da Itália e da Argentina).

$\square \operatorname{sim} \quad \square$ não

36. Frente a essa concorrência das importações o que tem feito sua empresa?

$\square$ oferecido produto diferenciado

$\square$ reduzido o preço

$\square$ oferecido melhores condições de pagamento

$\square$ outra estratégia. Citar:

$\square$ minha empresa não tem sido afetada pelas importações.

37. As indústrias consumidoras de derivados de trigo tem exigido farinhas diferenciadas? (blends diferenciados) $\quad \square \operatorname{sim} \quad \square$ não

38. A sua empresa está associada a alguma indústria de pães, massas ou biscoitos?

$\square \operatorname{sim} \quad \square$ não

39. Cite o tipo de indústria que sua empresa está associada:

40. A sua empresa realiza algum tipo de análise da qualidade da matéria-prima e do produto final? $\quad \square \operatorname{sim} \quad \square$ não

41. A empresa possui algum sistema de informações sobre câmbio e oferta de trigo em grão em vários mercados? $\quad \square$ sim $\quad \square$ não 


\section{ANEXO 1 (CONT.)}

42. A sua empresa investe em Marketing?

$\square$ Nada

$\square$ Pouco

$\square$ Bastante

43. Outros esclarecimentos ou sugestões que julgar necessários:

\section{OBRIGADO PELA COLABORAÇÃO}


ANEXO 2: Relação do moinhos que responderam ao questionário aplicado, por regiões do Brasil, 1996.

\begin{tabular}{|c|c|c|}
\hline Região & Moinhos & Cidade/Estado \\
\hline Norte & $\begin{array}{l}\text { Indústria Moageira de Trigo Amazonas S.A.(G.Ocrim) } \\
\text { Ocrim S.A. Produtos Alimentícios (Grupo Ocrim) }\end{array}$ & $\begin{array}{l}\text { Manaus - AM } \\
\text { Belém - PA }\end{array}$ \\
\hline Nordeste & $\begin{array}{l}\text { Santista Alimentos S.A. (G. Santista) } \\
\text { Santista Alimentos S.A. (G. Santista) } \\
\text { S.A Moinho da Bahia.Promessa de compra da Santista }\end{array}$ & $\begin{array}{l}\text { Cabedelo - PB } \\
\text { Natal - RN } \\
\text { Salvador - BA }\end{array}$ \\
\hline Centro Oeste & $\begin{array}{l}\text { Cerealista e Moinho Dallas Ltda (G. Dallas) } \\
\text { Arno Werner Máquinas e Motores Ltda } \\
\text { Domingos Costa Ind. Alimentícias S/A }\end{array}$ & $\begin{array}{l}\text { Nova Alvorada - MS } \\
\text { Dourados - MS } \\
\text { Contagem - MG }\end{array}$ \\
\hline Sudeste & $\begin{array}{l}\text { Indústrias Reunidas Marilu S/A (Grupo Santista) } \\
\text { Buaiz S.A. Indústria e Comércio (G. Buaiz) } \\
\text { Indústrias Reunidas São Jorge S/A } \\
\text { Lapa Alimentos S.A (Grupo J. Macedo) } \\
\text { Moinho Água Branca S.A. } \\
\text { Moinho Pacífico Ind. e Comércio Ltda } \\
\text { Ocrim S.A. Produtos Alimentícios (G. Ocrim) } \\
\text { Pena Branca Alimentos do Sul S/A (G. Pena Branca) } \\
\text { São Valentin Agro-Industrial Ltda (C.Cargil Agricola) }\end{array}$ & $\begin{array}{l}\text { Rio de Janeiro - RJ } \\
\text { Vitória - ES } \\
\text { São Paulo - SP } \\
\text { Santos - SP } \\
\text { São Paulo - SP } \\
\text { São Paulo SP } \\
\text { São Paulo - SP } \\
\text { São Paulo - SP } \\
\text { Tatuí - SP } \\
\end{array}$ \\
\hline Sul & $\begin{array}{l}\text { Badotti Agro-Industrial do Paraná Ltda } \\
\text { Cooper. Agraria Mista Entre Rios Ltda } \\
\text { Cooper. Agrop. Mista Laranjeiras do Sul } \\
\text { Cooper. Agropecuária Mourãoense Ltda } \\
\text { Cooperativa Central Regional Iguaçu Ltda } \\
\text { Indústria de Alimentos Tradição Ltda } \\
\text { Moinho Agrícola Horizonte Ltda } \\
\text { Moinho Curitibano S.A (arrendado a Santista-parado) } \\
\text { Moinho de Trigo 2 N Ltda } \\
\text { Moinho de Trigo Arapongas Ltda } \\
\text { Moinho de Trigo e Pastificio Oeste Ltda } \\
\text { Moinho São Luiz Ltda } \\
\text { Antoniazzi \& Cia Ltda } \\
\text { Armando Menegaz \& Cia Ltda } \\
\text { Benjamin Zago - Indústria Moageira Ltda } \\
\text { Bernardo Jaeschke \& Filhos Ltda } \\
\text { Coop. Agrícola Mista Nova Palma Ltda } \\
\text { Coop. Agropecuária Caxiense Ltda } \\
\text { Cooperativa Mista São Luiz Ltda } \\
\text { Coop. Triticola de Getulio Vargas Ltda } \\
\text { Coop. Tritícola de Rosário do Sul Ltda (Parado) } \\
\text { Cooperativa Triticola Erechim Ltda } \\
\text { Cooperativa Triticola Palmeirense Ltda }\end{array}$ & $\begin{array}{l}\text { Cascavel - PR } \\
\text { Guarapuava - PR } \\
\text { Laranj. do Sul - PR } \\
\text { Campo Mourão - PR } \\
\text { Palotina - PR } \\
\text { Cascavel - PR } \\
\text { Mal. C.Rondon - PR } \\
\text { Curitiba - PR } \\
\text { Ivaiporã - PR } \\
\text { Arapongas - PR } \\
\text { Pato Branco - PR } \\
\text { Guarapuava - PR } \\
\text { Santa Maria - RS } \\
\text { Passo Fundo - RS } \\
\text { Faxinal do Soturnol RS } \\
\text { Cerro Largo - RS } \\
\text { São João PolesinelRS } \\
\text { Caxias do Sul -RS } \\
\text { Santa Rosa - RS } \\
\text { Estação - RS } \\
\text { Rosário do Sul - RS } \\
\text { Erechim - RS } \\
\text { Palm. das Missões } L S S\end{array}$ \\
\hline
\end{tabular}




\section{ANEXO 2 (CONT)}

Coop. Triticola Reg. Santo Angelo Ltda

E. Walter \& Cia Ltda

Franzoi \& Cia Ltda

Furian Bergoli Ind. e Com. de Cer. Ltda

Granja Santo Isidro Ltda (parado)

Guindani S.A. Ind. e Comércio (arrendado a Santista)

Gustavo Jão Olson \& Filhos Ltda

Irmãos Tres \& Cia Ltda

Maurício Litvin \& Filhos Ltda

Moinho 15 de Novembro Ltda

Moinho Brasil Ltda

Moinho da Fronteira Ltda

Moinho do Nordeste S.A.

Moinho Vacaria Industrial e Agrícola Ltda

Moinho Vicato Indústria e Comércio

Moinhos Cruzeiro do Sul S/A

Sangalli, Busa S/A Ind. e Agropecuária

Stella \& Cia Ltda

Tillmann S/A Indústria e Comércio Imob.

Sul

Comercial e Industrial Antonio Viel Ltda

Coop. Regional Agrop. de Campos Novos

Cooperativa Regional Alfa Ltda

Coop. Triticola Rio do Peixe Ltda

Fuganti S.A. Indústria e Comércio

Leopoldo Weiss Ltda

Lunardi Alimentos Ltda

Moinho Cruzeiro Ltda

Moinho Martelli Ltda

J. Macedo S.A. (G. J. Macedo)

Moinho União Ltda

Moinho Videira Ltda

Moinhos Trigoflor Ltda

Paulo Fleischmann \& Cia Ltda

S.A. Maffessoni Comércio e Indústria

Specht Produtos Alimentícios Ltda

Santo Angelo - RS

Ijui - RS

Caxias do Sul - RS

Pejuçara - RS

Boqueirão do LeãolRS

Canoas - RS

Camaquã - RS

Pinhal - RS

Erechim - RS

Ibirubá - RS

Encantado - RS

Porto Alegre - RS

Antonio Prado - RS

Vacaria - RS

Sananduva - RS

Canoas - RS

Encantado - RS

Pejuçara - RS

Pelotas - RS

Santo Angelo - RS

Lacerdópolis - SC

Erval Velho - SC

Chapecó - SC

Joaçaba - SC

Tangara - SC

São Bento do Sul-SC

Xaxim - SC

Lages - SC

Coronel Freitas - SC

Itajaí - SC

Pinheiro Preto -SC

Videira - SC

Joaçaba - SC

Mafra - SC

Caçador - SC

Joaçaba - SC

Fonte: Dados da pesquisa (1996) 
ANEXO 3: Relação de moinhos brasileiros, por zonas de consumo, 1996

\begin{tabular}{c|l|l}
\hline \hline $\begin{array}{c}\text { Zonas de } \\
\text { consumo }\end{array}$ & \multicolumn{1}{|c}{ Moinhos } & \multicolumn{1}{|c}{ Cidade/Estado } \\
\hline \multirow{3}{*}{1} & $\begin{array}{l}\text { Indústria Moageira de Trigo Amazonas S.A. } \\
\text { Pena Branca Alimentos S.A. } \\
\text { Ocrim S.A. Produtos Alimentícios } \\
\text { Pena Branca Alimentos S.A. }\end{array}$ & $\begin{array}{l}\text { Manaus - AM } \\
\text { São Luis - MA } \\
\text { Belém - PA } \\
\text { Belém - PA }\end{array}$ \\
\hline \multirow{5}{*}{2} & $\begin{array}{l}\text { Empresa Coml. e Indl. de Prod. Vegetais Ltda } \\
\text { Grande Moinho Cearense S.A }\end{array}$ & Fortaleza - CE \\
& J. Macedo Alimentos S.A & Fortaleza - CE \\
& Santista Alimentos S.A. & Fortaleza - CE \\
& Companhia Produtos Pilar & Cabedelo - PB \\
& Pena Branca Alimentos S/A & Recife - PE \\
& Santista Alimentos S.A. & Olinda - PE \\
& Santista Alimentos S.A. & Recife - PE \\
Natal - RN
\end{tabular}




\section{ANEXO 3 (CONT)}

Indústria de Alimentos Tradição Ltda Indústria e Comércio de Trigo Mariópolis Indústria Moageira Cidade Alta Ltda

Irmãos Massignan \& Cia Ltda

Miguel Lesnioviski Trigo

Moinho Agrícola Horizonte Ltda

Moinho Boa Vista Ltda

Moinho Bom Sucesso Ltda

Moinho Carlos Guth Ltda

Moinho Curitibano S.A? .

Moinho Dallagnoll Ltda

Moinho de Trigo $2 \mathrm{~N}$ Ltda

Moinho de Trigo Arapongas Ltda

MOESTEL-Moinho de Trigo Oeste Ind. Com. Itda

Moinho de Trigo Fabulla Ltda

Moinho de Trigo Pontagrossense Ltda

Moinho de Trigo Rotta Ltda

Moinho Globo Indústria e Comércio Ltda

Moinho Graciosa Ltda

Moinho Henke Ltda

Moinho Itaipú S/A

J. Macedo Alimentos S.A.

Moinho Ouro Branco Ltda

Moinho São Luiz Ltda

Moinho Tupy Ltda

S.A. Moageira e Agrícola

Sacopan - Moinho Comercial Ltda

Santista Alimentos S/A

Sperafico Moinhos Ltda

Anaconda Indl. e Agrícola de Cereais S/A

Braswey S.A. - Indútria e Comércio

Indústrias Reunidas São Jorge S/A

Lapa Alimentos S.A

Lapa Alimentos S.A

Moinho Água Branca S.A.

Moinho de Trigo Santo André S.A.

Plus Vita S.A.

Moinho Jundiaí S.A.

Moinho Pacífico Ind. e Comércio Ltda

Moinho Paulista Ltda

Moinho Reisa Ltda

Ocrim S.A. Produtos Alimentícios

Ocrim S.A. Produtos Alimentícios

Pastificio Selmi S.A.

Pena Branca Alimentos S/A

Richard Saigh Indústria e Comércio S.A.

\begin{tabular}{|l} 
Cascavel - PR \\
Mariópolis - PR \\
Apucarana - PR \\
Pinhais - PR \\
Contenda - PR \\
Mal. C.Rondon - PR \\
Pien - PR \\
Bom Suc.do Sul - PR \\
Curitiba - PR \\
Curitiba - PR \\
Cap. L. Marques - PR \\
Ivaiporã - PR \\
Arapongas - PR \\
Pato Branco - PR \\
Japura - PR \\
Ponta Grossa - PR \\
Matelândia - PR \\
Sertanópolis - PR \\
Curitiba - PR \\
Mal. C.Rondon - PR \\
S.Terez.do Itaipú-PR \\
Londrina - PR \\
Santa Fé - PR \\
Guarapuava - PR \\
União da Vitória - PR \\
Irati - PR \\
Coronel Vivida - PR \\
Ponta Grossa - PR \\
Toledo - PR \\
São Paulo - SP \\
Campinas - SP \\
São Paulo - SP \\
Santos - SP \\
São Paulo - SP \\
São Paulo - SP \\
Santo André - SP \\
Santo André - SP \\
Jundiaí - SP \\
São Paulo SP \\
Santos - SP \\
Guarulhos - SP \\
São Paulo - SP \\
Nova Odessa - SP \\
Campinas - SP \\
São Paulo - SP \\
Saulo - SP \\
SRo Pa
\end{tabular}


ANEXO 3 (CONT)

\begin{tabular}{|c|c|c|}
\hline & $\begin{array}{l}\text { Santa Cruz S/A Adm. Merc. e Industrial } \\
\text { Santista Alimentos S.A. } \\
\text { São Valentin Agro-Industrial Ltda }\end{array}$ & $\begin{array}{l}\text { São Paulo - SP } \\
\text { Santos - SP } \\
\text { Tatuí - SP }\end{array}$ \\
\hline 8 & $\begin{array}{l}\text { Adelino Antoniazzi Ind. Moageira Ltda } \\
\text { Alberto Furian \& Cia Ltda } \\
\text { Antoniazzi \& Cia Ltda } \\
\text { Armando Menegaz \& Cia Ltda } \\
\text { Bacchim Lewis Ind. Com. Agr. Mineração Ltda } \\
\text { Benjamin Zago - Indústria Moageira Ltda } \\
\text { Bernardo Jaeschke \& Filhos Ltda } \\
\text { Cerealista Girua Ltda } \\
\text { Cerealista Sepeense Ltda } \\
\text { Comércio de Cereais Brandatti Ltda } \\
\text { Cooperativa Agricola Cairu Ltda } \\
\text { Coop. Agrícola Mista Ibiraiaras Ltda } \\
\text { Coop. Agricola Mista Nova Palma Ltda } \\
\text { Coop. Agricola Mista Rio Branco Ltda } \\
\text { Coop. Agropecuária Caxiense Ltda } \\
\text { Coop. Agropecuária São Jorge Ltda } \\
\text { Cooperativa Mista São Luiz Ltda } \\
\text { Cooperativa Santa Clara Ltda } \\
\text { Coop. Triticola de Getulio Vargas Ltda } \\
\text { Coop. Triticola de Julio de Castilhos Ltda } \\
\text { Coop. Triticola de Passo Fundo Ltda } \\
\text { Cooperativa Triticola Erechim Ltda } \\
\text { Cooperativa Triticola Palmeirense Ltda } \\
\text { Coop. Triticola Reg. Santo Angelo Ltda } \\
\text { E. Walter \& Cia Ltda } \\
\text { Franzoi \& Cia Ltda } \\
\text { Furian Bergoli Ind. e Com. de Cer. Ltda } \\
\text { Granja Santo Isidro Ltda } \\
\text { Guindani S.A. Ind. e Comércio }{ }^{4} \\
\text { Gustavo Jão Olson \& Filhos Ltda } \\
\text { H. Milanesi \& Cia Ltda } \\
\text { Importadora e Exportadora de Cereais S/A } \\
\text { Ind. de Ben. de Cereal Rosa Poles Ltda } \\
\text { Ind. e Com. de Alimentos Araçá Ltda } \\
\text { Irmãos Tres \& Cia Ltda } \\
\text { Irmãos Trevisan S/A Ind. Com. Agric. } \\
\text { Irmãoes Zanetti Ltda } \\
\text { SADIA Concordia S.A. } \\
\text { Mauricio Litvin \& Filhos Ltda } \\
\text { Mocrima - Ind. e Com. Agro-Pecuário Ltda } \\
\text { Moinho 15 de Novembro Ltda } \\
\text { Moinho Brasil Ltda } \\
\text { Moinho Central Caxiense Ltda }\end{array}$ & $\begin{array}{l}\text { Santa Maria - RS } \\
\text { Cruz Alta - RS } \\
\text { Santa Maria - RS } \\
\text { Passo Fundo - RS } \\
\text { Cachoeira do Sul - RS } \\
\text { Faxinal do Sotur. - RS } \\
\text { Cerro Largo - RS } \\
\text { Girua - RS } \\
\text { São Sepé - RS } \\
\text { Tapejara - RS } \\
\text { Garibaldi - RS } \\
\text { Nova Prata - RS } \\
\text { São João Polesine-RS } \\
\text { São Marcos - RS } \\
\text { Caxias do Sul -RS } \\
\text { Ipe - RS } \\
\text { Santa Rosa - RS } \\
\text { Carlos Barbosa - RS } \\
\text { Estação - RS } \\
\text { Julio de Castilhos -RS } \\
\text { Tapejara - RS } \\
\text { Erechim - RS } \\
\text { Palm. das Missões-RS } \\
\text { Santo Angelo - RS } \\
\text { Ijui - RS } \\
\text { Caxias do Sul - RS } \\
\text { Pejuçara - RS } \\
\text { Boq. do Leão - RS } \\
\text { Canoas - RS } \\
\text { Camaquã - RS } \\
\text { Guar. das Missões -RS } \\
\text { Lajeado - RS } \\
\text { Tenente Portela - RS } \\
\text { Nova Araçá - RS } \\
\text { Pinhal - RS } \\
\text { Cachoeira do Sul - RS } \\
\text { Vila Maria - RS } \\
\text { Marcelino Ramos -RS } \\
\text { Erechim - RS } \\
\text { Planalto - RS } \\
\text { Ibirubá - RS } \\
\text { Encantado - RS } \\
\text { Caxias do Sul - RS }\end{array}$ \\
\hline
\end{tabular}


J. Macedo Alimentos S.A.

Moinho do Nordeste S.A.

Moinho Estrela Ltda

Moinho Popular S.A

Moinho São Jeronimo Ltda

Moinho São Nicolau S.A. Ind. e Comércio

Moinho São Pedro S.A.

Moinho Taquariense S.A.

Moinho Tigre Ltda

Moinho Tomazzoni Ltda

Moinho Vacaria Industrial e Agrícola Ltda

Moinho Vicato Indústria e Comércio Ltda

Pena Branca Alimentos S.A.

Moinhos de Trigo Indigena S.A. - Motrisa

Moinhos do Sul S.A. Ind. e Comércio

Moinhos Galopolis S.A

Moinhos Garota S.A.

Moinhos Germani S.A.

Moinhos Guarany S.A.

Moinhos Prifal Ltda

Moinho Forqueta Itda

Sangalli, Busa S/A Ind. e Agropecuária

Santista Alimentos S.A.

Spido \& Cia Ltda

Stella \& Cia Ltda

Tillmann S/A Indústria e Comércio Imob.

Tondo S.A.

Uggeri S.A.

Alessio \& Cia Ltda

Cerealista Marx Ltda

Comercial e Industrial Antonio Viel Ltda

Comércio e Indústria Schadeck S.A.

Coop. Agr. Mista Reg. Pindorama Ltda

Cooperativa Agr. São Miguel do Oeste Itda

Coop. de Prod. e Consumo Concórdia Ltda

Coop. Regional Agrop. de Campos Novos

Cooperativa Regional Alfa Ltda

Cooperativa Regional Auriverde Ltda

Coop. Triticola Rio do Peixe Ltda

Ernesto Piazza e filhos ltda

Fuganti S.A. Indústria e Comércio

Indústria de Farinha Tozzo Ltda

Industrial Aurora Ltda

Industrial Moageira Ltda

Irmãos Lazzarotto Ltda

Irmãos Letti \& Cia Ltda

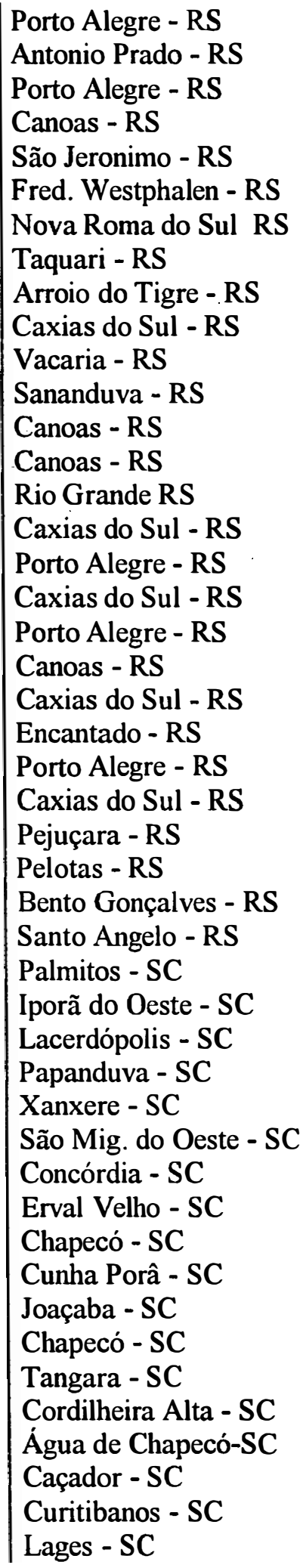




\section{ANEXO 3 (CONT)}

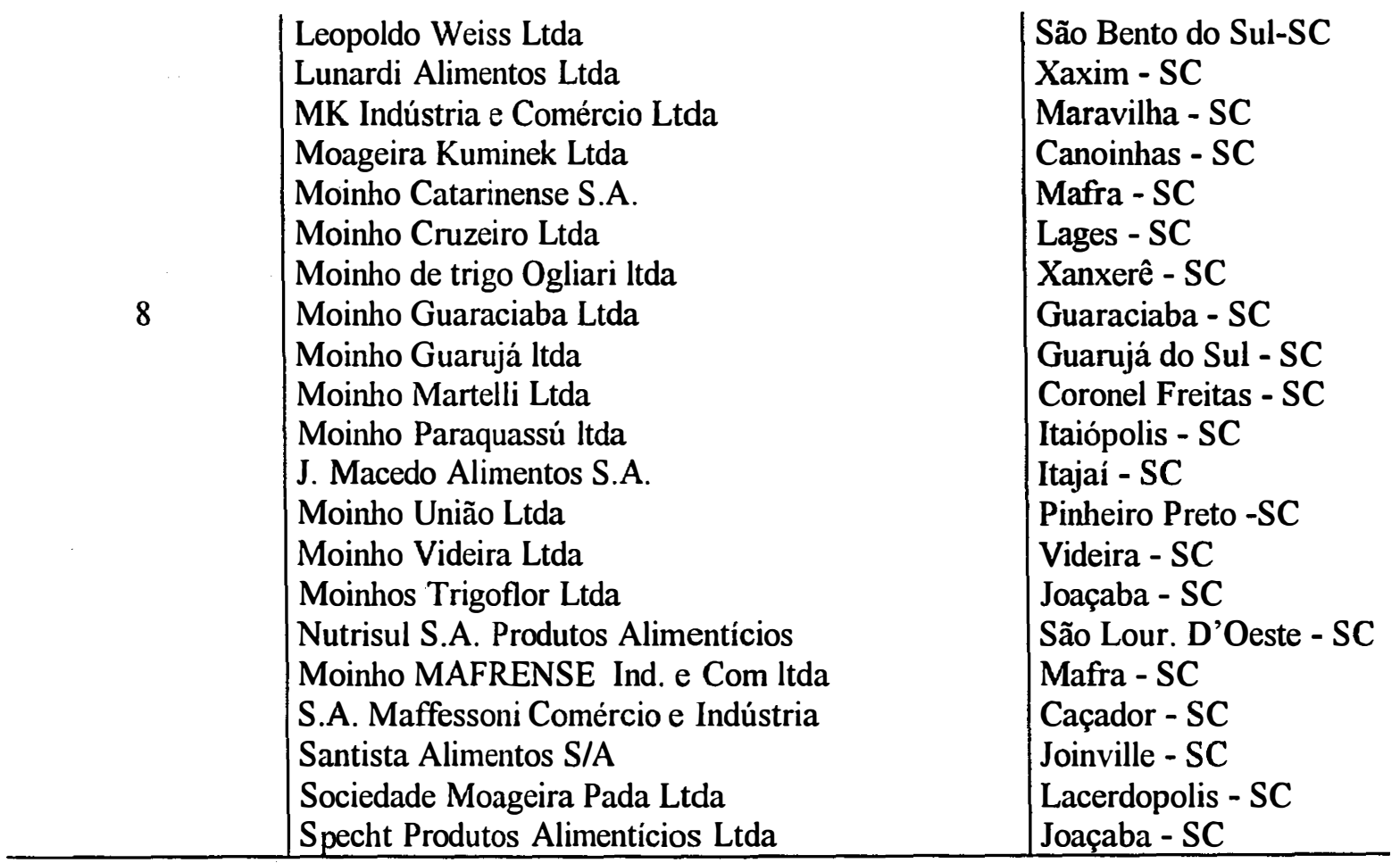

\section{Fonte: ABITRIGO (1996)}

\section{OBSERVAÇÕES:}

1: A Santista alimentos S. A. assinou em novembro de 1996, promessa de compra desta unidade (Jornal Folha de Londrina de $14 / 11 / 1996$ ).

2: Arrendado a Santista Alimentos S.A. do grupo Bunge Brasil. Atualmente com as atividades paralisadas (informações da pesquisa).

3: Atividades paralisadas (informações da pesquisa).

4: Arrendado a Santista Alimentos S.A (informações da pesquisa). 
ANEXO 4: Relação de moinhos brasileiros, por regiões, 1996

\begin{tabular}{|c|c|c|}
\hline Regiões & Moinhos & Cidade/Estado \\
\hline Norte & $\begin{array}{l}\text { Indústria Moageira de Trigo Amazonas S.A. } \\
\text { Pena Branca Alimentos S.A. } \\
\text { Ocrim S.A. Produtos Alimentícios } \\
\text { Pena Branca Alimentos S.A. } \\
\end{array}$ & $\begin{array}{l}\text { Manaus - AM } \\
\text { São Luis - MA } \\
\text { Belém - PA } \\
\text { Belém - PA } \\
\end{array}$ \\
\hline Nordeste & $\begin{array}{l}\text { Empresa Coml. e Indl. de Prod. Vegetais Ltda } \\
\text { Grande Moinho Cearense S.A } \\
\text { J. Macedo Alimentos S.A } \\
\text { Santista Alimentos S.A. } \\
\text { Companhia Produtos Pilar } \\
\text { Pena Branca Alimentos S/A } \\
\text { Santista Alimentos S.A. } \\
\text { Santista Alimentos S.A. } \\
\text { J. Macedo Alimentos S.A. } \\
\text { Moinho Motrisa S/A } \\
\text { Ideal Alimentos Ltda' } \\
\text { J. Macedo Alimentos S.A. } \\
\text { S.A. Moinho da Bahia } \\
\text { Moinho Sergipe S.A. }\end{array}$ & $\begin{array}{l}\text { Fortaleza - CE } \\
\text { Fortaleza - CE } \\
\text { Fortaleza - CE } \\
\text { Cabedelo - PB } \\
\text { Recife - PE } \\
\text { Olinda - PE } \\
\text { Recife - PE } \\
\text { Natal - RN } \\
\text { Maceió - AL } \\
\text { Maceió - AL } \\
\text { Ilhéus - BA } \\
\text { Salvador - BA } \\
\text { Salvador - BA } \\
\text { Aracaju - SE } \\
\end{array}$ \\
\hline Centro-Oeste & $\begin{array}{l}\text { Moinho Sete Irmãos Itda } \\
\text { Domingos Costa Ind. Alimentícias S/A } \\
\text { Indústria Mineira de Moagem S.A. } \\
\text { Moinho Sul Mineiro S.A. } \\
\text { Moinhos Vera Cruz S.A. } \\
\text { Moinhos Vera Cruz S.A. } \\
\text { Companhia Jauense Industrial } \\
\text { EMEGE Produtos Alimenticios S.A. } \\
\text { Arno Werner Máquinas e Motores Ltda } \\
\text { Moinho Campo Grande Itda } \\
\text { Cerealista e Moinho Dallas Ltda } \\
\text { Cerealista e Moinho Dallas Ltda }\end{array}$ & \begin{tabular}{|l|} 
Uberlândia - MG \\
Contagem - MG \\
Contagem - MG \\
Varginha - MG \\
Juiz de Fora - MG \\
Santa Luzia - MG \\
Brasilia - DF \\
Goiânia - GO \\
Dourados - MS \\
Campo Grande - MS \\
Nova Alv.do Sul-MS \\
Rio Brilhante - MS \\
\end{tabular} \\
\hline Sudeste & $\begin{array}{l}\text { Buaiz S.A. Indústria e Comércio } \\
\text { Indústrias Américo Silva Ltda } \\
\text { Indústrias Reunidas Marilu S/A } \\
\text { J. Macedo Alimentos S.A. } \\
\text { Pena Branca Alimentos S.A. } \\
\text { Santista Alimentos S.A. } \\
\text { Anaconda Indl. e Agrícola de Cereais S/A } \\
\text { Braswey S.A. - Indútria e Comércio } \\
\text { Indústrias Reunidas São Jorge S/A } \\
\text { Lapa Alimentos S.A } \\
\text { Lapa Alimentos S.A } \\
\text { Moinho Água Branca S.A. }\end{array}$ & \begin{tabular}{|l|} 
Vitória - ES \\
Três Rios - RJ \\
Rio de Janeiro - RJ \\
Niterói - RJ \\
Rio de Janeiro - RJ \\
Rio de Janeiro - RJ \\
São Paulo - SP \\
Campinas - SP \\
São Paulo - SP \\
Santos - SP \\
São Paulo - SP \\
São Paulo - SP
\end{tabular} \\
\hline
\end{tabular}




\section{ANEXO 4 (CONT)}

\begin{tabular}{|c|c|c|}
\hline Sudeste & $\begin{array}{l}\text { Moinho de Trigo Santo André S.A. } \\
\text { Plus Vita S.A. } \\
\text { Moinho Jundiai S.A. } \\
\text { Moinho Pacifico Ind. e Comércio Ltda } \\
\text { Moinho Paulista Ltda } \\
\text { Moinho Reisa Ltda } \\
\text { Ocrim S.A. Produtos Alimentícios } \\
\text { Ocrim S.A. Produtos Alimentícios } \\
\text { Pastificio Selmi S.A. } \\
\text { Pena Branca Alimentos S/A } \\
\text { Richard Saigh Indústria e Comércio S.A. } \\
\text { Santa Cruz S/A Adm. Merc. e Industrial } \\
\text { Santista Alimentos S.A. } \\
\text { São Valentin Agro-Industrial Ltda } \\
\end{array}$ & \begin{tabular}{|l} 
Santo André - SP \\
Santo André - SP \\
Jundiaí - SP \\
São Paulo SP \\
Santos - SP \\
Guarulhos - SP \\
São Paulo - SP \\
Nova Odessa - SP \\
Campinas - SP \\
São Paulo - SP \\
São Paulo - SP \\
São Paulo - SP \\
Santos - SP \\
Tatuí - SP \\
\end{tabular} \\
\hline Sul & $\begin{array}{l}\text { Ana Clara Indústria de Farinhas Ltda } \\
\text { Anaconda Ind. e Agricola de Cereais S/A } \\
\text { Badotti Agro-Industrial do Paraná Ltda } \\
\text { Cooper. Agraria Mista Entre Rios Ltda } \\
\text { Cooper. Agrop. Mista Laranjeiras do Sul } \\
\text { Cooper. Agropecuária Mourãoense Ltda } \\
\text { Cooperativa Central Regional Iguaçu Ltda } \\
\text { Indústria de Alimentos Tradição Ltda } \\
\text { Indústria e Comércio de Trigo Mariópolis } \\
\text { Indústria Moageira Cidade Alta Ltda } \\
\text { Irmãos Massignan \& Cia Ltda } \\
\text { Miguel Lesnioviski Trigo } \\
\text { Moinho Agrícola Horizonte Ltda } \\
\text { Moinho Boa Vista Ltda } \\
\text { Moinho Bom Sucesso Ltda } \\
\text { Moinho Carlos Guth Ltda } \\
\text { Moinho Curitibano S.A². } \\
\text { Moinho Dallagnoll Ltda } \\
\text { Moinho de Trigo 2 N Ltda } \\
\text { Moinho de Trigo Arapongas Ltda } \\
\text { MOESTEL-Moinho de Trigo Oeste Ind. Com. Itda } \\
\text { Moinho de Trigo Fabulla Ltda } \\
\text { Moinho de Trigo Pontagrossense Ltda } \\
\text { Moinho de Trigo Rotta Ltda } \\
\text { Moinho Globo Indústria e Comércio Ltda } \\
\text { Moinho Graciosa Ltda } \\
\text { Moinho Henke Ltda } \\
\text { Moinho Itaipú S/A } \\
\text { J. Macedo Alimentos S.A. } \\
\text { Moinho Ouro Branco Ltda } \\
\text { Moinho São Luiz Ltda } \\
\text { Moinho Tupy Ltda }\end{array}$ & $\begin{array}{l}\text { Itambé - PR } \\
\text { Curitiba - PR } \\
\text { Cascavel - PR } \\
\text { Guarapuava - PR } \\
\text { Laranj. do Sul - PR } \\
\text { Campo Mourão - PR } \\
\text { Palotina - PR } \\
\text { Cascavel - PR } \\
\text { Mariópolis - PR } \\
\text { Apucarana - PR } \\
\text { Pinhais - PR } \\
\text { Contenda - PR } \\
\text { Mal. C.Rondon - PR } \\
\text { Pien - PR } \\
\text { Bom Suc.do Sul - PR } \\
\text { Curitiba - PR } \\
\text { Curitiba - PR } \\
\text { Cap. L. Marques - PR } \\
\text { Ivaiporã - PR } \\
\text { Arapongas - PR } \\
\text { Pato Branco - PR } \\
\text { Japura - PR } \\
\text { Ponta Grossa - PR } \\
\text { Matelândia - PR } \\
\text { Sertanópolis - PR } \\
\text { Curitiba - PR } \\
\text { Mal. C.Rondon - PR } \\
\text { S.Terez.do Itaipú-PR } \\
\text { Londrina - PR } \\
\text { Santa Fé - PR } \\
\text { Guarapuava - PR } \\
\text { União da Vitória - PR }\end{array}$ \\
\hline
\end{tabular}




\section{ANEXO 4 (CONT)}

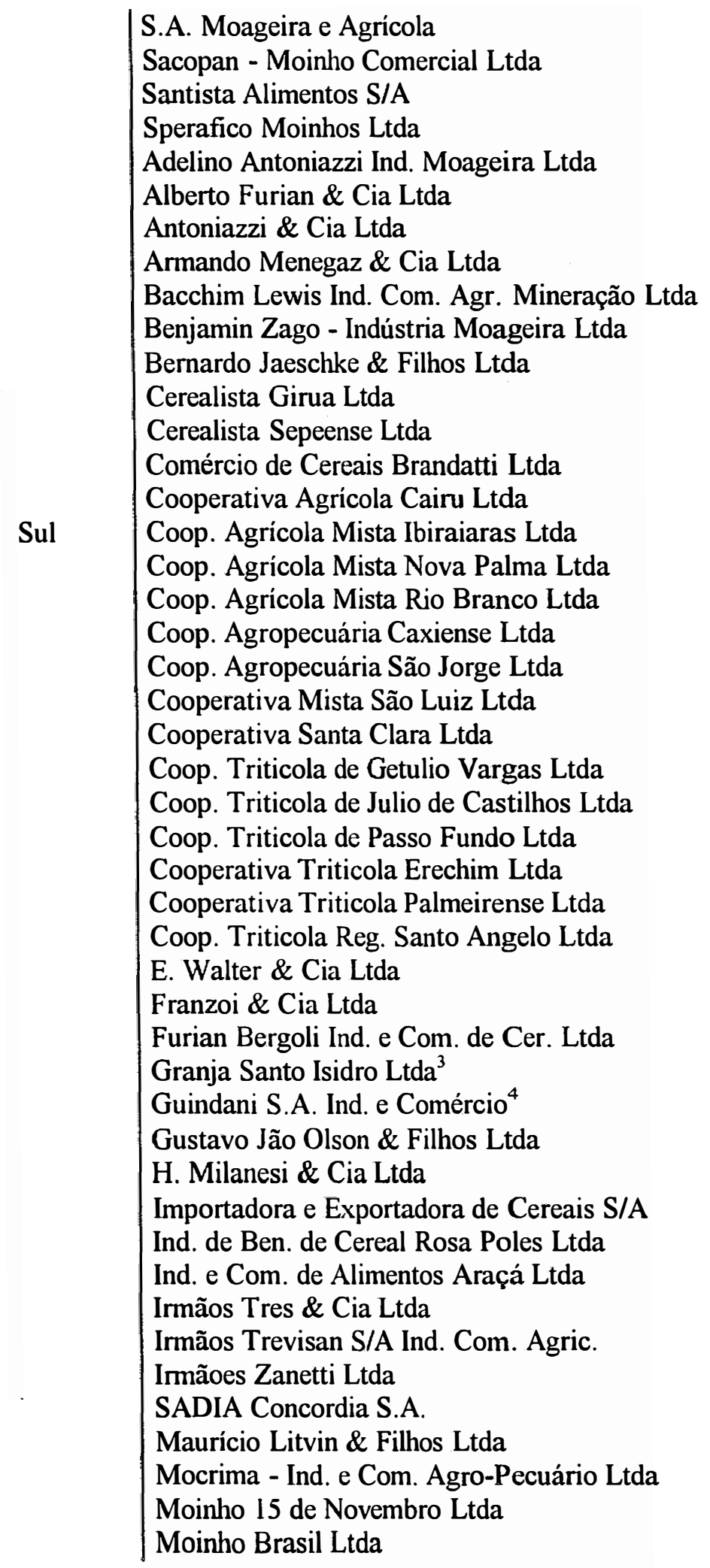

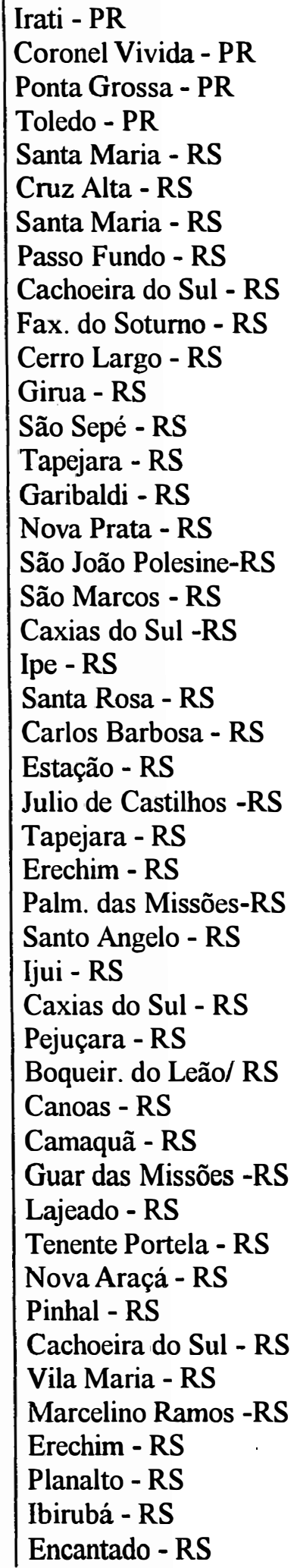




\section{ANEXO 4 (CONT)}

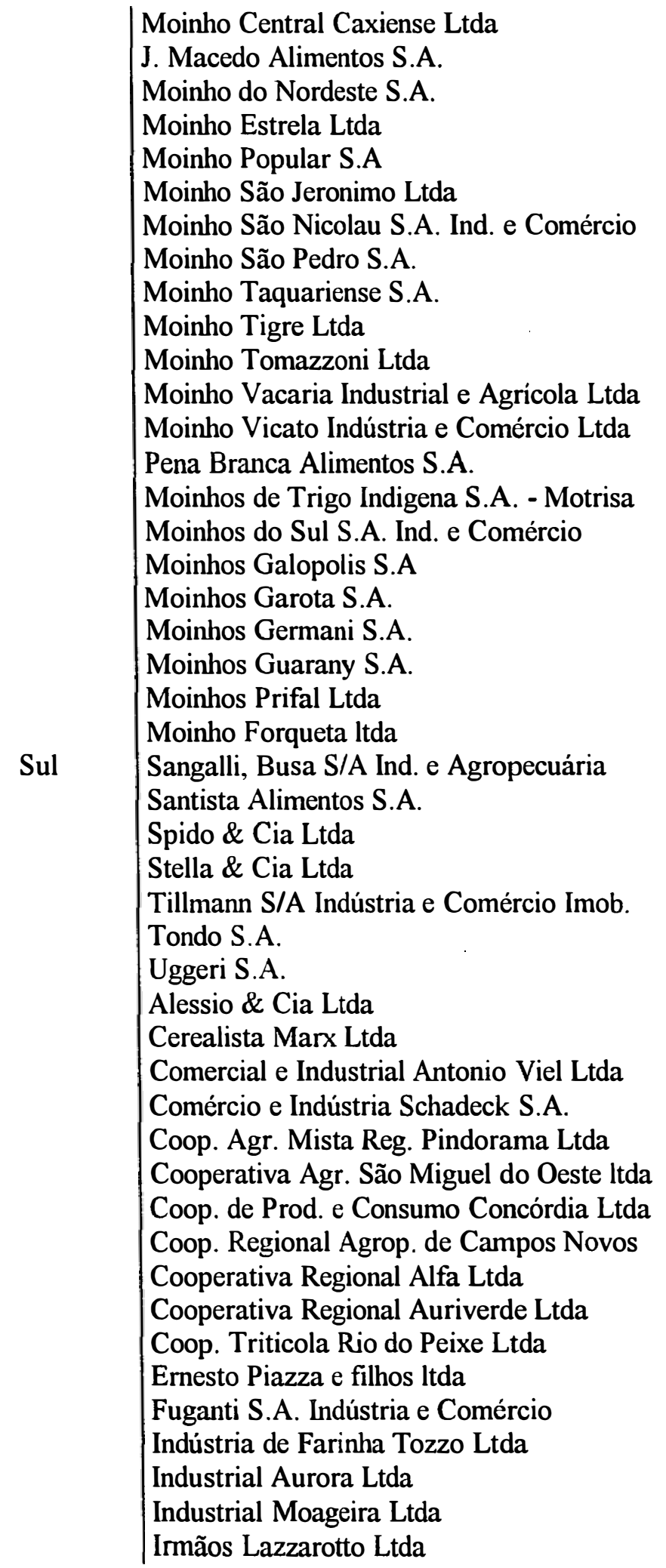

Caxias do Sul - RS

Porto Alegre - RS

Antonio Prado - RS

Porto Alegre - RS

Canoas - RS

São Jeronimo - RS

Fred. Westphalen/ RS

Nova Roma /RS

Taquari - RS

Arroio do Tigre - RS

Caxias do Sul - RS

Vacaria - RS

Sananduva - RS

Canoas - RS

Canoas - RS

Rio Grande RS

Caxias do Sul - RS

Porto Alegre - RS

Caxias do Sul - RS

Porto Alegre - RS

Canoas - RS

Caxias do Sul - RS

Encantado - RS

Porto Alegre - RS

Caxias do Sul - RS

Pejuçara - RS

Pelotas - RS

Bento Gonçalves - RS

Santo Angelo - RS

Palmitos - SC

Iporã do Oeste - SC

Lacerdópolis - SC

Papanduva - SC

Xanxere - SC

São Mig. do Oeste/SC

Concórdia - SC

Erval Velho - SC

Chapecó - SC

Cunha Porâ - SC

Joaçaba - SC

Chapecó - SC

Tangara - SC

Cordilheira Alta - SC

Água de Chapecó-SC

Caçador - SC

Curitibanos - SC 


\section{ANEXO 4 (CONT)}

\begin{tabular}{|l|l} 
Irmãos Letti \& Cia Ltda & Lages - SC \\
Leopoldo Weiss Ltda & São Bento do Sul-SC \\
Lunardi Alimentos Ltda & Xaxim - SC \\
MK Indústria e Comércio Ltda & Maravilha - SC \\
Moageira Kuminek Ltda & Canoinhas - SC \\
Moinho Catarinense S.A. & Mafra - SC \\
Moinho de trigo Ogliari ltda & Lages - SC \\
Moinho Guaraciaba Ltda & Xanxerê - SC \\
Moinho Guarujá ltda & Guaraciaba - SC \\
Moinho Martelli Ltda & Guarujá do Sul - SC \\
Moinho Paraquassú Itda & Coronel Freitas - SC \\
J. Macedo Alimentos S.A. & Itaiópolis - SC \\
Moinho União Ltda & Itajaí - SC \\
Moinho Videira Ltda & Pinheiro Preto -SC \\
Moinhos Trigoflor Ltda & Videira - SC \\
Nutrisul S.A. Produtos Alimentícios & Joaçaba - SC \\
Moinho MAFRENSE Ind. e Com Itda & São L.. D’Oeste/SC \\
S.A. Maffessoni Comércio e Indústria & Mafra - SC \\
Santista Alimentos S/A & Caçador - SC \\
Sociedade Moageira Pada Ltda & Joinville - SC \\
Specht Produtos Alimentícios Ltda & Lacerdopolis - SC \\
\end{tabular}

Fonte: ABITRIGO (1996)

A Cooperativa tritícola de Rosário do Sul não consta desta relação por estar com suas atividades de moagem paralizadas (Dados da pesquisa - agosto de 1996)

OBSERVAÇÕES:

1: A Santista alimentos S. A. assinou em novembro de 1996, promessa de compra desta unidade (Jornal Folha de Londrina de $14 / 11 / 1996)$.

2: Arrendado a Santista Alimentos S.A. do grupo Bunge Brasil. Atualmente com as atividades paralisadas (informações da pesquisa).

3: Atividades paralisadas (informações da pesquisa).

4: Arrendado a Santista Alimentos S.A (informações da pesquisa). 
ANEXO 5: Moinhos pertencentes a cooperativas de produtores, por estado - Brasil (1996)

\begin{tabular}{|c|c|c|}
\hline Estado & \begin{tabular}{|c|} 
Moinhos \\
\end{tabular} & Cidade/Estado \\
\hline Paraná & $\begin{array}{l}\text { Cooper. Agraria Mista Entre Rios Ltda } \\
\text { Cooper. Agrop. Mista Laranjeiras do Sul } \\
\text { Cooper. Agropecuária Mourãoense Ltda } \\
\text { Cooperativa Central Regional Iguaçu Ltda }\end{array}$ & $\begin{array}{l}\text { Guarapuava - PR } \\
\text { Laranj. do Sul - PR } \\
\text { Campo Mourão - PR } \\
\text { Palotina - PR } \\
\end{array}$ \\
\hline Rio Grande doSul & $\begin{array}{l}\text { Cooperativa Agrícola Cairu Ltda } \\
\text { Coop. Agricola Mista Ibiraiaras Ltda } \\
\text { Coop. Agricola Mista Nova Palma Ltda } \\
\text { Coop. Agricola Mista Rio Branco Ltda } \\
\text { Coop. Agropecuária Caxiense Ltda } \\
\text { Coop. Agropecuária São Jorge Ltda } \\
\text { Cooperativa Mista São Luiz Ltda } \\
\text { Cooperativa Santa Clara Ltda } \\
\text { Coop. Triticola de Getulio Vargas Ltda } \\
\text { Coop. Triticola de Julio de Castilhos Ltda } \\
\text { Coop. Triticola de Passo Fundo Ltda } \\
\text { Cooperativa Triticola Erechim Ltda } \\
\text { Cooperativa Triticola Palmeirense Ltda } \\
\text { Coop. Triticola Reg. Santo Angelo Ltda } \\
\end{array}$ & $\begin{array}{l}\text { Garibaldi - RS } \\
\text { Nova Prata - RS } \\
\text { São João Polesine-RS } \\
\text { São Marcos - RS } \\
\text { Caxias do Sul -RS } \\
\text { Ipe - RS } \\
\text { Santa Rosa - RS } \\
\text { Carlos Barbosa - RS } \\
\text { Estação - RS } \\
\text { Julio de Castilhos -RS } \\
\text { Tapejara - RS } \\
\text { Erechim - RS } \\
\text { Palmeira das Missões -RS } \\
\text { Santo Angelo - RS } \\
\end{array}$ \\
\hline Santa Catarina & $\begin{array}{l}\text { Coop. Agr. Mista Reg. Pindorama Ltda } \\
\text { Coop. de Prod. e Consumo Concordia Ltda } \\
\text { Coop. Regional Agrop. de Campos Novos } \\
\text { Cooperativa Regional Alfa Ltda } \\
\text { Cooperativa Regional Auriverde Ltda } \\
\text { Coop. Triticola Rio do Peixe Ltda }\end{array}$ & $\begin{array}{l}\text { Xanxere - SC } \\
\text { Concordia - SC } \\
\text { Erval Velho - SC } \\
\text { Chapecó - SC } \\
\text { Cunha Porâ - SC } \\
\text { Joaçaba - SC }\end{array}$ \\
\hline
\end{tabular}

Fonte: ABITRIGO (1996)

Obs: A Cooperativa tritícola de Rosário do Sul não consta da relação por estar com suas atividades de moagem paralizadas (Dados da pesquisa - agosto de 1996) 